\title{
MAPEAMENTO DOS TEORES DE ÓLEO E PROTEÍNA DE GRÃOS DE SOJA E ANÁLISE DE SUA CORRELAÇÃO COM ATRIBUTOS DO SOLO
}

\section{FÁBIO DENARI DE OLIVEIRA}

\author{
Dissertação apresentada à Escola Superior de \\ Agricultura "Luiz de Queiroz", Universidade de São \\ Paulo, para obtenção do título de Mestre em \\ Agronomia, Área de Concentração: Máquinas \\ Agrícolas.
}

P I R A C I C A B A

Estado de São Paulo - Brasil

Outubro - 2003 


\title{
MAPEAMENTO DOS TEORES DE ÓLEO E PROTEÍNA DE GRÃOS DE SOJA E ANÁLISE DE SUA CORRELAÇÃO COM ATRIBUTOS DO SOLO
}

\section{FÁBIO DENARI DE OLIVEIRA}

Engenheiro Agrônomo

Orientador: Prof. Dr. LUIZ ANTONIO BALASTREIRE

\begin{abstract}
Dissertação apresentada à Escola Superior de Agricultura "Luiz de Queiroz", Universidade de São Paulo, para obtenção do título de Mestre em Agronomia, Área de Concentração: Máquinas Agrícolas.
\end{abstract}

P I R A C I C A B A

Estado de São Paulo - Brasil

Outubro -2003 


\section{Dados Internacionais de Catalogação na Publicação (CIP) DIVISÃO DE BIBLIOTECA E DOCUMENTAÇÃO - ESALQ/USP}

\section{Oliveira, Fábio Denari}

Mapeamento dos teores de óleo e proteína de grãos de soja e análise de sua correlação com atributos do solo / Fábio Denari de Oliveira. - - Piracicaba, 2003.

115 p. : il.

Dissertação (mestrado) - - Escola Superior de Agricultura Luiz de Queiroz, 2003. Bibliografia.

1. Grão de soja 2. Mapeamento 3. Propriedade físico-química do solo 4. Teor de óleo 5. Teor protéico 6. Variabilidade espacial I. Título

CDD 633.34

"Permitida a cópia total ou parcial deste documento, desde que citada a fonte - $O$ autor" 


\section{AGRADECIMENTOS}

A Deus, pela vida e pela saúde.

Ao Professor Dr. Luiz Antonio Balastreire, pela oportunidade, orientação e confiança em mim depositada.

Aos Professores Drs. Tomaz C. Rípoli e Marcos Milan e de outros Departamentos que contribuíram para a minha formação e enriquecimento profissional.

A todos os funcionários do Departamento de Engenharia Rural, em especial ao Juarez Renó Amaral, pelo apoio e informações oferecidos durante o curso.

Aos amigos Fábio H. Rojo Baio e Júlio César D. M. Esquerdo, pelo apoio, amizade e colaboração.

Aos irmãos José, Alberto, Humberto e Tomaz Ludowig, por terem cedido a área para realização deste trabalho.

À Cooperativa Agrícola Sul Brasil da Alta Sorocabana, por ter-me liberado

para fazer este curso, sua diretoria, cooperados e funcionários pela paciência e colaboração.

À Faculdade de Ciências Agrárias da Unoeste, de Presidente Prudente - SP, por ter realizado as análises químicas e físicas de solo e bromatológicas dos grãos de soja.

Ao amigo Nelson Tomio Yamashita da empresa Mitsui Fertilizantes S/A, pela ajuda na escolha da área deste trabalho.

Ao Professor Edílson Ferreira Flores da UNESP de Presidente Prudente, pelas sugestões fornecidas.

Ao Professor Paulo Milton Barbosa Landim, da UNESP de Rio Claro, pelo apoio nas dificuldades relacionadas à geoestatística. 
A meus pais e meu irmão, pelo incentivo.

Finalmente, à minha esposa Célia e ao meu filho Pedro, pelo incentivo e paciência. 


\section{SUMÁRIO}

\begin{tabular}{|c|c|c|}
\hline & & Página \\
\hline STA & DE ABREVIATURAS E SÍMBOLOS.. & viii \\
\hline RESUN & MO & xiii \\
\hline SUMM & MARY. & $\mathrm{xv}$ \\
\hline 1 & 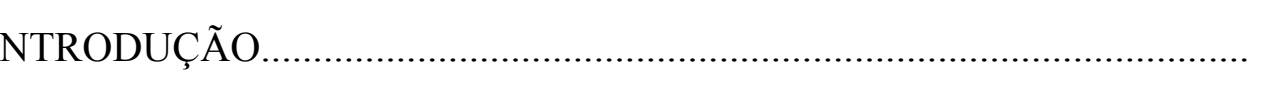 & 1 \\
\hline $\mathrm{Rl}$ & REVISÃO DE LITERATURA.................. & 3 \\
\hline 2.1 & Variabilidade espacial dos atributos da soja..... & 3 \\
\hline 2.2 & 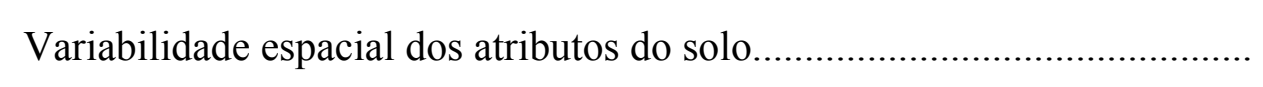 & 5 \\
\hline 2.2 .1 & A estatística no estudo da variabilidade de solos... & 6 \\
\hline 2.2 .2 & A amostragem do solo......... & 7 \\
\hline 2.3 & 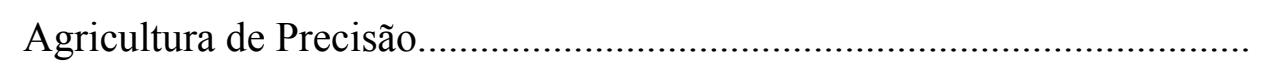 & 8 \\
\hline 2.3 .1 & Sistema de Posicionamento Global - GPS... & 9 \\
\hline 2.3 .2 & Erros do GPS....... & 11 \\
\hline 2.3 .3 & A correção diferencial do GPS (DGPS) ................. & 11 \\
\hline 2.3 .4 & Sistema de Informações Geográficas - SIG.. & 13 \\
\hline 2.4 & A estatística no estudo da variabilidade........ & 16 \\
\hline 2.4 .1 & 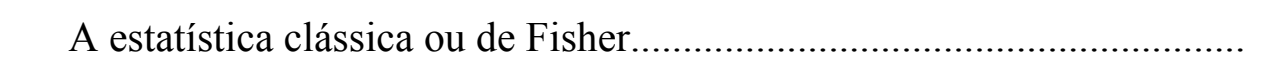 & 16 \\
\hline 2.4 .2 & A análise exploratória de dados.......................... & 20 \\
\hline 2.4 .3 & Geoestatística ou a teoria das variáveis regionalizadas..... & 21 \\
\hline 2.4 .4 & O variograma..... & 23 \\
\hline 2.4.4.1 & Parâmetros do semivariograma...... & 25 \\
\hline 2.4.4.2 & Modelos teóricos de semivariograma.... & 27 \\
\hline 2.4.4.3 & 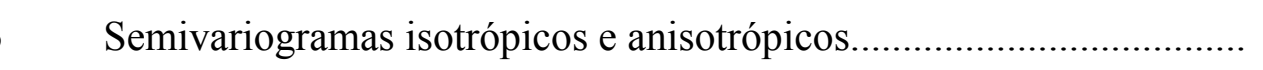 & 32 \\
\hline
\end{tabular}


2.4.4.4 Cálculo do semivariograma a partir de amostras regularmente espaçadas............................................................................... 36

2.4.4.5 Cálculo do semivariograma a partir de amostras irregularmente

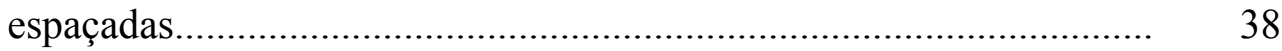

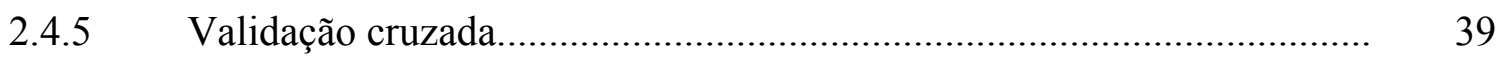

2.4.6 Interpolação por krigagem........................................................... 40

2.4.7 Krigagem ordinária em blocos..................................................... 41

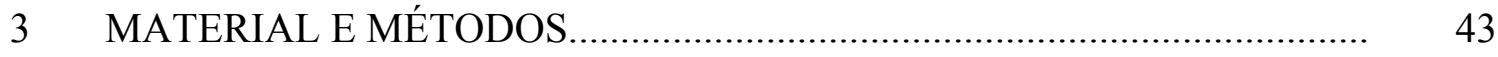

3.1 Caracterização da área experimental..................................................... 43

3.2 Esquema experimental de amostragem da soja e do solo.......................... 46

3.3 Sistema de Posicionamento Global - GPS.......................................... 49

$3.4 \quad$ Programas computacionais.............................................................. 50

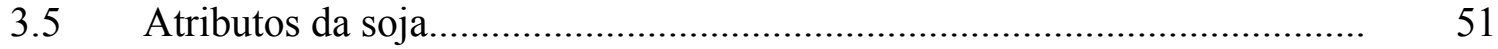

3.5.1 Análise da porcentagem do extrato etéreo na matéria seca (\%E.E. MS)

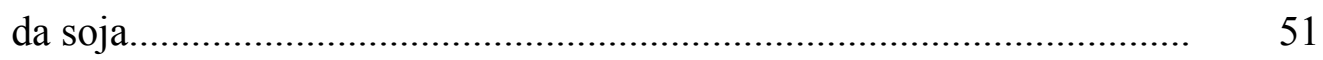

3.5.2 Análise da porcentagem da proteína bruta na matéria seca (\%P.B. MS)

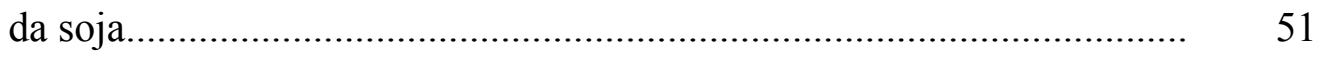

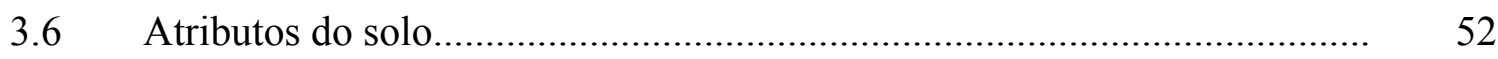

3.6.1 Análise de fertilidade.................................................................. 52

3.6.2 Análise granulométrica............................................................. 53

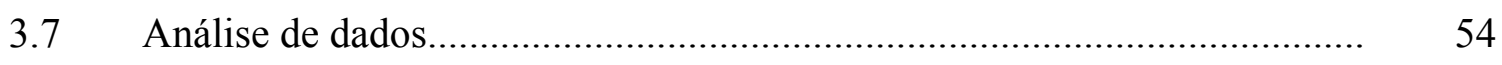

3.7.1 Análise estatística dos dados amostrados....................................... 54

3.7.2 Análise de regressão linear múltipla................................................ 55

3.7.3 Análise geoestatística dos dados amostrados..................................... 56

3.7.3.1 Interpolação dos dados amostrados................................................. 57

$4 \quad$ RESULTADOS E DISCUSSÃO............................................................ 59

4.1 Análises descritivas e exploratórias................................................... 59

4.2 Análise de regressão linear múltipla...................................................... 70

4.3 Análise geoestatística dos dados amostrados........................................ 73

4.3.1 Semivariograma e mapas dos atributos da soja e do solo...................... 75 


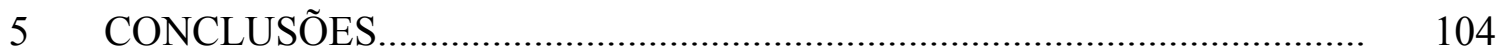

REFERÊNCIAS BIBLIOGRÁFICAS......................................................... 105 


\section{LISTA DE ABREVIATURAS E SÍMBOLOS}

$\alpha_{i}=$ Constantes desconhecidas a serem determinadas.

$\sum_{i=1}^{n} \lambda_{i}=$ Média dos pesos correspondentes aos valores $x_{i}$ na vizinhança do bloco.

$\mu_{V}=$ Parâmetro de Lagrangian associado à minimização.

\%E.E.M.S. (\%) = Porcentagem de Extrato Etéreo na Matéria Seca (óleo).

\%P.B.M.S. $(\%)$ = Porcentagem de Proteína Bruta na Matéria Seca (proteína).

$2 \gamma(h)=$ Variograma.

$2 \hat{\gamma}(h)=$ Variograma estimado.

$\sigma_{V}^{2}=$ Variância de estimativa mínima para o bloco $V$.

$\mathrm{a}(\mathrm{m})=$ Alcance do semivariograma.

$\mathrm{a}_{1}=$ Alcance na direção de maior continuidade.

$\mathrm{a}_{2}=$ Alcance na direção de menor continuidade.

$a_{3}=$ Índice de assimetria.

$\mathrm{A}=$ Amplitude dos dados.

$\mathrm{AI}=$ Amplitude Interquartil.

$\mathrm{Al}\left(\mathrm{mmolc} . \mathrm{dm}^{-3}\right)=$ Alumínio.

A.O.A.C. $=$ Association of Official Agricultural Chemists.

$\mathrm{A} / \mathrm{s}=$ Amplitude total dos dados (A) sobre o Desvio padrão (s).

B $\left(\mathrm{mg} \cdot \mathrm{dm}^{-3}\right)=$ Boro.

$C_{r}=$ Coeficiente de curtose.

$\mathrm{C}_{\mathrm{s}}=$ Coeficiente de assimetria. 
$\mathrm{C}_{1}=$ Contribuição (Diferença entre Patamar "C" e o Efeito pepita " $\mathrm{C}_{0}$ ").

CAAP $=$ Centro Australiano para Agricultura de Precisão.

$\mathrm{C} / \mathrm{A}=$ Coarse/Aquisition.

Ca $\left(\right.$ mmolc.dm $\left.{ }^{-3}\right)=$ Cálcio.

$\mathrm{C} / \mathrm{N}=$ Relação de carbono sobre nitrogênio.

Co $=$ Efeito pepita do semivariograma.

$\mathrm{Co} / \mathrm{Co}+\mathrm{C}(\%)=$ Relação entre efeito pepita e patamar.

$\mathrm{Co}+\mathrm{C}=$ Patamar do semivariograma.

$\mathrm{CO}_{2}=$ Gás carbônico.

CTC $\left(\right.$ mmolc. $\left.\mathrm{dm}^{-3}\right)=$ Capacidade de Troca de Cátions.

$\mathrm{Cu}\left(\mathrm{mg} \cdot \mathrm{dm}^{-3}\right)=$ Cobre.

CV $(\%)=$ Coeficiente de variação.

$\mathrm{d}=$ Distância entre dois pontos consecutivos.

DGPS $=$ Differential Global Positioning System.

DXF $=$ Extensão para trabalhar com planilhas eletrônicas.

$\varepsilon_{\mathrm{i}}=$ Representa toda a fonte de variabilidade em "y" não explicada por "x".

EUA $=$ Estados Unidos da América.

Fe $\left(\mathrm{mg} \cdot \mathrm{dm}^{-3}\right)=$ Ferro.

FTE BR-12 = Adubo formulado com micronutrientes $(\mathrm{Zn}=9,00 \% ; \mathrm{B}=1,80 \% ; \mathrm{Cu}=$ $0,80 \% ; \mathrm{Fe}=3,00 \% ; \mathrm{Mn}=2,00 \%$ e $\mathrm{Mo}=0,10 \%)$.

GPS $=$ Sistema de Posicionamento Global (Global Positioning System).

GRD = Extensão do arquivo gerado da interpolação por krigagem pelo programa GS+.

$\mathrm{h}=$ Vetor que separa dois pontos amostrais.

ha $=$ Hectare.

$\mathrm{H}+\mathrm{Al}\left(\right.$ mmolc.dm $\left.{ }^{-3}\right)=$ Acidez potencial.

$\mathrm{H}_{2} \mathrm{O}=$ Água.

$\mathrm{H}_{2} \mathrm{PO}_{4}^{-}=$Forma iônica de fosfato.

HAE = Altura acima do elipsóide.

$\mathrm{K}\left(\mathrm{mmolc} \cdot \mathrm{dm}^{-3}\right)=$ Potássio. 
lag = Classe de distância do variograma.

$\mathrm{LI}=$ Limite Inferior.

LS = Limite Superior.

$\mathrm{m}=$ metro.

$\mathrm{m} \%=$ Porcentagem de saturação por alumínio.

$M_{0}=$ Moda.

$M_{3}=$ Momento de $3^{\mathrm{a}}$ ordem.

$M_{4}=$ Momento de $4^{\mathrm{a}}$ ordem.

Mercosul $=$ Mercado Comum do Sul.

$\mathrm{Mg}\left(\mathrm{mmolc} \cdot \mathrm{dm}^{-3}\right)=$ Magnésio.

$\operatorname{Mn}\left(\mathrm{mg} \cdot \mathrm{dm}^{-3}\right)=$ Manganês.

M.O. $\left(\right.$ g. $\left.\mathrm{dm}^{-3}\right)=$ Matéria Orgânica.

$n=$ Tamanho da amostra.

$\mathrm{N}=$ Nitrogênio.

$N=$ Tamanho da amostra.

$\mathrm{N}(\mathrm{h})=$ Número de partes de valores medidos, $\mathrm{z}(\mathrm{xi})$ e $\mathrm{z}(\mathrm{xi}+\mathrm{h})$, separados por um vetor distância h.

$\mathrm{Na}=$ Sódio.

NAVSTAR $=$ Navigation Satellite with Time and Ranging.

$\mathrm{NH}_{3}=$ Amônia.

$\mathrm{NH}_{4}^{+}=$Amônio.

$\mathrm{NO}_{3}{ }^{-}=$Forma iônica de nitrato.

$\mathrm{P}\left(\mathrm{mg} \cdot \mathrm{dm}^{-3}\right)=$ Fósforo.

PDI $=$ Sistemas de processamento digital de imagens.

QI = Quartis Inferior.

QS = Quartis Superior.

$r^{2}(\%)=$ Coeficiente de determinação (Modelo de regressão linear múltipla).

$r^{2}(\%)=$ Ajuste do modelo variográfico ao variograma experimental (Gráfico do semivariograma). 
$\mathrm{R}^{2}(\%)=$ Ajuste da validação cruzada.

$s=$ Desvio padrão.

$s_{3}=$ Desvio padrão elevado ao cubo.

$s_{4}=$ Quadrado da variância.

$S=$ Desvio padrão.

$\mathrm{S}\left(\mathrm{mg} \cdot \mathrm{dm}^{-3}\right)=$ Enxofre.

$S^{2}=$ Variância.

$\mathrm{SA}=$ Selective Availability (Disponibilidade Seletiva).

$\mathrm{SB}\left(\right.$ mmolc. $\left.\mathrm{dm}^{-3}\right)=$ Soma de Bases.

SGDF $=$ Sistema de gerenciamento de banco de dados.

$\mathrm{SIG}=$ Sistema de Informações Geográficas.

$\mathrm{SO}_{4}{ }^{2-}=$ Forma iônica de sulfato.

Unoeste $=$ Universidade do Oeste Paulista (Presidente Prudente - SP).

USDA = Departamento de Agricultura dos Estados Unidos.

UTM = Universal Transverso de Mercator.

$\mathrm{V} \%=$ Porcentagem de saturação por bases.

WGS-84 = World Geodesic System 1984.

$X_{i}=$ I-ésima observação amostral.

$\bar{X}=$ Média populacional.

$\mathrm{X}_{\text {más }}=$ Valor máximo.

$\mathrm{X}_{\text {mín }}=$ Valor mínimo.

$\hat{\gamma}(h)=$ Semivariância estimado.

$\gamma\left(x_{i}, V\right)=$ Semivariância média entre os pontos amostrais $x_{i}$ na vizinhança e aqueles no bloco $V$.

$\gamma(V, V)=$ Semivariância média entre todos os pontos dentro do bloco $V$ (isto é, a variância dentro do bloco da estatística clássica).

$\mathrm{z}=$ Variável em estudo.

$\mathrm{z}(\mathrm{xi})=$ São valores da i-ésima observação da variável regionalizada, coletados nos 
pontos $\mathrm{x}_{\mathrm{i}}(\mathrm{i}=1, \ldots, \mathrm{n})$.

$\mathrm{z}(\mathrm{xi}+\mathrm{h})=$ São valores da i-ésima observação da variável regionalizada, coletados nos pontos $x_{i}+h(i=1, \ldots, n)$, separado pelo vetor $h$.

$\mathrm{Zn}\left(\mathrm{mg} \cdot \mathrm{dm}^{-3}\right)=$ Zinco. 


\title{
MAPEAMENTO DOS TEORES DE ÓLEO E PROTEÍNA DE GRÃOS DE SOJA E ANÁLISE DE SUA CORRELAÇÃO COM ATRIBUTOS DO SOLO
}

\author{
Autor: FÁBIO DENARI DE OLIVEIRA \\ Orientador: Prof. Dr. LUIZ ANTONIO BALASTREIRE
}

\section{RESUMO}

Este estudo teve como objetivo determinar a variabilidade espacial dos teores de óleo e proteína de grãos de soja e correlacioná-los com atributos do solo. Em uma área aproximada de 9,01ha, foram realizadas 170 coletas de dados em pontos correspondentes aos nós de uma malha regular de $25 \mathrm{~m}$. Em um raio de $1 \mathrm{~m}$ ao redor do ponto central georreferenciado, foram colhidos todos os grãos de soja e coletadas 7 subamostras de solo, totalizando uma amostra composta. A correlação entre dados, visando a explicar a variabilidade espacial da produtividade de culturas agrícolas, é uma das fases mais importantes e sensíveis da Agricultura de Precisão. Muitos são os atributos que podem estar influenciando os teores de óleo (Porcentagem de Extrato Etéreo na Matéria Seca - \%E.E.M.S.) e proteína (Porcentagem de Proteína Bruta na Matéria Seca - \%P.B.M.S.) do grão de soja como, por exemplo, os do solo (compactação, estrutura, nutrientes, textura, umidade), os da planta (nutrientes absorvidos, enraizamento, disponibilidade de água nas folhas, ataque de pragas) e os do 
clima (radiação solar, vento, temperatura e umidade). Com os atributos utilizados neste estudo não houve correlação satisfatória entre a variabilidade espacial dos atributos da fertilidade e textura do solo com teores de óleo (Porcentagem de Extrato Etéreo na Matéria Seca - \%E.E.M.S.) e proteína (Porcentagem de Proteína Bruta na Matéria Seca - \%P.B.M.S.) da soja da área experimental e também um baixo coeficiente de determinação na análise de regressão linear múltipla para as variáveis óleo e proteína. Quanto à análise geoestatística, as variáveis, óleo (Porcentagem de Extrato Etéreo na Matéria Seca - \%E.E.M.S.), proteína (Porcentagem de Proteína Bruta na Matéria Seca \%P.B.M.S.), argila e boro não apresentaram dependência espacial. Na área experimental encontrou-se um ótimo coeficiente de determinação entre as variáveis de atributos do solo (silte, $\mathrm{H}+\mathrm{Al}$, M.O., $\mathrm{Ca}, \mathrm{Mg}, \mathrm{K}, \mathrm{SB}, \mathrm{CTC}, \mathrm{V} \%, \mathrm{Mn} \mathrm{eCu}$ ) todos maior que $85 \%$, apenas a variável $\mathrm{K}$ teve um ajustamento que pode ser considerado bom, ficando entre $75 \%$ e $85 \%$. 


\title{
OIL AND PROTEIN CONTENTS YIELD MAPS AND SOIL ATTRIBUTES CORRELATION ANALYSIS FOR SOYBEAN GRAINS
}

\author{
Author: FÁBIO DENARI DE OLIVEIRA \\ Adviser: Prof. Dr. LUIZ ANTONIO BALASTREIRE
}

\section{SUMMARY}

The purpose of the present study was to determine the spatial variability of oil and protein contents in soybean grains and to correlate these characteristics with soil attributes. In a 9.01ha field, 170 samples were taken at the nodes of a $25 \mathrm{~m}$ regular grid. Within a 1-m radius around the georeferenced node, all soybean grains were collected, as well as 7 soil subsamples, constituting one compound sample. One of the most important and delicate aspects of Precision Agriculture is correlating data to explain the spatial yield variability of agricultural crops. There are several attributes that can influence oil (percentage of ethereal extract in dry matter - \%E.E.D.M.) and protein (percentage of gross protein in dry matter - \%G.P.D.M.) amounts in soybean grains, such as, those related to the soil (compaction, structure, nutrients, texture, moisture), plants (nutrients absorbed, rooting, water availability in the leaves, pest attacks) and climate (solar radiation, wind, temperature and humidity). Considering the attributes studied, poor correlation was verified between the spatial variability of soil fertility and texture with oil (percentage of ethereal extract in dry matter - \%E.E.D.M.) and protein 
(percentage of gross protein in dry matter - \%G.P.D.M.) amounts in soybean grains from the experimental area. A low coefficient of determination for the multiple linear regression analysis was obtained for the attributes oil and protein contents. Using geostatistical analysis, no spatial dependence was verified for the variables oil (ethereal extract in dry matter - \%E.E.D.M.), protein (gross protein in dry matter - \%G.P.D.M.), clay and boron amounts. The soil attributes (silt, H+Al, D.M., Ca, Mg, K, SB, CEC, $\mathrm{V} \%, \mathrm{Mn}$ and $\mathrm{Cu}$ ) showed excellent coefficients of determination in the experimental area, with all coefficients above $85 \%$, except for $\mathrm{K}$, which showed coefficients between $75 \%$ and $85 \%$, which are considered good. 


\section{INTRODUÇÃO}

No decorrer do ano-safra 2002/03 e pela primeira vez na história da agricultura global, a produção conjunta de soja dos países do Mercosul superou a dos Estados Unidos. Segundo relatório de safra do Departamento de Agricultura dos Estados Unidos (USDA), no período considerado, as colheitas do Brasil, Argentina, Paraguai e Bolívia totalizaram 93,44 milhões de toneladas, em contrapartida aos 74,29 milhões de toneladas obtidas nas lavouras norte-americanas.

O Brasil ocupa a posição de segundo maior produtor mundial e desfruta do privilégio de ser o único fornecedor mundial em condições de aumentar substancialmente a oferta da oleaginosa não apenas em função de notáveis ganhos de produtividade, como ocorreu ao longo das últimas três décadas, mas também mediante a incorporação de vastas áreas passíveis de aproveitamento agrícola, sendo atendido o conceito de desenvolvimento sustentável (desenvolvimento econômico planejado com base na utilização de recursos e na implantação de atividades industriais, de forma a não esgotar ou degradar os recursos naturais; ecodesenvolvimento).

A soja constitui a mais importante lavoura do País, tanto na área de cultivo, como no valor agregado de suas colheitas anuais, formando ainda o complexo - grão, farelo e óleo -, considerado o mais relevante setor exportador brasileiro. É digno de nota também o impacto da cadeia do agronegócio da soja sobre os setores de fertilizantes, defensivos, máquinas e implementos agrícolas, em relação aos quais a sojicultura detém a primazia das compras e das encomendas.

Determinando-se a variabilidade da cultura da soja, no que diz respeito aos teores de óleo (Porcentagem de Extrato Etéreo na Matéria Seca - \%E.E.M.S.) e proteína (Porcentagem de Proteína Bruta na Matéria Seca - \%P.B.M.S.), e possíveis correlações 
com as análises físicas e químicas do solo, a Agricultura de Precisão vem facilitar o gerenciamento localizado da cultura, podendo, com isto, tomar decisões do que plantar e onde, em função das necessidades de óleo e proteína.

O trabalho desenvolvido por Lamond \& Wesley (2001) indicou um aumento nas concentrações de óleo e proteína dos grãos de soja com aplicação tardia de nitrogênio suplementar na soja. Por essa razão, espera-se uma correlação dos teores de óleo e proteína da soja com a matéria orgânica do solo, por ela estar associada ao teor de nitrogênio do solo; devido à complexidade das transformações que ocorrem com o nitrogênio no solo, não se obteve até hoje uma metodologia de laboratório capaz de integralizar o grande número de fatores que afetam esses processos e fornecer um índice de disponibilidade de nitrogênio, resolveu-se não fazer a análise de nitrogênio e buscar uma correlação com a matéria orgânica.

O objetivo deste trabalho foi avaliar as relações entre variabilidade espacial das propriedades químicas e físicas do solo e a variabilidade dos atributos da soja (óleo e proteína), para ajudar a identificar a relação de causa e efeito desses atributos. 


\section{REVISÃO DE LITERATURA}

\subsection{Variabilidade espacial dos atributos da soja}

Trangmar et al., 1987; Souza, 1992; Cambardella et al., 1994; Paz et al., 1996; Salviano, 1996, consideram o modelo esférico como o mais adaptado para descrever o comportamento de semivariogramas de atributos de plantas e de solos. Os dados referentes aos atributos de planta apresentam um espalhamento bastante grande em volta do modelo escalonado, indicando que os dados têm variabilidade espacial diferente na área. A análise do efeito pepita dos atributos mostrou que a massa e o "stand" apresentaram melhores dependências espaciais do que as produtividades. Os semivariogramas se ajustam ao modelo esférico, o qual representa fenômenos que têm a maior mudança de dependência espacial com a distância (Vieira et al., 1991).

As relações entre a variabilidade espacial dos atributos do solo e a variabilidade dos atributos de plantas têm sido estudadas, para ajudar a identificar a relação de causa e efeito desses atributos (Vieira et al., 1987; Miller et al., 1988 e Salviano et al., 1998).

Long et al. (1998) discutem uma pesquisa realizada para o mapeamento de proteína para o gerenciamento de precisão de uma cultura de trigo. Esclarecem que os agricultores de Montana (EUA) trabalham em um sistema de pagamento por qualidade que oferece incentivos para maximizar os níveis de proteínas em suas culturas, no intervalo de $13 \%$ a $15 \%$. O mapeamento do teor de proteína nos grãos de trigo foi feito utilizando-se um DGPS com acurácia de posicionamento ao redor de $1 \mathrm{~m}$, para o georreferenciamento de amostras retiradas manualmente do elevador de grãos da 
colhedora utilizada. O teor de proteínas dos grãos foi determinado por um analisador NIR para grãos inteiros. Uma interpolação por krigagem foi feita utilizando-se uma grade com células de $9 \mathrm{~m}$ x 9m, cujos resultados foram colocados em um programa para GIS, o qual foi utilizado para combinar, aritmeticamente, os mapas de produtividade.

Os melhoristas de soja precisam avaliar estratégias alternativas para aumentar a produtividade, os teores de proteína e de óleo. O objetivo de sua pesquisa foi avaliar a seleção para aumentar o teor de proteínas em 50\% utilizando parcelas não repetidas para determinar a resposta correlacionada para produtividade, valor bruto por hectare, teor de óleo e a resposta direta para teor de proteína. Na média, a seleção para acréscimo de proteína resultou em um decréscimo da produtividade (Helms \& Orf, 1998).

Winkler et al. (2000) realizaram um estudo para encontrar correlações entre covariáveis ambientais de diferentes características agronômicas, utilizadas para analisar o grau de similaridade em suas tendências espaciais. Produtividade, teor de proteína e tamanho dos grãos foram mais influenciados por variações espaciais do que por tempo de florescimento, tempo de maturação e teor de óleo. Nos experimentos de campo com um alto grau de heterogeneidade espacial, as correlações entre covariáveis ambientais da produtividade e teor de proteínas dos grãos foram altamente positivas. Isso indicaria que condições de campo que promovem a produtividade iriam também aumentar o teor de proteínas. Os padrões de variação observados afetaram consideravelmente o cálculo de coeficientes fenotípicos de correlação entre produtividade de grãos e teor de proteínas, sugerindo que a análise espacial deveria ser aplicada a todas as características de interesse, quando as condições de campo não são homogêneas.

No caso de gerenciamento estratégico da cultura, se existirem dados disponíveis sobre a variabilidade do teor de óleo e proteína para cada variedade em função da localização no talhão, será possível tomar decisões do que plantar e onde, em função das necessidades de proteínas e óleo. O modelo de semivariograma que melhor representou a variabilidade espacial do teor de Extrato Etéreo (óleo) é o esférico e para a Proteína Bruta, o melhor é o exponencial. As distâncias a partir das quais os teores independem da posição são de 95,8m para Extrato Etéreo (óleo) e 54,4m para Proteína Bruta. O teor de Extrato Etéreo (óleo) variou de um mínimo de 12,95\% a um máximo de 
19,95\% e para o teor de Proteína Bruta, variou de um mínimo de 32,84\% a um máximo de 41,78\% (Balastreire et al., 2002).

\subsection{Variabilidade espacial dos atributos do solo}

Peck \& Melsted (1973) amostraram, em uma grade sistemática de 25,2m x 25,2m, o solo de duas áreas de 16,2 hectares e encontraram valores de $\mathrm{pH}$ médio de 6,6 e 6,2 para as duas áreas. Porém, o pH para essas áreas variou de 5,5 a 8,0.

Para Bouma (1997), é necessário um menor número de observações para se caracterizar a variabilidade espacial dos atributos dos solos em áreas mais homogêneas. Portanto, o procedimento para o estudo da variabilidade de parâmetros do solo deve partir da identificação de áreas mais homogêneas.

Algumas das mais importantes propriedades que determinam a produção das culturas incluem disponibilidade de água, drenagem, profundidade do solo, disponibilidade de nutrientes, textura, teor de matéria orgânica e pH (Mulla \& Schepers, 1997).

O manejo pode afetar propriedades químicas, físicas, mineralógicas e biológicas com impacto principalmente nas camadas superficiais do solo. Práticas como aração e gradagem são responsáveis pela alteração e até eliminação da dependência espacial de certas propriedades físicas do solo, densidade aparente, porosidade e retenção de água (Corá, 1997).

A aplicação de fertilizantes, assumindo-se mesmas quantidades aplicadas em toda a área, causa variabilidade adicional nos teores dos nutrientes do solo, principalmente para fósforo e potássio (Bouma \& Finke, 1993).

Langdale \& Schrader (1982) dizem que a disponibilidade do nitrogênio está concentrada quase que totalmente na camada de 0 a $0,3 \mathrm{~m}$ na forma de matéria orgânica, o que acontece também com $50 \%$ do fósforo disponível.

Yanai et al. (2001) determinaram o pH, a capacidade de troca de cátions, o carbono total, o nitrogênio total, a relação $\mathrm{C} / \mathrm{N}$, o fósforo disponível, o $\mathrm{N}$ inorgânico, o N mineralizável, além do $\mathrm{Ca}, \mathrm{Mg}, \mathrm{K}$ e $\mathrm{Na}$ em 100 amostras de solo coletadas em uma 
área de $50 \mathrm{~m} \times 100 \mathrm{~m}$ cultivada com arroz. A análise geoestatística indicou moderada a alta dependência espacial para as propriedades do solo exceto para o conteúdo de nitrogênio inorgânico. Uma dependência espacial com alcance de 20-30m foi encontrada para $\mathrm{pH}$, capacidade de troca de cátions, carbono total, nitrogênio total e $\mathrm{Na}$. Uma dependência espacial com alcance de $40 \mathrm{~m}$ foi observada para fósforo disponível, $\mathrm{N}$ mineralizável, $\mathrm{Ca}$ e $\mathrm{Mg}$. Já a relação $\mathrm{C} / \mathrm{N}$ e conteúdo de $\mathrm{K}$ apresentaram dependência espacial com alcance de 50-60m. A análise multivariada em combinação com geoestatística possibilitou explicar $65 \%$ da variação não-aleatória ou da estrutura espacial como fatores determinantes para a obtenção da produção de arroz.

Conhecer a variabilidade espacial de propriedades do solo, que controlam a produtividade de culturas, é um fator indispensável na implantação da Agricultura de Precisão, informam Corá \& Marques Junior (1998).

\subsubsection{A estatística no estudo da variabilidade de solos}

A fase mais importante do trabalho científico é a do planejamento (Aquino \& Duarte, 1986). É nessa fase que se deve pensar nas inferências que serão feitas, consultar o estatístico em caso de dúvidas e se conscientizar a respeito do método experimental e da importância de se conduzir bem os trabalhos, para que se atinjam os objetivos pretendidos. A experiência tem mostrado que pouca atenção tem sido dada ao plano experimental. Mas o sucesso de um experimento depende de suas bases e a base de um experimento é o seu projeto.

A precisão com que uma amostra de solo representa a população amostrada depende da variabilidade do solo, do número de amostras obtidas e do método de amostragem (Cline, 1944).

Dunn (1997) mostra a importância da escolha certa do tamanho das células do grid para a amostragem. Cita Don Bullock ${ }^{1}$, que diz que um grid de 2,5 acres (1 hectare) utilizado em grandes propriedades não funciona bem em solos que variam muito,

\footnotetext{
${ }^{1}$ Don Bullock, professor assistente de biometria e agronomia da Universidade de Illinois, EUA.
} 
fazendo com que o mapa criado não tenha correlação estatística com os verdadeiros tipos de solo da área. O que é o mesmo que tirar 20 ou 30 amostras da área e utilizar a média dos dados encontrados. Existem áreas que 2,5 acres de grid podem ser mapeados, mas há casos em que serão necessários grids de 1 acre $(0,4$ hectare $)$ para grandes propriedades.

Fraisse (1997) cita que para pequenas áreas, como a utilizada no seu experimento (1 hectare), grids de 20 a 30 metros são geralmente muito bons.

\subsubsection{A amostragem do solo}

A análise dos solos que retrata a variabilidade espacial do solo depende essencialmente do método de amostragem empregado que, por sua vez, está ligado ao delineamento experimental escolhido e aos objetivos do experimento (Corá \& Marques Junior, 1998).

Para Reichardt et al. (1986), há duas formas principais de amostragem: a coleta de amostras inteiramente casualizadas, pertencente à estatística clássica, sem levar em conta a posição relativa de cada amostra, em que a variabilidade é descrita pela estimativa da variância e pelo coeficiente de variação; e a coleta de amostras de acordo com um plano espacial determinado, sendo a amostragem segundo transecções em dada direção ou segundo um "grid" em duas direções, mantendo uma regularidade na coleta de amostras por toda área. Os autores salientam que a distância constante entre as amostras não é estritamente necessária, desde que a posição relativa de cada amostra seja conhecida. Libardi et al. (1986) salientam que o conhecimento da posição das amostras possibilitam avaliar a dependência espacial entre os valores medidos.

As análises estatísticas tradicionais, baseadas na independência das observações, têm sido substituídas por análises espaciais, as quais consideram as correlações entre observações vizinhas (Hamlett et al., 1986). Essas análises são baseadas na teoria das variáveis regionalizadas, base da geoestatística e, como resultado, a variabilidade espacial é caracterizada por meio de autocorrelogramas, semivariogramas e métodos de interpolação, como krigagem, que definem o grau de 
dependência no espaço da grandeza medida e o alcance ou domínio de cada amostragem medida (Vieira et al., 1997).

Journel \& Huijbregts (1978) sugeriram pelo menos 30 a 50 pares de pontos como mínimo para calcular cada classe de distância ("lag") do variograma, e Trangmar et al. (1985) dizem que em estudo de solos, a krigagem fornece a melhor estimativa de parâmetro local onde estes não foram amostrados, utilizando os parâmetros do semivariograma.

\subsection{Agricultura de Precisão}

A Agricultura de Precisão constitui uma ferramenta de grande potencialidade na racionalização do uso de insumos e de energia, no aumento da produtividade e na otimização financeira. Balastreire (1998) define Agricultura de Precisão como sendo um conjunto de técnicas que permite o gerenciamento localizado de culturas. A preocupação mundial em relação à aplicação dessa tecnologia refere-se à grande disponibilidade de informações, requerendo técnicos com experiência em interpretação dos dados coletados, na forma de mapas (Mantovani et al., 1998).

Antes da Revolução Industrial e do processo de mecanização da agricultura, os agricultores já eram capazes de reconhecer a variabilidade espacial de certas características físico-químicas e biológicas das áreas cultivadas (Fraisse, 1997). Até então, o uso do trabalho braçal e/ou da tração animal permitia aos agricultores tratar de áreas com menor ou maior fertilidade ou infestação por pragas e doenças de forma diferenciada. Com o advento da mecanização e da produção em larga escala, os campos cultivados passaram a ser tratados de maneira uniforme.

Essa maneira de tratar as áreas geralmente resulta numa aplicação uniforme de fertilizantes, herbicidas e tratamentos para controle de pragas (CAAP, 1997). Tal uniformidade de tratamentos ignora as variações naturais e induzidas nas propriedades do solo, e pode resultar em zonas com excesso e outras com falta de tratamentos, fazendo com que cresçam os problemas econômicos e ambientais associados a essa ineficaz aplicação de insumos no solo. 
As fases da Agricultura de Precisão podem ser subdivididas em: mapeamento dos atributos do solo e das plantas, mapeamento da produtividade das culturas e aplicação localizada de insumos (Balastreire, 1998). Todo esse processo é gerenciado pelo chamado Sistema de Informações Geográficas - SIG. O autor relata que o mapeamento da produtividade pode ser considerado a etapa de menor dificuldade de execução, em função do elevado número de pesquisas e equipamentos disponíveis para tal finalidade.

Segundo Balastreire (1994), na aplicação localizada, as quantidades de cada insumo são determinadas em função da análise dos mapeamentos dos atributos do solo e das plantas, do conhecimento agronômico e do histórico da área a ser cultivada. Segundo o autor, a aplicação localizada visa à alocação dos insumos em função dos requisitos específicos do local.

\subsubsection{Sistema de Posicionamento Global - GPS}

O Sistema de Posicionamento Global - GPS - foi desenvolvido pelo Departamento de Defesa dos Estados Unidos, e se originou em 1973 da fusão de dois projetos da Marinha e da Força Aérea, e recebeu a designação de "Navigation Satellite with Time and Ranging (NAVSTAR)", ou "Global Positioning System - GPS", e se tornou mais conhecido pela sigla NAVSTAR/GPS (Blitzkow, 1995).

De acordo com Lechner \& Bauman (2000), o GPS (Global Positioning System) foi posto em utilização no início da década de 80, porém somente em 1995 foi declarado totalmente operacional, ou seja, capaz de determinar posições em qualquer lugar do planeta, 24 horas por dia. Foi, inicialmente, designado para fins militares; entretanto, atualmente, o GPS vem sendo utilizado também na indústria, comércio e agricultura. De acordo com os autores, o GPS é composto por três segmentos: espacial, controle e usuário. O segmento espacial é constituído de 24 satélites distribuídos em seis órbitas a uma altitude de $20.000 \mathrm{~km}$. O segmento de controle é formado por diversas estações de rastreamento espalhadas pelo mundo, cuja função é determinar a órbita exata de cada um dos satélites e atualizar seus sinais de navegação. O segmento do usuário é 
formado pelo receptor GPS, que converte os sinais vindos dos satélites em informação de posicionamento, velocidade e estimativa de tempo.

De acordo com Ackroyd \& Lorimer (1994), os receptores de GPS calculam a sua posição através de uma técnica que envolve a medição da distância entre a antena do receptor e os satélites rastreados. Ao receberem os sinais dos satélites, os receptores calculam o tempo gasto por cada um dos sinais no percurso entre o satélite e a antena. Para calcular esse tempo, os receptores precisam saber o momento em que o sinal deixa o satélite e o momento em que o sinal alcança a antena. O momento em que o sinal alcança a antena é definido pelo receptor, que possui um relógio interno. Já o momento em que o sinal deixa o satélite é encontrado da seguinte forma: todos os receptores de GPS são sincronizados com os satélites e, portanto, geram o mesmo código digital simultaneamente. Quando o receptor recebe um código do satélite, ele o compara em seu banco de memória e verifica o momento em que o código foi emitido. Dessa forma, pode-se saber o momento exato em que o sinal deixou o satélite. A distância entre a antena do receptor e os satélites é determinada multiplicando-se o tempo encontrado pela velocidade dos sinais (velocidade da luz $-300.000 \mathrm{~km} / \mathrm{s}$ ). Segundo os autores, para calcular o posicionamento em termos tridimensionais (latitude, longitude e altitude) são necessárias as distâncias entre a antena do receptor a pelo menos quatro satélites.

Greer (1993), ao comentar a importância da localização precisa dos recursos naturais, mostra a conveniência da integração entre GPS, GIS e Sensoriamento Remoto. Descreve a importância do GPS no fornecimento ininterrupto de informações, a um custo menor do que com os levantamentos convencionais.

Lange (1996) alerta para a necessidade de todos os mapas de campo estarem georreferenciados no mesmo sistema (“datum”), pois pode haver uma diferença considerável entre um "datum" e outro, o que poderia causar erros posteriores. O GPS utiliza o datum "World Geodesic System - 1984 (WGS 84)". 


\subsubsection{Erros do GPS}

O GPS apresenta grandes perspectivas de crescimento no mundo e no Brasil. Em nível mundial, a utilização cada vez maior dessa tecnologia, suprindo as mais diversas áreas (mapeamento, geodésia, Agricultura de Precisão, coleta de dados para sistemas de informações geográficas, construção civil, controle de frota), gera uma demanda muito grande aos fabricantes, os quais, por sua vez, exercem cada vez mais pressão no Departamento de Defesa dos Estados Unidos - o responsável pelo programa - para criar mecanismos que possibilitem aumentar as vantagens para os usuários civis. As pressões já fizeram efeito na medida em que o governo americano extinguiu a "Disponibilidade Seletiva" (Selective Availability - SA), diminuindo o erro até 10 vezes, sendo essa a maior fonte de erro capaz de reduzir a acurácia dos cálculos de posicionamento dos receptores de GPS. Essa medida foi adotada em função dos avanços tecnológicos de degradação do sinal. Foi apresentado como um comunicado pela Casa Branca em 1ํำ de maio de 2000 (Lane et al., 2000). Em vez de a degradação ser ativada para o mundo, a tecnologia permite a degradação para regiões específicas, quando for de interesse do governo americano.

Lamparelli et al. (2001) comentam que o erro na exatidão das coordenadas se deve a vários fatores, dentre eles pode-se citar o erro no tempo do relógio do satélite, a atmosfera, o multicaminhamento e o erro do receptor. A Tabela 1 mostra alguns desses erros e como podem ser corrigidos. A maioria deles pode ser corrigida pela correção diferencial (DGPS).

\subsubsection{A correção diferencial do GPS (DGPS)}

Segundo Lamparelli et al. (2001), a correção diferencial é um método matemático capaz de melhorar a acurácia das medidas. A correção diferencial é utilizada comparando-se os resultados de dois aparelhos GPS, coletando dados ao mesmo tempo, e a distância não muito grande um do outro. O método consiste em colocar um dos aparelhos GPS em um ponto fixo com coordenadas bem conhecidas, que calcula e 
determina um fator de correção (vetor). O fator de correção resultante é armazenado para uso posterior, quando a correção é pós-processada. O vetor correção é comparado com os dados obtidos do receptor móvel, corrigindo-os. Opcionalmente, essas correções podem ser enviadas via rádio para o receptor móvel e, dessa maneira, corrigindo-os em tempo real. Esse procedimento chamado de correção diferencial pode diminuir o erro para centímetros ou até milímetros.

Tabela 1. Erros típicos devido a fatores diversos (adaptado de Hurn, 1989)

\begin{tabular}{lcc}
\hline Fontes - Erros Típicos & GPS (m) & DGPS (m) \\
\hline Relógio do Satélite & 1,5 & 0,0 \\
Órbita & 2,5 & 0,0 \\
Disponibilidade Seletiva (SA) & 30,0 & 0,0 \\
Ionosfera & 5,0 & 0,4 \\
Troposfera & 0,5 & 0,2 \\
Multicaminhamento & 0,6 & 0,6 \\
Ruído do Receptor & 0,3 & 0,3 \\
Típica Acurácia de Posicionamento (Horizontal) & $50,0(15,0 \mathrm{sem} \mathrm{SA})$ & 1,3 \\
Típica Acurácia de Posicionamento (Vertical) & $78,0(24,0 \mathrm{sem} \mathrm{SA})$ & 2,0 \\
\hline
\end{tabular}

*SA = Selective Availability (Disponibilidade Seletiva)

Segundo Fraisse (1998), é ideal que o mapa base de campo tenha a melhor acurácia possível, uma vez que vai servir de base para todas as análises e operações de campo. Quanto a dados coletados, como de solo e de produtividade da cultura, aceita-se uma acurácia na ordem de 1 a 3 metros. Já na aplicação de insumos localizados, há necessidade de maior acurácia, para não ocorrer sobreposicionamento, ou aplicações em locais incorretos. Comenta, também, que o uso da correção diferencial em tempo real é requerida na maioria das operações de campo, embora, em alguns casos, como na coleta de dados de produtividade com colhedoras, a correção possa ser pós-processada, concordando com Berry (1998).

De acordo com Algerbo \& Thylen (1997), a correção diferencial pode também ser obtida pelo uso de estações base. Os autores definem estação base (estação 
referência) como sendo um local de coordenadas conhecidas, onde é instalado um GPS e um rádio transmissor. Esse tipo de correção diferencial baseia-se no fato de que o erro de posicionamento que ocorre na estação base é simultaneamente idêntico aos erros que ocorrem em receptores de GPS a uma certa distância da base. Entretanto, por estar num ponto de coordenadas conhecidas, a estação base identifica o erro de posicionamento a cada segundo e envia, por meio de rádio transmissor, o sinal de correção aos receptores ao redor da base.

De acordo com Balastreire \& Baio (2002), uma outra forma de correção de posicionamento em tempo real são os algoritmos otimizados, já disponíveis no mercado. São programas instalados nos receptores de GPS que calculam a posição correta sem a necessidade de sinais de correção. Os autores concluíram ser viável sua utilização em Agricultura de Precisão, ao compararem esse equipamento a um GPS com correção diferencial por meio de sinais de satélite.

\subsubsection{Sistema de Informações Geográficas - SIG}

O desenvolvimento e uso de Sistema de Informações Geográficas - SIG - tem crescido visivelmente durante a última década, mas existem ainda muitas oportunidades para o desenvolvimento de pesquisas que contribuam para seu aperfeiçoamento. Openshaw (1988) aponta que a era de mapa digital em SIG está sendo ultrapassada pela demanda de análises geográficas mais específicas e avançadas e que, no futuro, será necessário incorporar procedimentos analíticos mais adequados e interligados com as facilidades existentes para a apresentação de dados geográficos.

Pelo conjunto de seus sistemas, o SIG pode ser considerado uma das principais ferramentas de análise de sistemas, como definidas por Grigg (1996), pois consiste num ambiente de armazenamento, tratamento e análise de dados, aplicação de modelos e processamento de séries temporais, onde é possível ver cenários passados, atuais e simular cenários futuros.

Num SIG, dados da variabilidade espacial de produtividade de uma cultura podem ser analisados conjuntamente com outros dados (ex. solos, modelos digitais de 
elevação, restrições) para se modelarem cenários futuros e avaliar a efetividade do manejo monitorado para cada área (Peccol et al., 1994). Além disso, as informações podem ser armazenadas e tratadas de maneira flexível e os resultados podem ser documentados num formato mais adequado para tomadores de decisão como o produtor, os consultores e os prestadores de serviço.

O SIG, como definido por Burrough (1986), é um "poderoso elenco de ferramentas para colecionar, armazenar, recuperar, transformar e exibir dados espaciais referenciados ao mundo real". Na verdade, existem diversas definições para o que é um SIG, porém Silva (1999) sintetizou-as na definição dos requisitos necessários a um sistema para que esse seja considerado um SIG: "O SIG necessita usar o meio digital, portanto o uso intensivo de informática é imprescindível; deve existir uma base de dados integrada, esses dados precisam estar geo-referenciados e com controle de erros; o SIG deve conter funções de análise desses dados, variando de álgebra cumulativa (ex: operações do tipo soma, subtração, multiplicação e divisão) até álgebra não-cumulativa (operações lógicas)".

O SIG normalmente integra diversos outros sistemas (ex: processamento digital de imagens, análise estatística, análise geográfica, digitalização para ser capaz de realizar estas operações e ainda dispor de entrada e saída de dados em diversos formatos, tendo como ponto central um banco de dados. A Figura 1 mostra os diversos sistemas que podem integrar um SIG. 


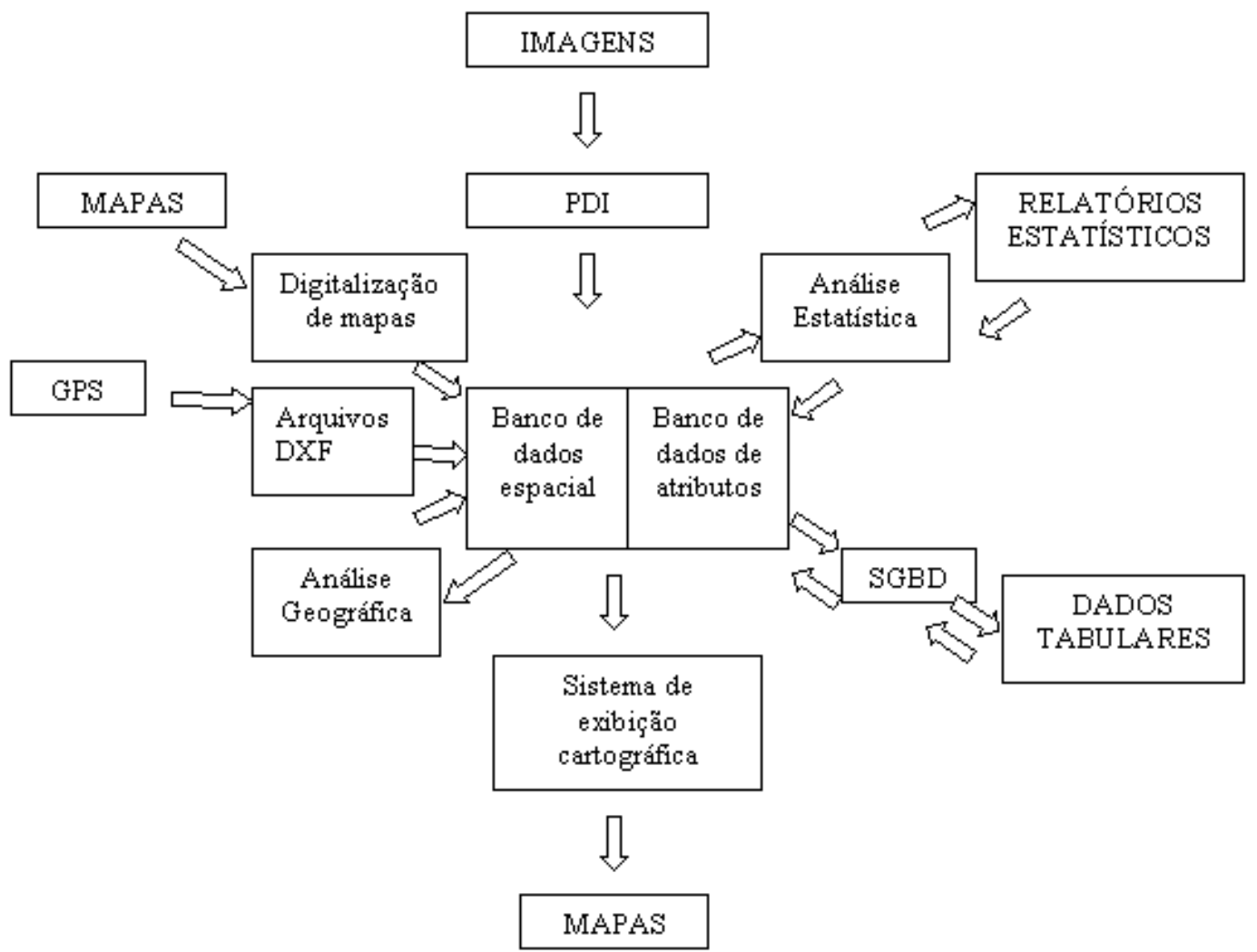

Figura 1 - Sistemas que integram um SIG (Adaptado de Eastman, 1993)

GPS $=$ Sistema de Posicionamento Global; DXF = Extensão para trabalhar com planilhas eletrônicas; PDI $=$ Sistemas de processamento digital de imagens e SGDB = Sistema de gerenciamento de banco de dados

Dessa forma, os sistemas que compõem o SIG podem ser divididos em:

- Sistemas de entrada de dados: sistemas de processamento digital de imagens (PDI), digitalização de mapas, sistema de posicionamento global (GPS), dados tabulares (planilhas eletrônicas) e dados estatísticos;

- Sistemas de armazenamento de dados: banco de dados espacial (mapas digitais) e banco de dados de atributos (alfanuméricos);

- Sistemas de análise de dados: sistema de análise geográfica (operações algébricas), sistema de análise estatística e sistema de gerenciamento de 
banco de dados (SGBD);

- Sistema de saída de dados: sistema de exibição cartográfica (saída de mapas para a tela, impressora, "plotter" e arquivos digitais).

\subsection{A estatística no estudo da variabilidade}

\subsubsection{A estatística clássica ou de Fisher}

Garcia (1997) resume estatística clássica como sendo aquela que utiliza a média e o desvio padrão para representar um conjunto de dados, e baseia-se na hipótese principal de que as variações de um local a outro são aleatórias.

Segundo Morettin \& Bussab (1987), as medidas estatísticas mais utilizadas para expressar a variabilidade de um conjunto de dados são a variância ou desvio padrão, o coeficiente de variação e a amplitude total, por serem fáceis de se calcular e de se interpretar. Porém, esses indicadores devem ser utilizados com certas restrições.

Guimarães (1993) mostra que a variância só poderá ser usada, isoladamente, se forem comparados grupos de dados que possuem unidades e médias iguais. $\mathrm{O}$ coeficiente de variação, que indica o grau de variabilidade do parâmetro, não reflete o seu significado físico, mas é bastante utilizado para comparar propriedades que possuam unidades diferentes. A amplitude total leva em consideração apenas os extremos, sendo, portanto, pouco utilizada.

Sokal \& Rohlf (1969) afirmam que os valores num ponto são estimados levando-se em conta a média da população e a variabilidade dos valores medidos em torno da média. Essa estimativa pressupõe que as amostras sejam independentes e que possuam distribuição normal.

Heath (1981) mostra que se a distribuição de freqüência for diferente da normal, deve-se realizar uma transformação de dados para a normalização e o uso da estatística clássica. A normalidade dos dados é um pré-requisito básico para o uso da estatística clássica.

Um teste de verificação de normalidade dos dados obtidos pelo "software" 
estatístico SAS é dado pela estatística W, o método de Shapiro-Wilk, apresentado em Shapiro \& Wilk (1965). Esse método tem como resultado o valor da estatística W, podendo variar de 0 a 1 , e o valor de probabilidade ("p-value"), que descreve quão duvidosa a idéia de normalidade é, também variando de 0 a 1 .Valores para $\mathrm{W}$ próximos a 1 e "p-values" altos caracterizam uma normalidade. A estatística W e o "p-value" desta devem ser analisados em conjunto.

Outro teste de verificação de normalidade dos dados é feito por meio dos coeficientes de assimetria e curtose (Guimarães, 1993). Assimetria é o grau de desvio ou afastamento da simetria de uma distribuição, que pode ser dada pelo $1^{\underline{0}}$ coeficiente de Pearson:

$$
\mathrm{C}_{\mathrm{s}}=\frac{\bar{X}-M_{0}}{s},
$$

sendo:

$C_{s}$ é o coeficiente de assimetria;

$\bar{X}$ é a estimativa da média populacional;

$M_{0}$ é a moda e

s é a estimativa do desvio padrão populacional.

A moda corresponde à classe de maior freqüência da distribuição (Costa Neto, 1977). Ela pode não existir ou ainda, quando existir, pode não ser única.

Segundo Guimarães (1993), os "softwares" em geral utilizam outra fórmula para o cálculo da assimetria, dada por:

$$
a_{3}=\frac{M_{3}}{s_{3}},
$$


sendo:

$a_{3}$ é o índice de assimetria;

$M_{3}$ é momento de $3^{\mathrm{a}}$ ordem, dado por: $\frac{\sum_{i=1}^{n}\left(X_{i}-\bar{X}\right)^{3}}{n} \mathrm{e}$

$s_{3}$ é a estimativa do desvio padrão populacional elevada ao cubo.

Segundo Guimarães (1993), a curtose mede o grau de achatamento de uma curva em relação à distribuição normal, e é dada por:

$$
C_{r}=\frac{M_{4}}{s_{4}}
$$

sendo:

$C_{r}$ é o coeficiente de curtose;

$M_{4}$ é o momento de $4^{\mathrm{a}}$ ordem, dado por: $\frac{\sum_{i=1}^{n}\left(X_{i}-\bar{X}\right)^{4}}{n} \mathrm{e}$

$s_{4}$ é o quadrado da variância.

O mesmo autor diz que os valores de $C_{s}=0$ e $C_{r}=3$ caracterizam uma normalidade dos dados. No SAS os coeficientes de assimetria e curtose próximos a 0 (zero) aproximam a distribuição da Normal Padrão. As estimativas da média e do desvio padrão são dadas por:

$$
\bar{X}=\frac{\sum X_{i}}{n} \quad \text { e } \quad S=\sqrt{\frac{\sum\left(X_{i}-\bar{X}\right)^{2}}{n-1}}
$$


Segundo Costa Neto (1977), a média constitui-se na média simples dos dados, e o desvio padrão constitui-se na raiz quadrada da variância, assim, o desvio padrão apresenta as mesmas unidades que a variável em análise.

A amplitude total dos dados é o intervalo total de variação dos dados (Costa Neto, 1977), que é igual a:

$$
\mathrm{A}=\mathrm{X}_{\text {máx }}(\text { valor máximo })-\mathrm{X}_{\text {mín }}(\text { valor mínimo })
$$

A variância de um conjunto de dados é, por definição, a média dos quadrados das diferenças dos valores em relação à sua média (Costa Neto, 1977), e é dada por:

$$
S^{2}=\frac{\sum\left(X_{i}-\bar{X}\right)^{2}}{n-1},
$$

Guimarães (1993) diz que o coeficiente de variação é dado por:

$$
C V=s / \bar{X}
$$

sendo:

$\bar{X}$ é a média amostral;

$X_{i}$ é a i-ésima observação amostral;

$s$ é o desvio padrão e

$n$ é o tamanho da amostra.

O coeficiente de variação constitui-se em uma medida de dispersão relativa e também numa alternativa para avaliar a simetria das distribuições (Sturaro, 1993). Valores de coeficientes de variação maiores que 1 significam a presença de valores altos e/ou erráticos no conjunto de dados, que representarão problemas para a maioria dos 
métodos de estimativas (Kim, 1988).

\subsubsection{A análise exploratória de dados}

A análise exploratória dos dados é fundamental e obrigatória dentro de qualquer estudo geoestatístico. É uma etapa precursora introduzida para averiguar as propriedades estatísticas e matemáticas dos dados (Burrough et al., 1996).

Uma etapa fundamental que antecede a análise geoestatística é a realização de uma criteriosa análise exploratória dos dados. Deve-se verificar a normalidade dos dados, verificar se há candidatos a dados discrepantes (“outliers") ou se há a necessidade da transformação dos dados para a sua normalização (Isaaks \& Srivastava, 1989 e Gonçalves et al.,1999).

Garcia (1997) cita duas técnicas utilizadas na análise exploratória de dados: o dispositivo de ramo e folhas e o gráfico de "boxplot". O dispositivo ramo e folhas possibilita ver quanto o grupo está próximo da simetria, como estão distribuídos os valores, se estão distanciados demais e se existe concentração dos dados ou lacunas. Ele é similar a um histograma na apresentação dos dados, e os dados discrepantes (“outliers") são imediatamente localizados. Os discrepantes (“outliers”) são aqueles que estão afastados demais do conjunto de dados, são os pontos extremos. O "boxplot" é um gráfico construído desenhando-se uma caixa com extremidades nos quartos inferior e superior e com uma barra na mediana. Em seguida, traça-se uma linha até os pontos mais afastados, que são os dados discrepantes (“outliers"), os quais são representados individualmente por pontos situados além dos limites críticos para dados periféricos. Cada "boxplot" dá a mediana, a dispersão dos dados, a assimetria, a distribuição e os dados discrepantes (“outliers”).

$\mathrm{Na}$ distribuição dos quartos ou quartis, usada para a criação do "boxplot", temse o valor do $1^{\underline{o}}$ quartil, que corresponde ao ponto onde estão até $25 \%$ dos dados, o $2^{\underline{o}}$ quartil ou mediana, com $50 \%$ dos dados e o $3^{\circ}$ quartil, com $75 \%$ dos valores (Garcia, 1997). A amplitude quartílica dos dados é definida como sendo o valor do $3^{\text {o }}$ quartil menos o valor do $1^{\underline{0}}$ quartil, e os valores que estão abaixo do $1^{\underline{0}}$ quartil menos $3 / 2$ da 
amplitude quartílica ou acima do $3^{-}$quartil mais $3 / 2$ da amplitude serão os dados discrepantes ("outliers").

O valor $3 / 2$ é meio arbitrário, mas se tem mostrado utilizável para a identificação dos "outliers" (Emerson \& Strenio, 1983).

A estatística clássica não permite testar a independência entre as amostras; portanto, ao se aplica-la, está se assumindo independência entre amostras sem testar (Guimarães, 1993). Embora existam alguns testes não-paramétricos de independência amostral, estes quase não são utilizados.

Para o autor, a quantificação de características e propriedades do solo são influenciadas pela variabilidade espacial. Assim, existe uma certa dependência entre amostras, e uma média simples não é representativa da área de estudo. Nesse caso, é mais indicado o uso de estimativas que levem em consideração a posição espacial dos valores amostrados.

Mas o que também deve ser considerado é a existência, muitas vezes, de uma estrutura de dependência ou correlação entre os parâmetros envolvidos no sistema. A correlação entre dois parâmetros pode ser estimada pela correlação de Pearson (Seber, 1977), conceito básico de Estatística a qual pode ser utilizada como análise exploratória de um conjunto de dados antes do ajuste de um modelo de regressão simples (com uma variável independente e outra dependente) assim como os modelos de regressão múltipla (com uma variável dependente e várias independentes) são bastante populares na Agricultura de Precisão.

\subsubsection{Geoestatística ou a teoria das variáveis regionalizadas}

Segundo Landim (1998), a geoestatística é um tópico especial da estatística aplicada que trata de problemas referentes às variáveis regionalizadas, as quais têm um comportamento espacial que mostram características intermediárias entre as variáveis verdadeiramente casuais e as totalmente determinísticas. Apresentam uma aparente continuidade no espaço, sendo representada por funções numéricas ordinárias que assumem um valor definido a cada ponto no espaço e descrevem matematicamente um 
fenômeno natural. A continuidade geográfica é representada pela tendência que a variável tem, ou seja, valores são parecidos a dois pontos vizinhos e mais diferentes à medida que os pontos vão ficando mais distantes. Esse tipo de variável apresenta outros atributos como: localização, anisotropia e transição.

De acordo com Mulla (1997), após a coleta das amostras do solo e sua análise para determinar propriedades, seus resultados são interpolados para as localidades que não foram amostradas por técnicas de geoestatística, e os valores interpolados são classificados usando um sistema de informações geográficas para um número limitado de zonas de gerenciamento. Os contornos dessas zonas são, então, percebidos por meio de um "software" de mapeamento, e as recomendações são firmadas para cada zona. As recomendações de gerenciamento e os limites das zonas são armazenados num "chip" de computador colocado num trator, plantadora ou adubadora capaz de mudar as aplicações de acordo com a localização no campo e nos limites das zonas.

Segundo Matheron (1963), a geoestatística é uma função que varia de um lugar a outro no espaço com certa aparência de continuidade. São variáveis cujos valores estão relacionados com a posição espacial que ocupam, e já que podem tomar valores diferentes em diferentes lugares de observações, demonstram uma certa independência de um lugar a outro.

Fanha (1994) diz que as variáveis regionalizadas têm características quantitativas, tais como: localização, continuidade e anisotropia que estão ligadas ao fenômeno natural que elas representam. A variável regionalizada atua num espaço geométrico em que foi definida e onde será estudada sua variação.

Quando se utiliza a ferramenta geoestatística para a análise dos dados, algumas hipóteses de trabalho são assumidas, principalmente a hipótese intrínseca. Por ela, a probabilidade de variação dos valores tomados entre pontos com a mesma distância de separação é igual, ou seja, a relação da dependência espacial é a mesma em qualquer posição de $\mathrm{h}$ (h é o vetor que separa dois pontos amostrais). É assumida a estacionaridade dentro do alcance da continuidade espacial. A estacionaridade de primeira ordem é a esperança do valor de um ponto no espaço ser igual à média, admitindo-se que a média amostral é igual à média populacional. A estacionaridade de 
segunda ordem assume que há uma variação da média, mas a variância é constante dentro dos limites da continuidade espacial (Isaaks \& Srivastava, 1989 e Vieira, 1995).

A geoestatística aplicada à Agricultura de Precisão tem por objetivos identificar, na aparente desordem entre as amostras, uma medida da correlação espacial, realizar estimativas de valores de locais não amostrados com base em alguns valores conhecidos na população (krigagem) e identificar inter-relações de propriedade no espaço (análises de correlação entre atributos), além de permitir estudar padrões de amostras adequadas (Vieira, 2000).

\subsubsection{O variograma}

O variograma é uma ferramenta básica de suporte às técnicas de krigagem, que permite representar quantitativamente a variação de um fenômeno regionalizado no espaço (Huijbregts, 1975).

Camargo (1997) considera duas variáveis, $X$ e $Y$, onde $X=Z(x)$ e $Y=Z(x+h)$, neste caso, referindo-se ao mesmo atributo (por exemplo, o teor de zinco no solo) medido em duas posições diferentes, conforme ilustra a Figura 2, onde x denota uma posição em duas dimensões, com componentes $\left(\mathrm{x}_{\mathrm{i}}, \mathrm{y}_{\mathrm{i}}\right)$, e $\mathrm{h}$ um vetor distância (módulo e direção) que separa os pontos.

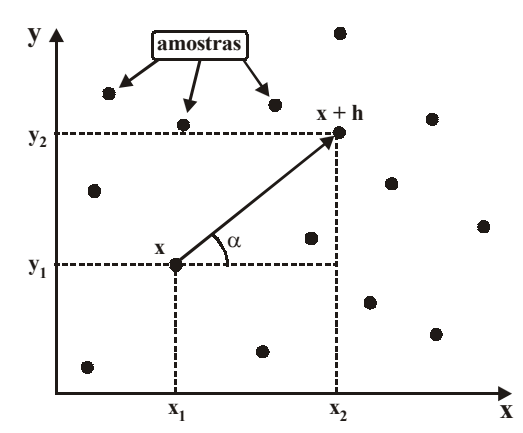

Figura 2 - Amostragem em duas dimensões (Camargo, 1997)

Camargo (1997) diz que o nível de dependência entre essas duas variáveis 
regionalizadas, $\mathrm{X}$ e $\mathrm{Y}$, é representado pelo variograma, $2 \gamma(\mathrm{h})$, o qual é definido como a esperança matemática do quadrado da diferença entre os valores de pontos no espaço, separados pelo vetor distância h, isto é,

$$
2 \gamma(h)=E\left\{[Z(x)-Z(x+h)]^{2}\right\}=\operatorname{Var}[Z(x)-Z(x+h)]
$$

De acordo com esse autor, através de uma amostra $\mathrm{z}\left(\mathrm{x}_{\mathrm{i}}\right), \mathrm{i}=1,2, \ldots, \mathrm{n}, \mathrm{o}$ variograma pode ser estimado por

$$
2 \hat{\gamma}(h)=\frac{1}{N(h)} \sum_{i=1}^{N(h)}\left[z\left(x_{i}\right)-z\left(x_{i}+h\right)\right]^{2}
$$

sendo:

$2 \hat{\gamma}(h)$ é o variograma estimado;

$\mathrm{N}(\mathrm{h})$ é o número de partes de valores medidos, $\mathrm{z}(\mathrm{xi})$ e $\mathrm{z}(\mathrm{xi}+\mathrm{h})$, separados por um vetor distância $\mathrm{h}$ e

$z(x i)$ e $z(x i+h)$ são valores da i-ésima observação da variável regionalizada, coletados nos pontos $x_{i}$ e $x_{i}+h(i=1, \ldots, n)$, separados pelo vetor $h$.

O mesmo autor define variograma de forma distinta da Equação (11), considerando o que comumente se refere como semivariograma, dado por:

$$
\gamma(h)=\frac{1}{2} E\left\{[Z\{x\}-Z(x+h)]^{2}\right\}=\frac{1}{2} \operatorname{Var}[Z(x)-Z(x+h)]
$$

Analogamente, a função semivariograma pode ser estimada por Vieira, (1995):

$$
\hat{\gamma}(h)=\frac{1}{2 N(h)} \sum_{i=1}^{N(h)}\left[z\left(x_{i}\right)-z\left(x_{i}+h\right)\right]^{2}
$$


sendo:

$\hat{\gamma}(h)$ é a semivariância;

$\mathrm{z}\left(\mathrm{x}_{\mathrm{i}}\right)$ e $\mathrm{z}\left(\mathrm{x}_{\mathrm{i}}+\mathrm{h}\right)$ são os pares de valores medidos separados por um vetor $\mathrm{h}$;

$\mathrm{N}(\mathrm{h})$ é o número de pares de valores $\left[\mathrm{z}\left(\mathrm{x}_{\mathrm{i}}\right)-\mathrm{z}\left(\mathrm{x}_{\mathrm{i}}+\mathrm{h}\right)\right]$ separados pelo vetor $\mathrm{h}$ e

z é a variável em estudo.

Fanha (1994) define o variograma como a medida do grau de dissimilaridade das amostras na proporção em que a distância entre as observações aumenta. $\mathrm{O}$ variograma é, portanto, uma função que expressa a variabilidade de uma dada propriedade entre dois pontos separados por uma distância "h", em função desta distância "h".

\subsubsection{Parâmetros do semivariograma}

Segundo Camargo (1997), a Figura 3 ilustra um semivariograma experimental com características muito próximas do ideal. O seu padrão representa o que, intuitivamente, se espera de dados de campo, isto é, que as diferenças $\left\{\mathrm{Z}\left(\mathrm{x}_{\mathrm{i}}\right)-\mathrm{Z}\left(\mathrm{x}_{\mathrm{i}+\mathrm{h}}\right)\right\}$

decresçam à medida que $h$, a distância que os separa, decresce. É esperado que observações mais próximas geograficamente tenham um comportamento mais semelhante entre si do que aquelas separadas por maiores distâncias. Dessa maneira, é esperado que $\gamma(\mathrm{h})$ aumente com a distância $h$. 


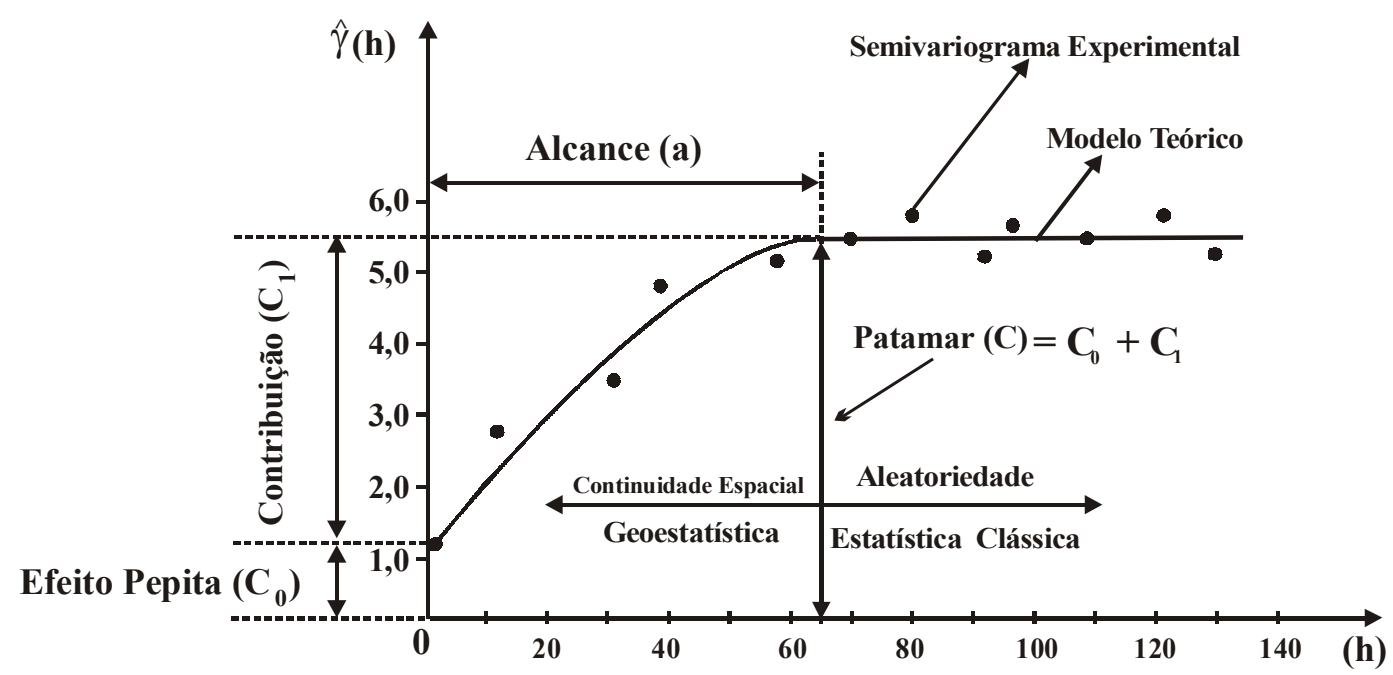

Figura 3 - Semivariograma experimental, modelo teórico e o semivariograma típico e seus componentes (Adaptado de Camargo, 1997)

Segundo esse autor, o semivariograma experimental é ajustado à curva que proporcione a máxima correlação possível com os pontos plotados. O modelo ajustado é chamado de modelo teórico do semivariograma. Na região onde se observa a continuidade espacial, a geoestatística é aplicada com eficiência (Figura 3).

Os parâmetros do semivariograma podem ser observados diretamente da Figura 3:

- Alcance (a): distância dentro da qual as amostras apresentam-se correlacionadas espacialmente. Na Figura 3, o alcance ocorre próximo de $65 \mathrm{~m}$.

- Patamar (C): é o valor do semivariograma correspondente a seu alcance (a). Desse ponto em diante, considera-se que não existe mais dependência espacial entre as amostras, porque a variância da diferença entre pares de amostras $(\operatorname{Var}[\mathrm{Z}(\mathrm{x})-\mathrm{Z}(\mathrm{x}+\mathrm{h})]$ torna-se invariante com a distância.

- Efeito Pepita $\left(\mathrm{C}_{0}\right)$ : por definição, $\gamma(0)=0$, (refira-se a equação 13$)$. Entretanto na prática, à medida que $\mathrm{h}$ tende para 0 (zero), $\gamma(\mathrm{h})$ se aproxima de um valor positivo chamado Efeito Pepita $\left(\mathrm{C}_{0}\right)$. O valor de $\mathrm{C}_{0}$ revela a descontinuidade do semivariograma para distância menores do que a menor 
distância entre as amostras. Parte dessa descontinuidade pode ser também devida a erros de medição (Isaaks \& Srivastava, 1989), mas é impossível quantificar se a maior contribuição provém dos erros de medição ou da variabilidade de pequena escala não captada pela amostragem.

- Contribuição $\left(\mathrm{C}_{1}\right)$ : é a diferença entre o Patamar $(\mathrm{C})$ e o Efeito Pepita $\left(\mathrm{C}_{0}\right)$.

\subsubsection{Modelos teóricos de semivariograma}

Camargo (1997) diz que o gráfico do semivariograma experimental, $\hat{\gamma}(\mathrm{h})$, calculado pela equação (14), é formado por uma série de valores, conforme ilustra a Figura 3, sobre os quais se objetiva ajustar uma função. É importante que o modelo ajustado apresente a tendência de $\hat{\gamma}(\mathrm{h})$ em relação a $\mathrm{h}$. Desse modo, as estimativas obtidas com a krigagem serão mais exatas e, portanto, mais confiáveis.

De acordo com esse autor, o procedimento de ajuste não é direto e automático, como no caso de uma regressão, por exemplo, mas sim interativo, pois nesse processo o intérprete faz um primeiro ajuste e verifica a adequação do modelo teórico. Dependendo do ajuste obtido, pode ou não redefinir o modelo, até obter um que seja considerado satisfatório. A seguir, são apresentados os principais modelos teóricos de semivariograma. Os modelos mais utilizados são o esférico, o exponencial e o gaussiano (Vieira, 2000).

\section{- Modelo efeito pepita}

Conforme discutido na Seção 2.4.4.1, muitos semivariogramas experimentais apresentam uma descontinuidade na origem (Camargo, 1997), quando $|\mathrm{h}|=0$, o valor do semivariograma é estritamente zero. Porém, quando $|\mathrm{h}|$ tende a zero, o valor do semivariograma pode ser significativamente maior que zero, isto é, ocorre uma descontinuidade na origem. Esse modelo é representativo de fenômenos naturais de elevada aleatoriedade e sua expressão matemática é assim definida: 
$\gamma_{\mathrm{o}}(|\mathrm{h}|)=\left\{\begin{array}{c}0 \text { se }|\mathrm{h}|=0 \\ 1 \text { se }|\mathrm{h}| \neq 0\end{array}\right.$

$\mathrm{Na}$ literatura geoestatística, o efeito pepita não é classificado como modelo básico, mas aparece como uma constante $\left(C_{0}\right)$ na equação do semivariograma, e deve ser entendido que $C_{o}=0$ quando $|h|=0$. A rigor, a notação para o efeito pepita é $C_{o} \gamma_{o}(|h|)$, onde $\mathrm{C}_{\mathrm{o}}$ representa o valor da descontinuidade na origem, e $\gamma_{\mathrm{o}}(|\mathrm{h}|)$ é o modelo de efeito pepita normalizado conforme apresentado na Equação (15). Essa notação é consistente com a apresentação dos modelos básicos aqui descritos e torna-se conveniente quando se usa modelo composto. O modelo efeito pepita está representado na Figura 4, abaixo:

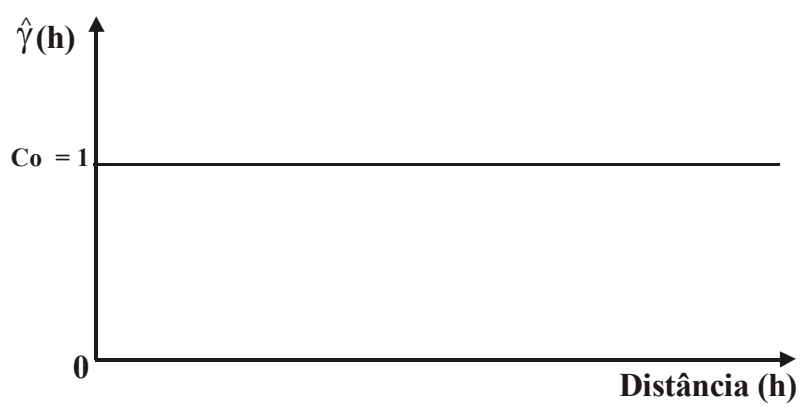

Figura 4 - Representação gráfica do modelo efeito pepita (Modificado de Sturaro, 1993)

\section{- Modelo esférico}

De acordo com Camargo (1997), o modelo esférico é um dos mais utilizados e está representado na Figura 5. A equação normalizada deste modelo é:

$$
\gamma(\mathrm{h})= \begin{cases}0 & ,|\mathrm{~h}|=0 \\ C_{0}+C_{1}\left[1,5\left(\frac{|h|}{\mathrm{a}}\right)-0,5\left(\frac{|h|}{\mathrm{a}}\right)^{3}\right]=C_{0}+C_{1}[\operatorname{Sph}(|h|)] & , 0<|\mathrm{h}| \leq \mathrm{a} \\ 1 & ,|\mathrm{~h}|>\mathrm{a}\end{cases}
$$




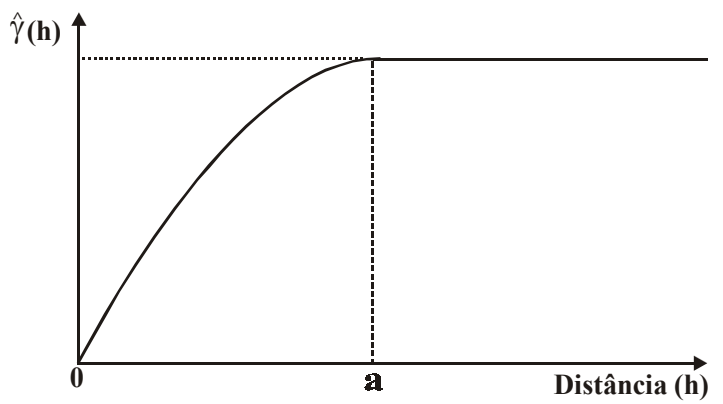

Figura 5 - Representação gráfica do modelo esférico (Modificado de Isaaks \& Srivastava, 1989)

\section{- Modelo exponencial}

Um outro modelo bastante utilizado é o modelo exponencial. A equação normalizada desse modelo é:

$$
\gamma(\mathrm{h})= \begin{cases}0 & ,|\mathrm{~h}|=0 \\ C_{0}+C_{1}\left[1-e^{\left(-\frac{|h|}{\mathrm{a}}\right)}\right]=C_{0}+C_{1}[\operatorname{Exp}(|h|)] & ,|\mathrm{h}| \neq 0\end{cases}
$$

Esse modelo atinge o patamar assintoticamente, com o alcance prático definido como a distância na qual o valor do modelo é $95 \%$ do patamar (Isaaks \& Srivastava, 1989). 


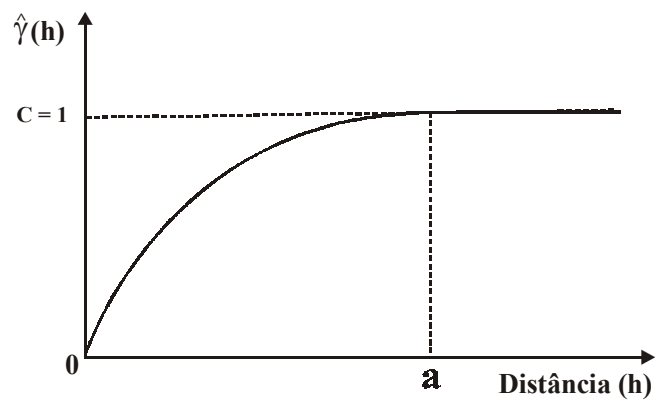

Figura 6 - Representação gráfica do modelo exponencial (Modificada de Isaaks \& Srivastava, 1989)

\section{- Modelo gaussiano}

O modelo gaussiano é um modelo transitivo, muitas vezes usado para modelar fenômenos extremamente contínuos (Isaaks e Srivastava, 1989). Sua formulação é dada por:

$$
\gamma(\mathrm{h})= \begin{cases}0 & ,|\mathrm{~h}|=0 \\ C_{0}+C_{1}\left[1-e^{\left(-\frac{|h|}{\mathrm{a}}\right)^{2}}\right]=C_{0}+C_{1}[\operatorname{Gau}(|h|)] & ,|\mathrm{h}| \neq 0\end{cases}
$$

Semelhante ao modelo exponencial, o gaussiano atinge o patamar assintoticamente e o parâmetro $a$ é definido como o alcance prático ou distância na qual o valor do modelo é 95\% do patamar (Isaaks \& Srivastava, 1989). O que o caracteriza é seu comportamento parabólico próximo à origem, conforme representado na Figura 7. 


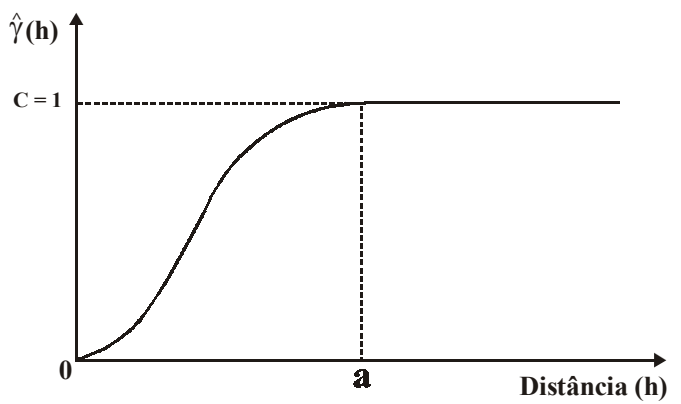

Figura 7 - Representação gráfica do modelo gaussiano (Modificada de Isaaks \& Srivastava, 1989)

\section{- Modelo linear}

O modelo linear descreve um variograma de linha reta. Observe que não há nenhuma soleira nele. O alcance (a) está arbitrariamente definido para ser o intervalo de distância do último ponto do semivariograma. Sua fórmula é dada por:

$$
\gamma(\mathrm{h})= \begin{cases}C_{0}+\left[|h|\left(\frac{C_{1}}{\mathrm{a}}\right)\right]=C_{0}+C_{1}[\operatorname{Lin}(|h|)] & ,|\mathrm{h}|>0\end{cases}
$$

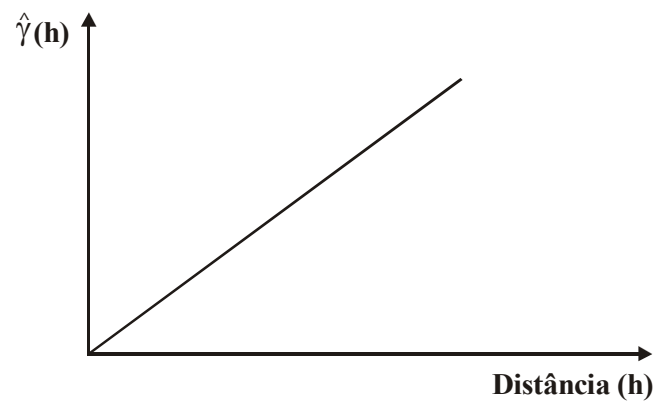

Figura 8 - Representação do modelo linear (Modificado de Golden Software, 1995) 


\subsubsection{Semivariogramas isotrópicos e anisotrópicos}

A anisotropia pode ser facilmente constatada através da observação dos semivariogramas obtidos para diferentes direções (Camargo, 1997). As convenções direcionais usadas na geoestatística são mostradas na Figura 9.

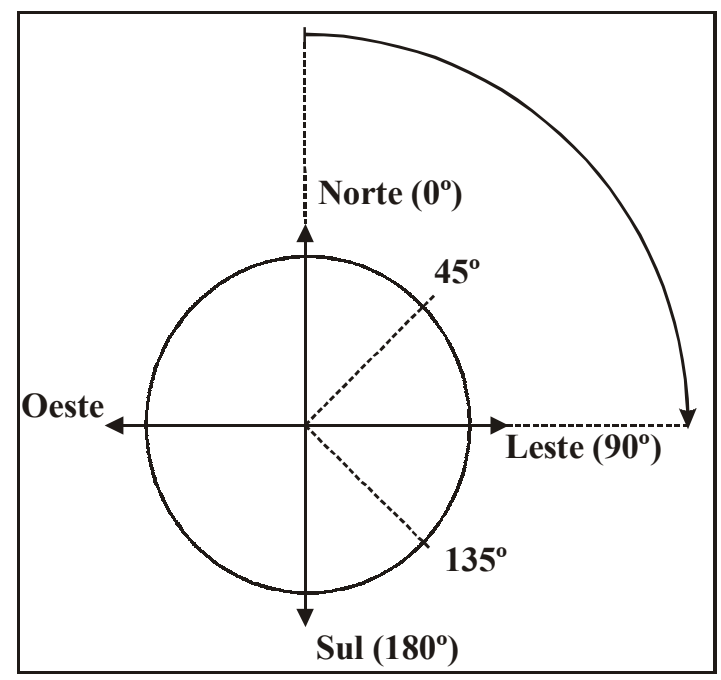

Figura 9 - Convenções direcionais usadas na geoestatística (Camargo, 1997)

O mesmo autor considera os semivariogramas obtidos para as direções $0^{\circ}, 45^{\circ}$, $90^{\circ}$ e $135^{\circ}$, ilustrados na Figura 10 e verifica uma similaridade bastante grande entre eles. Essa é a representação de um caso simples e menos freqüente, em que a distribuição espacial do fenômeno é denominada isotrópica. Nesse caso, um único modelo é suficiente para descrever a variabilidade espacial do fenômeno em estudo. 


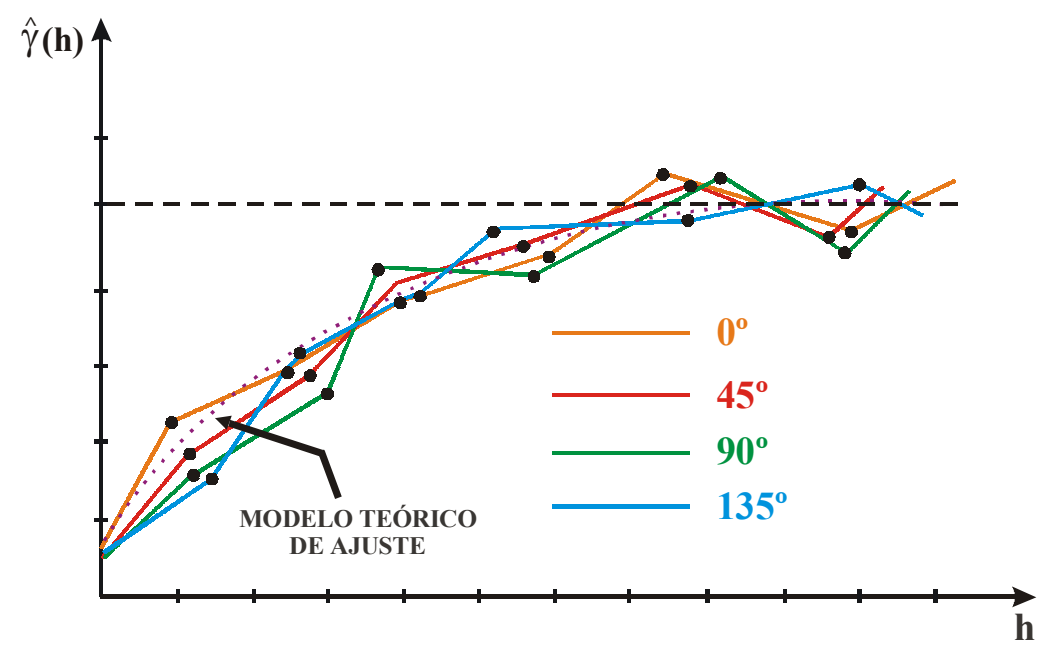

Figura 10 - Representação gráfica de semivariogramas isotrópicos (Camargo, 1997)

Por outro lado, Camargo (1997) diz que se os semivariogramas não são iguais em todas as direções, a distribuição é denominada anisotrópica. Se a anisotropia é observada e é refletida pelo mesmo Patamar (C) com diferentes Alcances (a) do mesmo modelo, então ela é denominada Geométrica.

Considerando o semivariograma ilustrado na Figura 11, os pontos interligados com linhas tracejadas são os semivariogramas experimentais em duas direções ortogonais (Camargo, 1997). O semivariograma que atinge primeiro o patamar (azul) se refere à direção de $120^{\circ}$ e o semivariograma com maior alcance (vermelho) se refere à direção de $30^{\circ}$. As linhas sólidas em ambas as direções são os modelos teóricos de ajuste dos semivariogramas experimentais. 


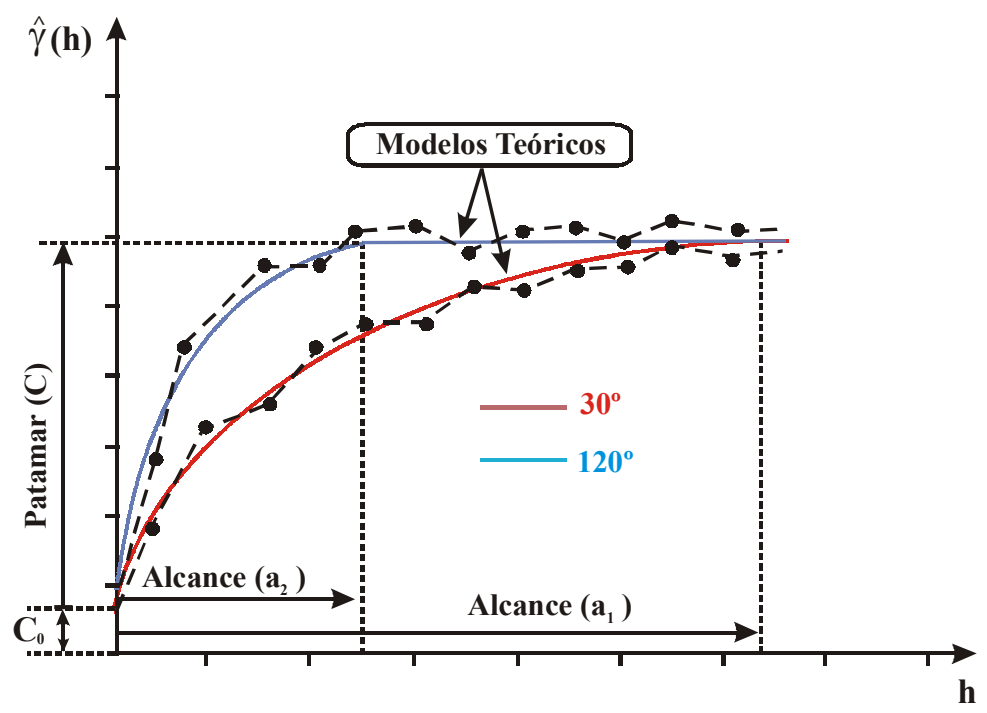

Figura 11 - Representação gráfica de anisotropia geométrica (Camargo, 1997)

Um modo direto de visualizar e calcular os parâmetros (fator e ângulo) da anisotropia geométrica é por meio do esboço gráfico de uma elipse, calculada pelos alcances obtidos em direções distintas, conforme a Figura 12. As convenções que seguem são as adotadas por Deutsch \& Journel (1992). Para o eixo maior da elipse, denominado direção de máxima continuidade, aplica-se ao maior alcance $\left(\mathrm{a}_{1}\right)$. O ângulo da direção de máxima continuidade é definido a partir da direção Norte e no sentido horário. Seu valor corresponde à direção de maior alcance. O eixo menor define o alcance $\left(\mathrm{a}_{2}\right)$ na direção de menor continuidade, sendo ortogonal à direção principal. 


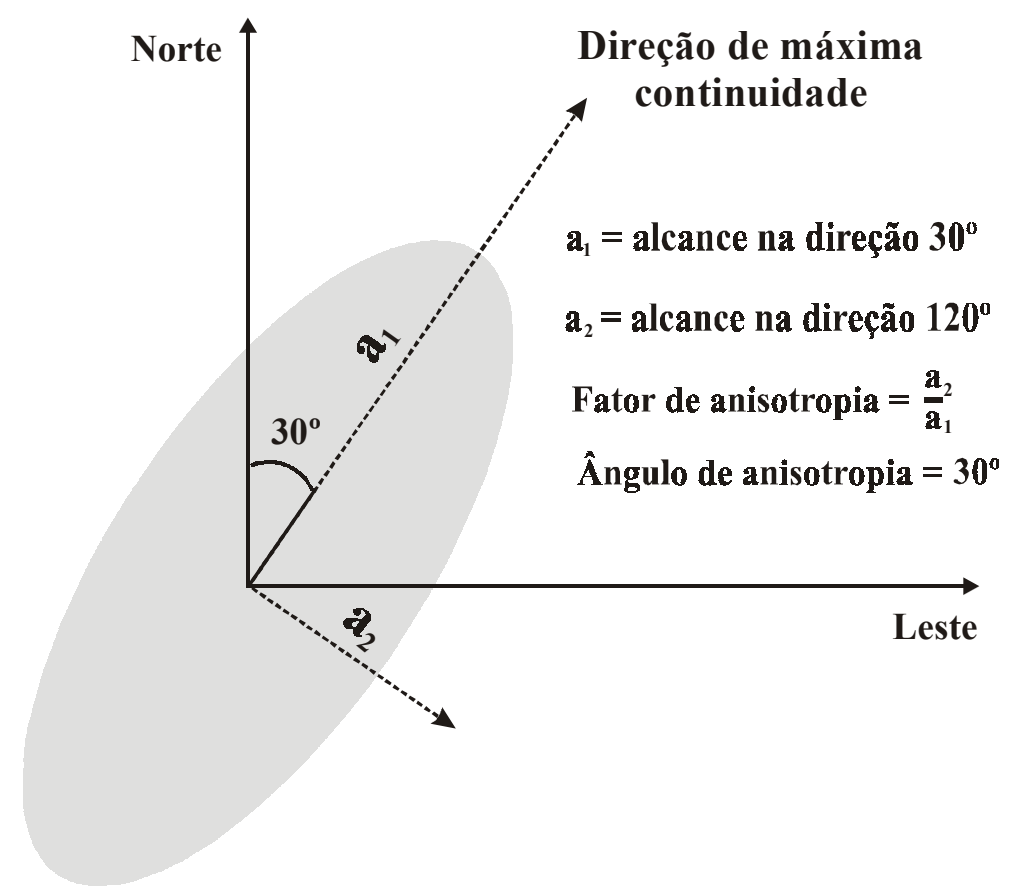

Figura 12 - Representação gráfica da anisotropia geométrica em duas dimensões (Modificado de Deutsch \& Journel, 1992)

Segundo Deutsch \& Journel (1992), o fator de anisotropia geométrica é definido como a razão entre o alcance na direção de menor continuidade $\left(\mathrm{a}_{2}\right)$ e o alcance na direção de maior continuidade $\left(\mathrm{a}_{1}\right)$. Nesse caso, o fator de anisotropia geométrico é sempre menor que a unidade, e o ângulo de anisotropia é igual ao ângulo da direção de máxima continuidade. Existe, ainda, um outro tipo de anisotropia em que os semivariogramas apresentam os mesmos Alcances (a) e diferentes Patamares (C). Nesse caso, a anisotropia é denominada Zonal. Como a isotropia, a anisotropia zonal também é um caso menos freqüente presente nos fenômenos naturais. O mais comum é encontrar combinações da anisotropia Zonal e Geométrica, denominada anisotropia combinada.

Considerando o semivariograma apresentado na Figura 13, os pontos interligados com linhas tracejadas correspondem a semivariogramas experimentais em duas direções ortogonais (Camargo, 1997). O semivariograma com maior patamar (azul) refere-se à direção de $60^{\circ}$ e o aquele com menor patamar (vermelho) refere-se à sua direção perpendicular $\left(150^{\circ}\right)$. Os modelos de ajuste aos semivariogramas estão 
representados por linhas sólidas.

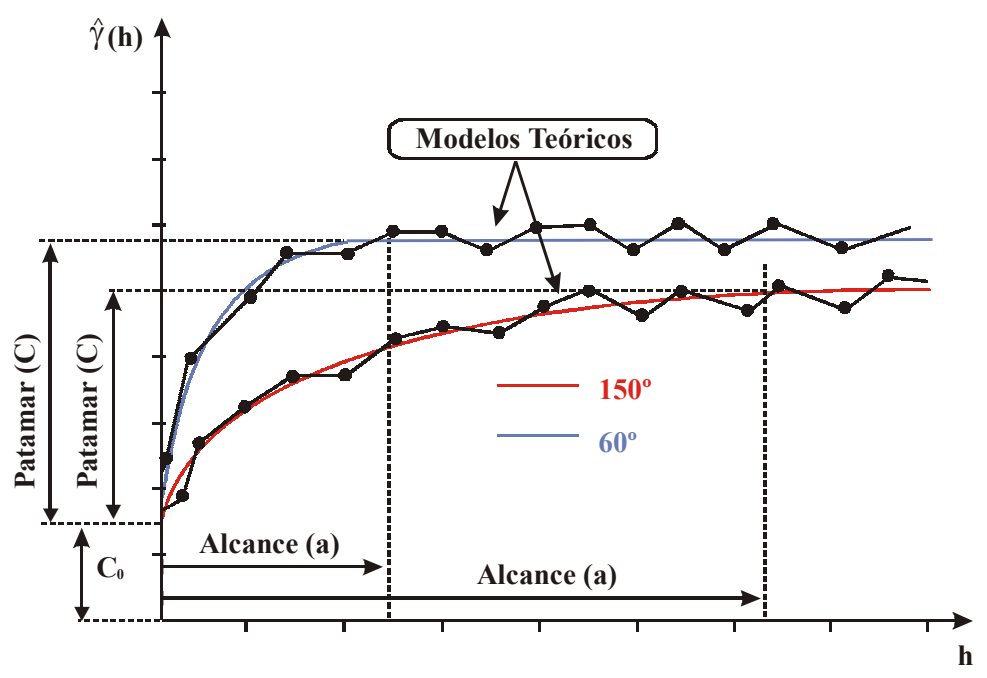

Figura 13 - Representação gráfica de anisotropia combinada (Camargo, 1997)

Segundo Isaaks \& Srivastava ${ }^{2}$, citados por Deutsch \& Journel (1992), a anisotropia zonal pode ser considerada como um caso particular da anisotropia geométrica, ao se supor um fator de anisotropia muito grande. Nessa condição, o alcance implícito na direção de menor continuidade é muito grande. A estrutura do semivariograma é, então, adicionada somente para a direção de maior continuidade.

\subsubsection{Cálculo do semivariograma a partir de amostras regularmente espaçadas}

A Figura 14, conforme apresentada a seguir, considera o conjunto de amostras regularmente espaçadas, em duas dimensões (Camargo, 1997).

2 ISAAKS, E.H.; SRIVASTAVA, R.M. An introduction to applied geostatistics. New York: Oxford University Press, 1989. 561p. 


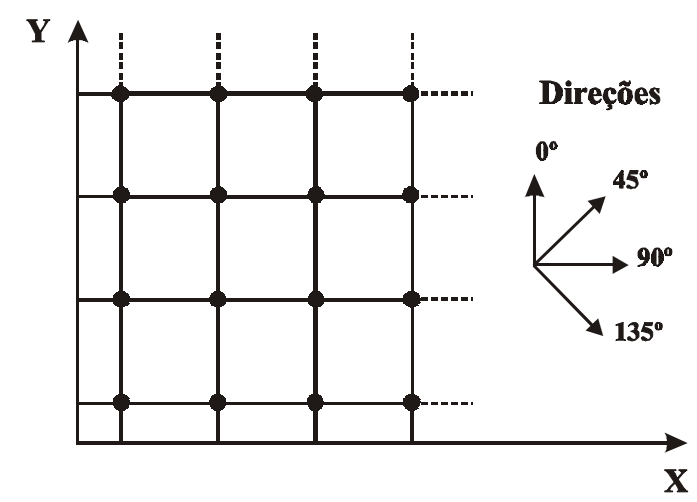

Figura 14 - Amostras regularmente espaçadas em duas dimensões (Camargo, 1997)

Segundo o mesmo autor, para determinar o semivariograma experimental, por exemplo, na direção de $90^{\circ}$ o cálculo de $\hat{\gamma}(h)$ é repetido para todos os intervalos de h. Suponha a distância entre dois pontos consecutivos igual a 100 metros $(d=100 \mathrm{~m})$. Então, qualquer par de observações, na direção $90^{\circ}$, cuja distância é igual a $100 \mathrm{~m}$ será incluído no cálculo de $\hat{\gamma}\left(90^{\circ}, 100 \mathrm{~m}\right)$. Isso feito, os cálculos são repetidos para a próxima distância, por exemplo, 200m, incluindo todos os pares de observações cuja distância é igual a $200 \mathrm{~m}$. O processo é repetido até que algum ponto de parada desejada seja alcançada. O procedimento pode ser mais bem compreendido com o auxílio da Figura 15 e também deve ser realizado para outras direções $\left(0^{\circ}, 45^{\circ}\right.$ e $\left.135^{\circ}\right)$.

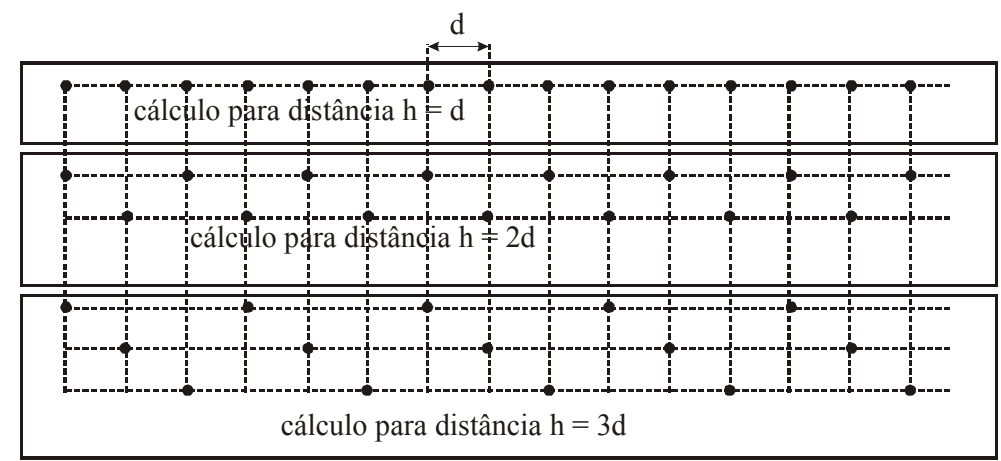

Figura 15 - Ilustração para o cálculo do semivariograma a partir de amostra regularmente espaçadas (Camargo, 1997) 


\subsubsection{Cálculo do semivariograma a partir de amostras irregularmente espaçadas}

De acordo com Deutsch \& Journel (1992), considerando o exemplo de amostras irregularmente espaçadas, em duas dimensões, conforme apresentado na Figura 16, para determinar o semivariograma experimental, é necessário introduzir limites de tolerância para direção e distância.

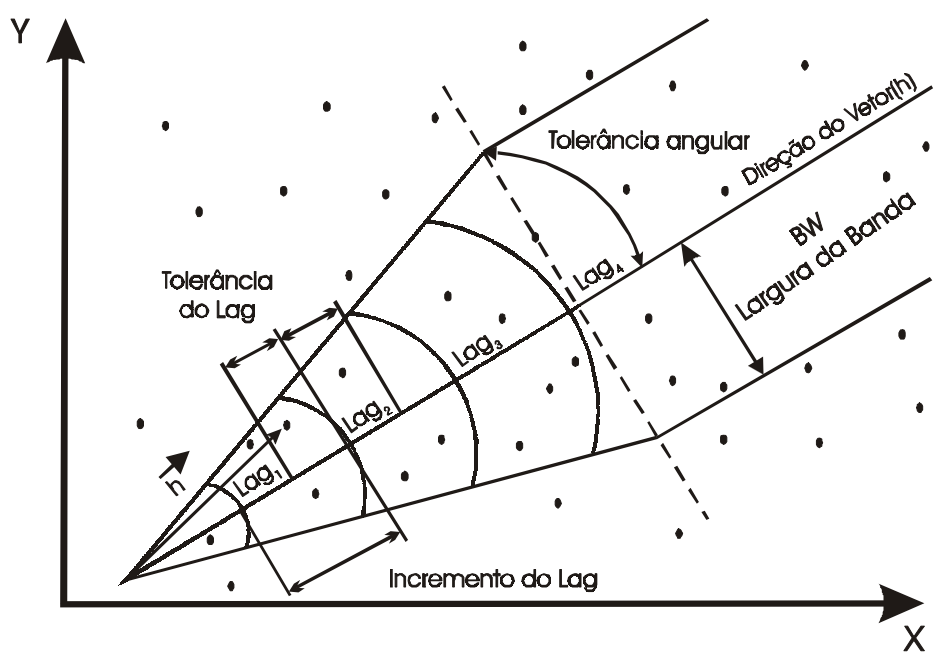

Figura 16 - Parâmetro para o cálculo do semivariograma com base em amostras irregularmente espaçadas em duas dimensões (Modificado de Deutsch \& Journel, 1992)

Segundo Camargo (1997), tomando-se como referência o $\mathrm{Lag}_{2}$ (Lag refere-se a uma distância predefinida, a qual é utilizada no cálculo do semivariograma) da figura acima. Suponha um incremento de Lag igual a 100 metros com tolerância de 50 metros. Considere ainda a direção de medida $45^{\circ}$ com tolerância angular 22,5\%. Então, qualquer par de observações cuja distância está compreendida entre $150 \mathrm{~m}$ e $250 \mathrm{~m}$ e $22,5^{\circ}$ e $67,5^{\circ}$ será incluído no cálculo do semivariograma de $\mathrm{Lag}_{2}$. Esse processo se repete para todos os Lag's.

Conforme o mesmo autor, ainda com referência na Figura 16, a largura de banda (BW) se refere a um valor de ajuste a partir do qual se restringe o número de pares de observações para o cálculo do semivariograma. 


\subsubsection{Validação cruzada}

A etapa de ajuste do modelo ao semivariograma experimental é de grande importância, pois pode influenciar os resultados posteriores. O modelo ajustado deve aproximar-se ao máximo da descrição do fenômeno no campo. Gonçalves et al. (1999) explanam que a verificação do melhor ajuste do modelo teórico ao semivariograma experimental pode ser realizado pela validação cruzada. Resumidamente, o processo de validação envolve a reestimação dos valores conhecidos através dos parâmetros ajustados ao modelo do semivariograma.

Alguns autores, como Vieira et al. (1983), não fazem distinção entre a validação cruzada e a técnica denominada "Jackknife". Segundo Cressie (1991), a validação cruzada consiste em se retirar do conjunto de dados alguns valores e estimálos com base nas observações remanescentes. O erro será obtido pela diferença entre predito e medido. Com várias repetições, pode-se ter uma estimativa da variabilidade do erro de predição. A remoção de observações para melhorar a inferência sobre um parâmetro é denominada "jackknifing", segundo este autor, sendo, portanto, diferente da validação cruzada.

Como a interpolação por krigagem está fortemente associada ao modelo de semivariograma escolhido, a validação cruzada pode ser usada para se decidir qual modelo usar dentre alguns candidatos (Vieira et al., 1981). O usual é a retirada de um dado de cada vez do conjunto original e estimá-lo por krigagem, o que permitirá o cálculo do erro de estimativa nesse ponto, conforme Isaaks \& Srivastava (1989). De acordo com Vieira, (1995), na validação cruzada, procura-se verificar se o erro reduzido, ou seja, o erro em cada ponto dividido pela variância de krigagem correspondente tem média nula e variância unitária, além disso, para uma avaliação visual, têm sido usados mapas de valores medidos versus estimados e mapas de erros, como os fornecidos por programas como GeoEAS (Englund \& Sparks, 1991).

Obtido o semivariograma experimental para um conjunto de valores de uma propriedade e ajustado um modelo matemático a ele, tem-se uma função contínua que descreve a dependência espacial da propriedade, sendo de grande utilidade para a 
compreensão de vários aspectos da variabilidade do solo, da sua formação, implicações no manejo etc. Trangmar et al. (1985) apresentam discussão muito útil sobre essas aplicações. Pode-se dizer que a função de semivariograma descreve uma característica intrínseca àquela propriedade, nas condições estudadas. Essa característica, quantifícada e descrita por um modelo matemático, pode ser usada para, talvez, o mais importante recurso da geoestatística: a interpolação por krigagem.

Segundo Vieira, (1995) e Gonçalves et al. (1999), o semivariograma mais bem ajustado é aquele que possui o maior ajuste dos dados à reta de 45 graus (valores reais versus estimados) obtido pela validação cruzada.

\subsubsection{Interpolação por krigagem}

O termo krigagem tem origem no nome Daniel G. Krige, que foi o pioneiro a introduzir, em 1951, o uso de medidas móveis para evitar a superestimação sistemática de reservas de mineração (Delfiner \& Delhomme, 1975).

O desenvolvimento formal da teoria deve-se a Matheron (1963), para o qual a krigagem é um processo de obtenção do melhor preditor linear não viciado de uma variável desconhecida. Leva em consideração o número de dados e a qualidade deles em cada ponto, a posição dos dados com relação ao campo, a continuidade espacial das variáveis interpoladas e a distância entre os pontos e a área de interesse. Com base em tais observações, constrói-se a melhor função de predição não viciada para cada ponto não observado.

Inicialmente, o método de krigagem foi desenvoldido para solucionar problemas de mapeamentos geológicos, mas seu uso expandiu-se com sucesso no mapeamento de solos (Burgess \& Webster, 1980a,b), mapeamento hidrológico (Kitanidis \& Vomvoris, 1983), mapeamento atmosférico (Lajaunie, 1984) e outros campos correlatos.

Muitos são os métodos de interpolação de valores não amostrados e uma vez que os dados podem ser coletados em um número razoavelmente grande de pontos na área, é pequena a diferença em eficiência de um método para o outro. Mas em muitos 
casos, um número grande de amostras significa um custo muito alto e que não pode ser considerado. Métodos geoestatísticos de interpolação, particularmente o da "krigagem", apresentam propriedades ótimas de estimação em dados esparsos, bem como uma variedade de métodos para tratar diferentes tipos de dados, assim como dados binários (krigagem indicador), dados que apresentam uma suave tendência (krigagem universal) ou mesmo estratificados (krigagem estratificado) (Burrough \& McDonnell, 1998).

Segundo Camargo (1997), a diferença entre a krigagem e outros métodos de interpolação é a maneira como os pesos são atribuídos às diferentes amostras. No caso de interpolação linear simples, por exemplo, os pesos são todos iguais a $1 / N(N=$ número de amostras); na interpolação baseada no inverso do quadrado das distâncias, os pesos são definidos com o inverso do quadrado da distância que separa o valor interpolado dos valores observados. Na krigagem, o procedimento é semelhante ao de interpolação por média móvel ponderada, exceto que aqui os pesos são determinados com base em uma análise espacial, baseada no semivariograma experimental. Além disso, a krigagem fornece, em média, estimativas não tendenciosas e com variância

mínima. Estimativas não tendenciosas significam que, em média, a diferença entre valores estimados e verdadeiros para o mesmo ponto deve ser nula; e variância mínima significa que esses estimadores possuem a menor variância dentre todos os estimadores não tendenciosos.

Segundo Oliver \& Webster (1990), a krigagem engloba um conjunto de métodos de estimativa, esse trabalho limita-se somente à krigagem ordinária em bloco, a qual será descrita a seguir.

\subsubsection{Krigagem ordinária em blocos}

Muito comum em problemas de mineração, às vezes o interesse é na estimativa da média do valor de uma propriedade em uma certa região. Uma alternativa é discretizar essa subárea em muitos pontos, fazer a krigagem pontual e depois tomar-se a média dos valores, o que se torna trabalhoso. Outra forma é o uso da krigagem em blocos, que fornece um valor médio para a região e segundo Isaaks \& Srivastava (1989), 
produz estimativa idêntica àquela resultante dos valores produzidos pela krigagem ordinária.

A krigagem em blocos se baseia na mesma equação do estimador da krigagem pontual, mudando apenas a forma de se determinarem os pesos (Trangmar et al., 1985). No lugar da semivariância entre pontos amostrais e ponto estimado, usa-se a semivariância média entre pontos amostrais e todos os pontos dentro do bloco $\left[\gamma\left(x_{i}, V\right)\right]$. A variância de estimativa mínima para o bloco $V$ é dada por:

$$
\sigma_{V}^{2}=\sum_{i=1}^{n} \lambda_{i} \gamma\left(x_{i}, V\right)+\mu_{V}-\gamma(V, V)
$$

sendo:

$$
\sum_{i=1}^{n} \lambda_{i}=\text { Média dos pesos correspondentes aos valores } x_{i} \text { na vizinhança do }
$$

bloco;

$$
\gamma\left(x_{i}, V\right)=\text { Semivariância média entre os pontos amostrais } x_{i} \text { na vizinhança e }
$$
aqueles no bloco $V$;

$\mu_{V}=$ Parâmetro de Lagrangian associado à minimização e

$\gamma(V, V)=$ Semivariância média entre todos os pontos dentro do bloco $V$ (isto é, a variância dentro do bloco da estatística clássica).

A subtração da semivariância média entre todos os pontos dentro do bloco $V$, torna a variância da estimativa na krigagem em blocos menor que na krigagem pontual, o que favorece a sua utilização. $\mathrm{O}$ uso da krigagem em blocos na produção de mapas de isolinhas de propriedades do solo, como em Burgess \& Webster (1980b); apresenta o efeito de suavizar descontinuidades locais e tem sido o uso mais comum (Trangmar et al., 1985). 


\section{MATERIAL E MÉTODOS}

\subsection{Caracterização da área experimental}

O ensaio foi conduzido no município de Rancharia, no estado de São Paulo Brasil, cujas coordenadas geográficas do ponto central (número 97) da área experimental são: latitude $22^{\circ} 37^{\prime}$ 54” S e longitude $50^{\circ} 54^{\prime} 29^{\prime}$ ' W.

O solo é classificado como Latossolo Vermelho Amarelo Distrófico, A moderado, textura média e relevo suave ondulado.

Segundo a classificação de Köppen (1948), o clima predominante na região é caracterizado como Cwa, especificado como subtropical com verão chuvoso e inverno seco. A temperatura média anual é de $26^{\circ} \mathrm{C}$, sendo que a média das mínimas alcança $18^{\circ} \mathrm{C}$ em julho e a média das máximas atinge $33,6^{\circ} \mathrm{C}$ em fevereiro. A precipitação média anual é de $1.400 \mathrm{~mm}$.

A Figura 17 ilustra a área do experimento, a área total do cultivar. A Figura 18 representa a área experimental com uma declividade aproximada de 5,5\%. 


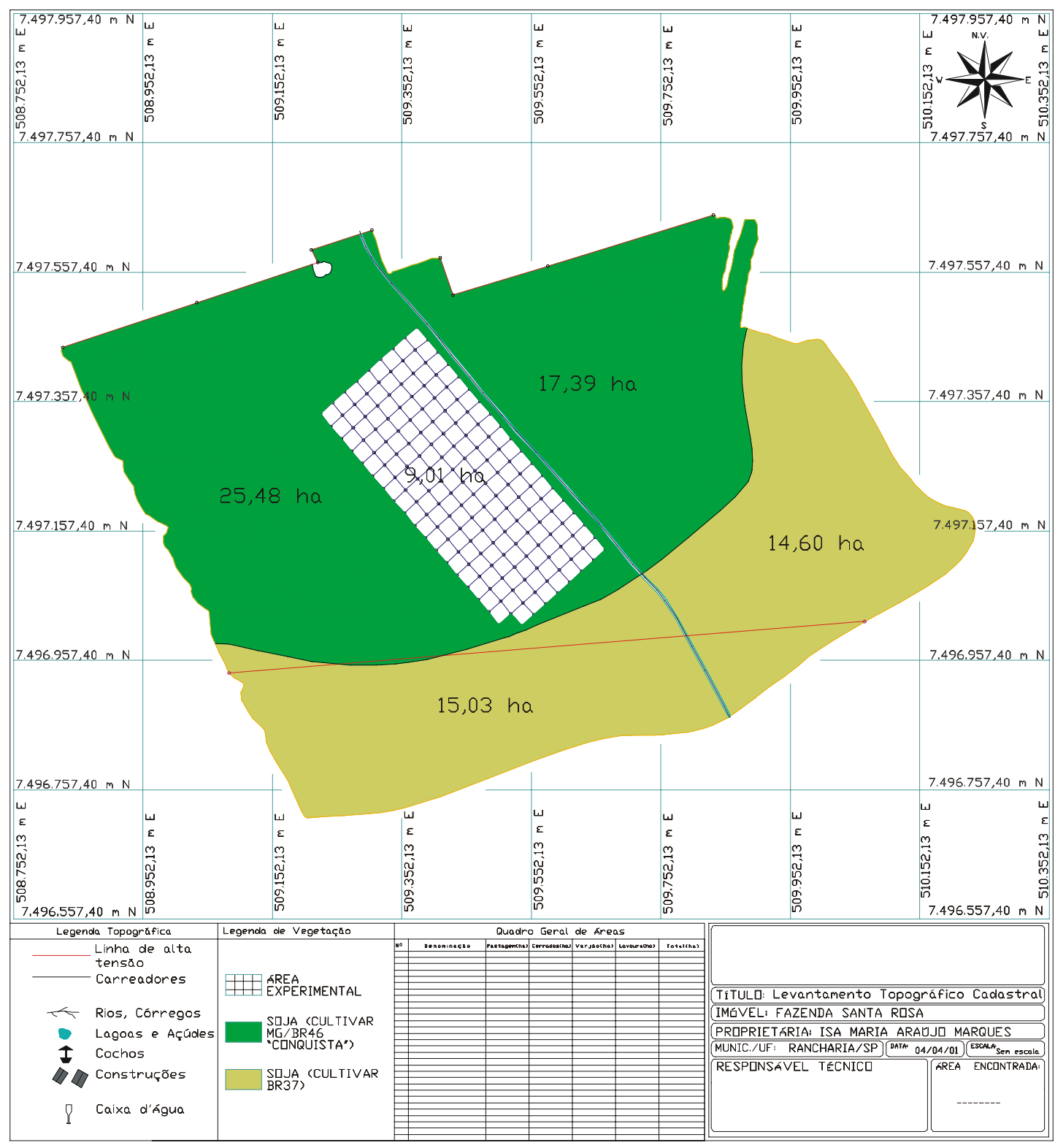

Figura 17 - Ilustração da disposição da área experimental 


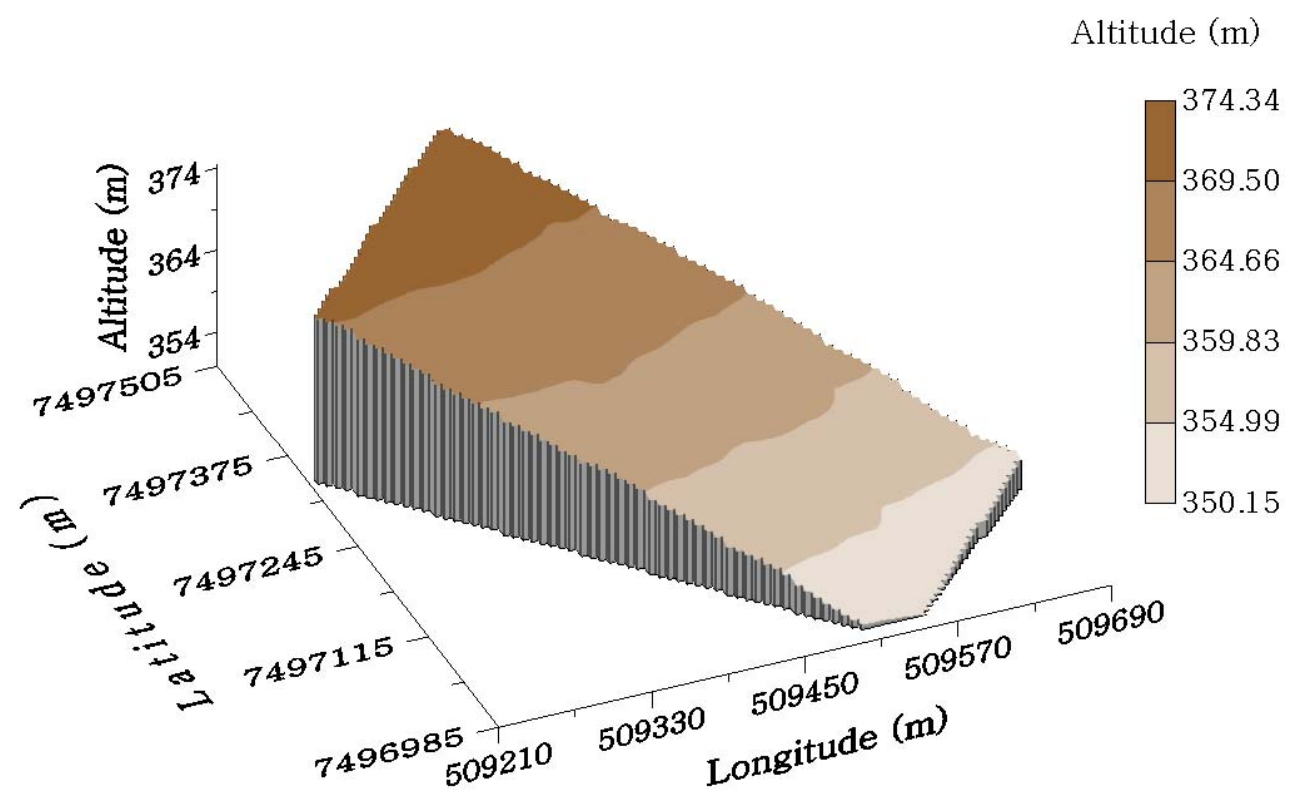

Figura 18 - Ilustração da declividade da área experimental (Altitude Geométrica)

A área experimental, nos últimos 10 anos, encontrava-se sob pastoreio intensivo, com o capim braquiária (Brachiaria Brizantha). Um mês antes do plantio da soja (Glycine max L.), foi aplicado o herbicida Glyphosate (Roundup W.G.), na dose de 3,5 kg.ha ${ }^{-1}$ do produto comercial, para semear a soja no sistema de plantio direto. Esse herbicida é recomendado para o controle não seletivo de mono e dicotiledôneas em pósemergência de diversas culturas e para o manejo do sistema de plantio direto (Rodrigues \& Almeida, 1998).

A soja utilizada nesse estudo era do cultivar MG/BR 46 (Conquista), semeada no dia 8 de dezembro de 2000; de uma área total de 51,88ha, foi escolhida uma área com 9,01ha para coleta das amostras. A cultura foi implantada com um espaçamento de $45 \mathrm{~cm}$ e uma densidade de 22 sementes por metro, para um "stand" final de 355.555 plantas $\mathrm{ha}^{-1}$ (aproximadamente 16 plantas por metro). A cultura foi adubada com $\mathrm{N}, \mathrm{P}_{2} \mathrm{O}_{5}$ e $\mathrm{K}_{2} \mathrm{O}$ nas proporções de 5,4, 54 e $54 \mathrm{~kg} \cdot \mathrm{ha}^{-1}$ respectivamente $\left(270 \mathrm{~kg} \cdot \mathrm{ha}^{-1}\right.$ da fórmula 2-20-20, com 30kg de FTE BR-12 por tonelada deste adubo) e produziu em média 2.653kg.ha ${ }^{-1}$. Os grãos utilizados nas análises foram colhidos nos dias 4, 5 e 6 de abril de 2001 e 
debulhados manualmente nos dias 8, 9 e 10 .

\subsection{Esquema experimental de amostragem da soja e do solo}

As amostras de grãos de soja e solo, utilizadas para análises em laboratório, foram colhidas em pontos correspondentes aos nós de uma malha regular de $25 \mathrm{~m}$ x $25 \mathrm{~m}$, perfazendo 170 amostras na área experimental, como ilustra a Figura 20. Em cada ponto amostral, num raio de $1 \mathrm{~m}$ ao redor do ponto central georreferenciado, foram colhidas todas as plantas de soja (aproximadamente 100 plantas por ponto) e colocadas em sacos de ráfia. Depois de proceder a debulha manual, foram retiradas amostras de $0,30 \mathrm{~kg}$ de grãos de soja de cada saco de ráfia, as quais foram colocadas em sacos de papel e levadas ao laboratório para análise dos teores de óleo (\%E.E.M.S.) e proteína (\%P.B.M.S.). Nesse mesmo raio foram coletadas 7 subamostras (Chitolina et al., 1995) de solo a profundidade de 0-0,20m em posições aleatórias (Raij et al., 1985), retirandose apenas do terço central da rua da cultura (Figura 19) para que o adubo de plantio não interferisse nos resultados das análises químicas (Instituto Agronômico do Paraná, 1996), totalizando uma amostra composta com 0,45kg. Essa amostra foi colocada em sacos plásticos específicos para amostra de solo, identificados pelo número do ponto amostral e levados ao laboratório para se fazer a análise química (macro e micro nutrientes) e a física (areia, silte e argila). 


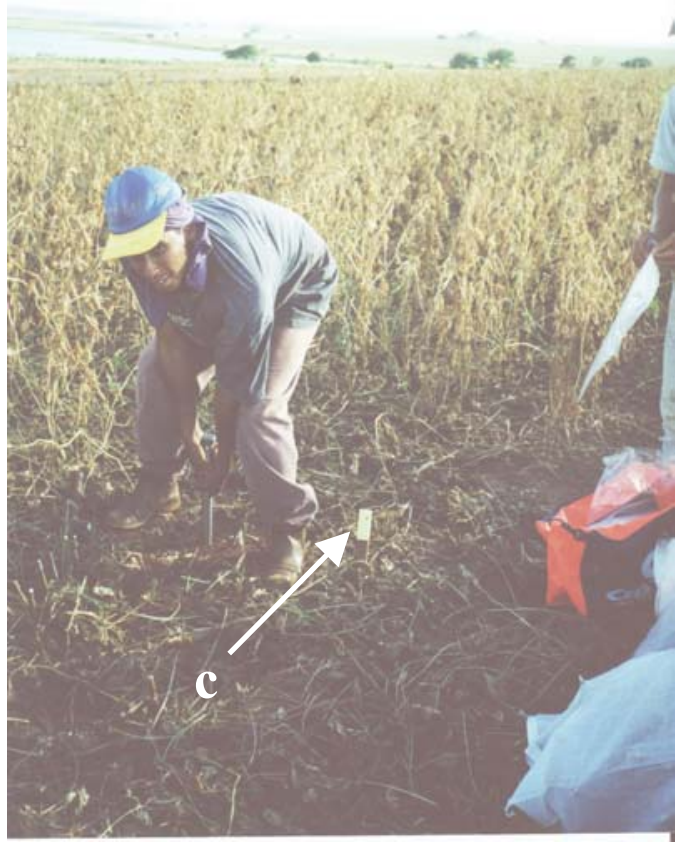

(a)

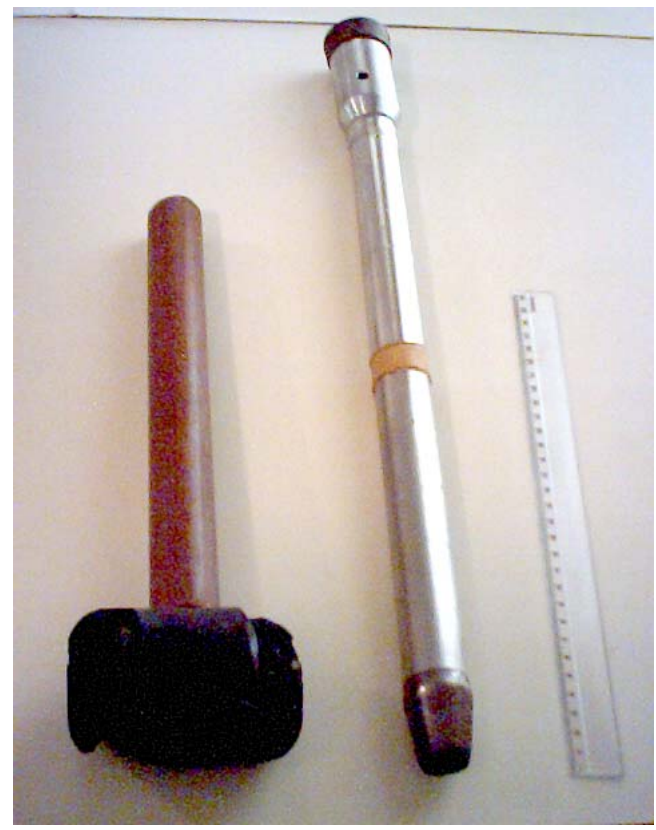

(b)

Figura 19 - Ilustração da amostragem de solo: a) Retirada de uma subamostra próximo (máximo $1 \mathrm{~m}$ ) e ao redor do ponto georreferenciado; b) Equipamento utilizado para retirada das amostras de solo e c) Ponto georreferenciado

Os nós da malha foram marcados com uma estaca numerada (Figura 19c) e cada amostra (solo e soja) referente a esse marco levava a mesma numeração para o laboratório. A Figura 20 ilustra a disposição dos pontos amostrais georreferenciados utilizados para mapeamento de atributos da soja e do solo. 


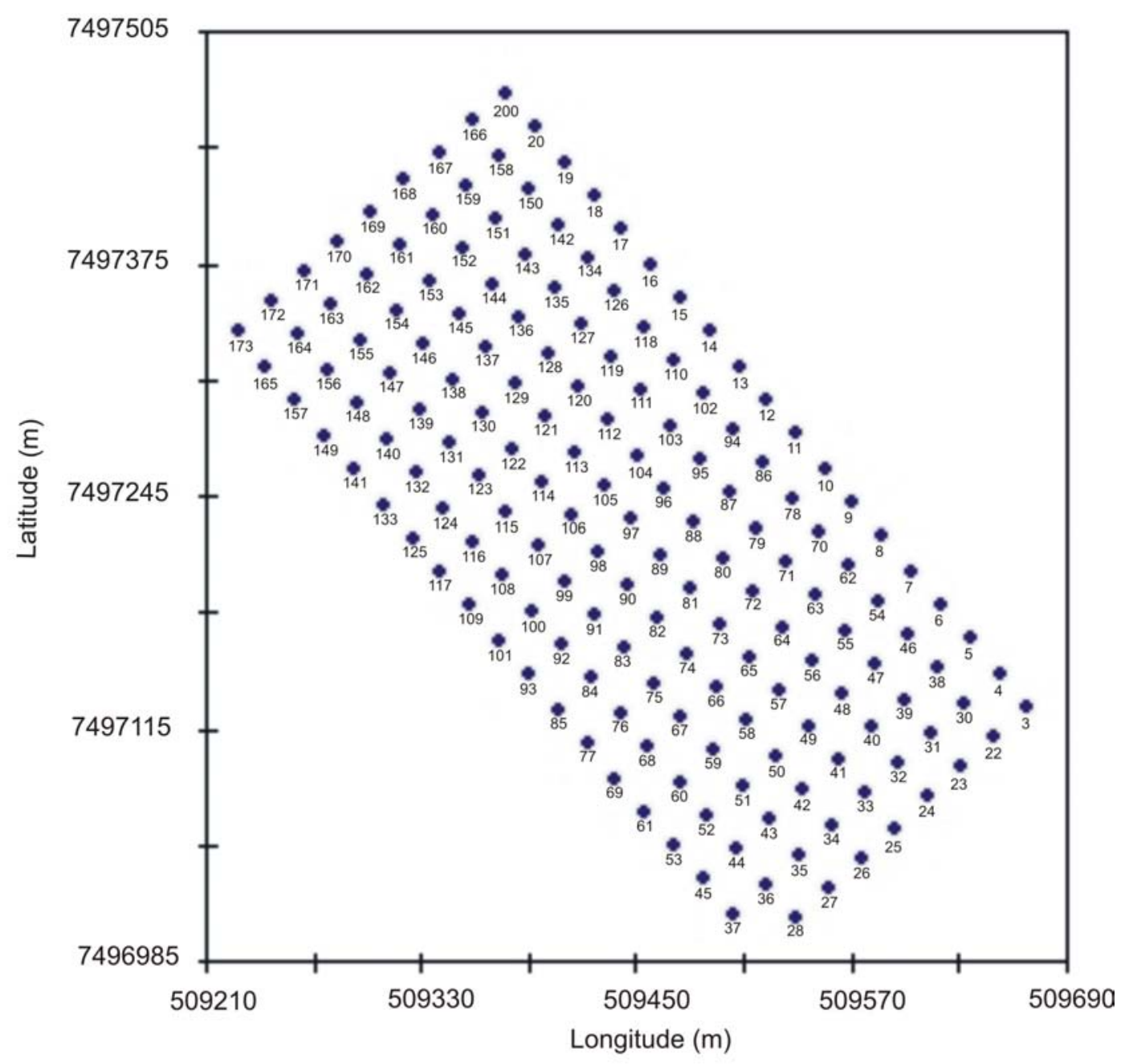

Figura 20 - Ilustração da malha de pontos com a sua numeração

As amostras de soja e solo foram enviadas para o laboratório de análise de solos e tecido vegetal da Faculdade de Ciências Agrárias da Unoeste, em Presidente Prudente - SP. Foram realizadas as análises bromatológicas das sementes de soja (\%E.E.M.S. e \%P.B.M.S.), seguindo a metodologia da A.O.A.C. (Association of Official Agricultural Chemists). As análises granulométricas foram efetuadas pelo método da pipeta, segundo Camargo et al. (1986); já as análises químicas de solo foram feitas pelo métodos recomendados por Raij et al. (1987). 


\subsection{Sistema de Posicionamento Global - GPS}

O "grid" foi inicialmente marcado com uma Trena de fibra de vidro marca Komwlon, modelo KMC-1600 (30m) e duas cordas de náilon de $16 \mathrm{~mm}$, uma com 50m e outra com 100m (Figura 21). Posteriormente, cada marco e a área total foram georreferenciados por meio de DGPS da marca Trimble, modelo Pro-XR, capacidade de leitura de 12 canais, bastão telescópico CST e bipé extensível para bastão (Figura 21). Para se fazer a correção diferencial dos marcos e da área foi utilizada a base da Empresa Santiago \& Cintra, da marca Trimble, com receptor TRS de 12 canais, localizado no município de Quatá, no estado de São Paulo (distância da base ao móvel 49km aproximadamente), cujas coordenadas geográficas são: Latitude $22^{\circ} 15^{\prime} 47,15144^{\prime}$ S , Longitude $50^{\circ} 38^{\prime} 58,52174$ " W e altitude de 529,955m (HAE), com taxa de gravação de 5 segundos. Este receptor DGPS utilizou o código C/A (“Coarse/Acquisition”) para o posicionamento; foi escolhido esse método porque o equipamentos utilizado (GPS) não proporcionava a correção em tempo real (Real-time), na qual o receptor base transmite as correções e o receptor móvel aplica as mesmas (DGPS). 


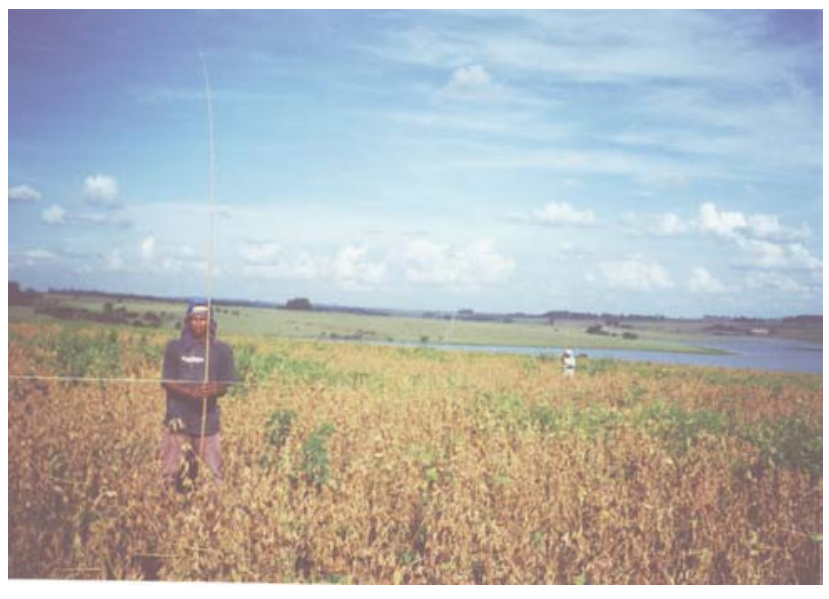

(a)

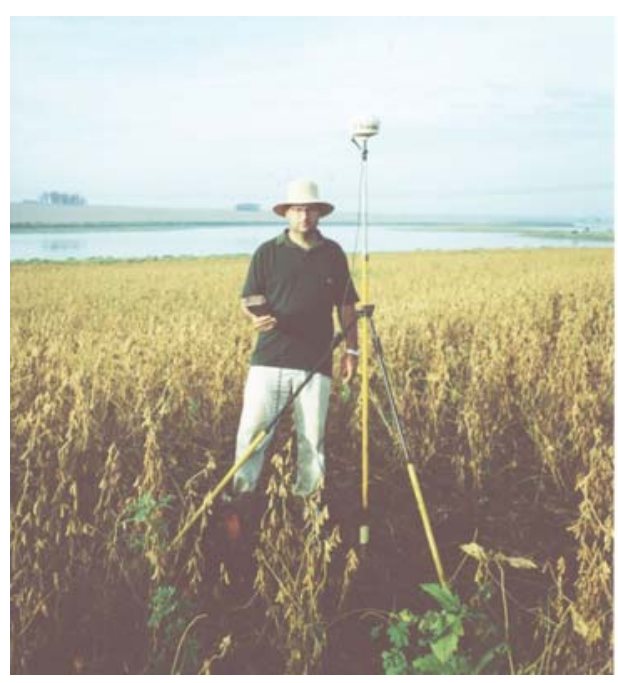

(b)

Figura 21 - Ilustração do método utilizado para marcação do "grid" amostral: a) Marcação com corda de náilon; b) Ponto do "grid" amostral sendo georreferenciado

Todos os mapas gerados foram georreferenciados segundo o "datum" WGS-84. Esses mapas possuíam coordenadas geográficas que foram transformadas para o sistema de coordenadas UTM (Universal Transverso de Mercator). Todos os mapas ilustrados neste trabalho estão georreferenciados no sistema de coordenadas UTM.

A área em estudo não oferecia obstruções físicas para o recebimento dos sinais dos satélites pelo DGPS.

\subsection{Programas computacionais}

Para o mapeamento da grade amostral, para o levantamento da área plantada e do perímetro, foi utilizado o programa AutoCAD 2000. A tabulação dos dados foi realizada pela planilha eletrônica Excel (Microsoft Inc.) versão 2000.

O programa estatístico Minitab, versão 13.2 (Minitab Institute Inc.), foi utilizado para todos os cálculos estatísticos, para a realização dos cálculos das correlações e encontrar modelo de regressão linear múltipla dos teores de óleo e proteína 
com os atributos da fertilidade e granulometria do solo.

A análise geoestatística foi realizada com o auxílio do programa GS+ (Gamma Design Software) versão 5.3.1. O mapa em três dimensões, representando a altitude da área experimental com a representação da superfície de cada variável em estudo, foi realizado com auxílio do programa GS+ e Surfer 8.0.

\subsection{Atributos da soja}

\subsubsection{Análise da porcentagem do extrato etéreo na matéria seca (\%E.E.M.S.) da soja}

O método utilizado foi o método a quente (A.O.A.C., 1984), no qual o éter usado no processo é aquecido até tornar-se volátil e, ao condensar-se, circula sobre a amostra em análise, arrastando toda a fração gordurosa e demais substâncias solúveis em éter, que é recuperado em outro recipiente, enquanto a gordura extraída é calculada por diferença de pesagem.

\subsubsection{Análise da porcentagem da proteína bruta na matéria seca (\%P.B.M.S.) da soja}

O método de Kjeldahl (A.O.A.C., 1984) utilizado neste trabalho tem passado por modificações e desde então, até hoje, é o mais amplamente adotado e o mais indicado para amostras de origem biológica. Nesse método, por meio de uma digestão ácida, o nitrogênio da amostra é transformado em amônio $\left(\mathrm{NH}_{4}{ }^{+}\right)$, o qual é posteriormente separado por destilação e finalmente dosado pela titulação. O método é basicamente dividido em três etapas:

1. Digestão - o nitrogênio orgânico é transformado em amônia e os compostos orgânicos são convertidos em $\mathrm{CO}_{2}, \mathrm{H}_{2} \mathrm{O}$ etc.

2. Destilação - em que a amônia é separada e reconhecida em uma solução 
receptora (ácido bórico).

3. Titulação - determinação quantitativa da amônia contida na solução receptora. Dependendo da técnica, a separação da amônia é omitida, fazendo-se a sua determinação diretamente no material, após a digestão.

Esse método baseia-se na transformação do nitrogênio da amostra em sulfato de amônio, por digestão ácida, e em nitrogênio amoniacal por destilação em meio alcalino.

As proteínas e outros compostos nitrogenados são decompostos na presença do ácido sulfúrico concentrado, a quente, com produção de sulfato de amônio. O sulfato de potássio ou de sódio é adicionado, a fim de aumentar o ponto de ebulição do ácido sulfúrico, apressando a digestão. Outros compostos como sulfato de cobre, selênio, etc, também ajudam, durante a digestão da matéria orgânica.

O sulfato de amônio resultante, na presença da solução concentrada de hidróxido de sódio, libera $\mathrm{NH}_{3}$ que é recebido na solução de ácido bórico. A amônia, na solução de ácido bórico, é titulada com ácido sulfúrico ou clorídrico de título conhecido e, assim, determina-se o teor de nitrogênio da amostra.

\subsection{Atributos do solo}

\subsubsection{Análise de fertilidade}

As 170 amostras de solo correspondem à camada de 0 a $0,2 \mathrm{~m}$ de profundidade e foram separadas e enviadas ao Laboratório de Análise de Solos e Tecido Vegetal da Faculdade de Ciências Agrárias da Unoeste, para serem analisadas. Essa profundidade foi a escolhida porque é nela que a maior parte das raízes se concentra (Barreto et al. 1974; Miranda, 1982; Raij et al., 1985; Jorge, 1986; Boaretto, 1988). As amostras foram analisadas para determinar a característica química de: $\mathrm{pH} \mathrm{CaCl}_{2}$ e os teores de acidez potencial (H+Al); alumínio (Al); matéria orgânica (M.O.); cálcio (Ca); magnésio $(\mathrm{Mg})$;

potássio $(\mathrm{K})$; fósforo $(\mathrm{P})$; enxofre $(\mathrm{S})$; manganês $(\mathrm{Mn})$; ferro $(\mathrm{Fe})$; cobre $(\mathrm{Cu})$; zinco $(\mathrm{Zn})$ 
e boro (B), e obtidos por cálculos os seguintes parâmetros: soma de bases (SB); capacidade de troca de cátions (CTC); porcentagem de saturação por bases (V\%) e porcentagem de saturação por alumínio (m\%). Para o cálculo de SB, CTC, V\% e m\%, utilizou-se as seguintes equações:

$$
\begin{aligned}
& \mathrm{SB}=\mathrm{Ca}+\mathrm{Mg}+\mathrm{K} ; \mathrm{CTC}=\mathrm{SB}+(\mathrm{H}+\mathrm{Al}) \\
& \mathrm{V} \%=\frac{100 . S B}{C T C} \quad \text { e } \mathrm{m} \%=\frac{100 \cdot A l}{(S B+A l)}
\end{aligned}
$$

Os resultados obtidos correspondem às seguintes unidades:

$\mathbf{m m o l}_{\mathbf{c} \cdot \mathbf{d m}} \mathbf{d m}^{\mathbf{3}}=\operatorname{acidez}$ potencial $(\mathrm{H}+\mathrm{Al})$; alumínio $(\mathrm{Al})$; cálcio $(\mathrm{Ca})$; magnésio $(\mathrm{Mg})$; potássio $(\mathrm{K})$; soma de bases (SB) e capacidade de troca de cátions (CTC).

$\%=$ porcentagem de saturação por alumínio $(\mathrm{m} \%)$ e porcentagem de saturação por bases $(\mathrm{V} \%)$.

g.dm $\mathbf{~}^{-3}=$ matéria orgânica (M.O.).

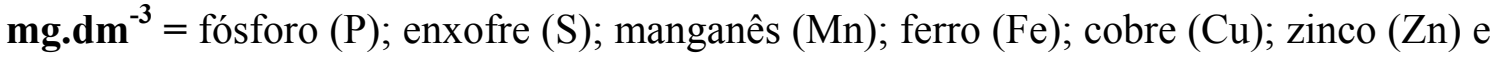
boro (B).

sem unidade: $\mathrm{pH} \mathrm{CaCl}_{2}$.

\subsubsection{Análise granulométrica}

Para fazer a análise granulométrica foram utilizadas as mesmas 170 amostras utilizadas para se fazer a análise de fertilidade. Foram coletadas no mesmo dia da colheita da soja e num clima e solo bastante seco na ocasião. Essa análise (método da pipetagem) foi feita no mesmo laboratório mencionado no item anterior e o procedimento adotado para a análise granulométrica dos teores de areia $\left(\mathrm{g}_{\mathrm{kg}} \mathrm{kg}^{-1}\right)$, argila (g. $\left.\mathrm{kg}^{-1}\right)$ e silte (g. $\left.\mathrm{kg}^{-1}\right)$ de cada amostra segue o padrão recomendado por Camargo et al. (1986). 


\subsection{Análise dos dados}

\subsubsection{Análise estatística dos dados amostrados}

Com os dados dos atributos da soja e do solo, foi realizado um resumo estatístico, com medidas de posição e dispersão, e uma análise exploratória dos dados, utilizando a parte estatística do programa Excel 2000 e o pacote estatístico Minitab, versão 13.2 (Minitab Institute Inc.).

Foram realizadas as análises de medidas de posição (média, valores máximo e mínimo, quartis superior e inferior), de dispersão (desvio padrão e variância) e da forma da dispersão (simetria e curtose). O cálculo dos momentos de terceira e de quarta ordens (simetria e curtose) permitiu a caracterização das curvas normais das variáveis mensuradas.

Preston (1970) estabeleceu um teste de normalidade dos dados, com base nas curvas e tabelas de Pearson \& Hartley (1966). De acordo com esse teste, os dados seguem uma distribuição normal, se as seguintes medidas, assimetria, curtose e a relação $\mathrm{A} / \mathrm{s}$ (amplitude total dos dados sobre desvio padrão) estiverem dentro dos intervalos associados para cada variável, no caso deste trabalho, o menor " $n$ " (número de amostras) que se pode encontrar é o da variável argila (147) e o maior para variável boro (170), os limites de valores foram interpolados do ábaco sugerido por Preston, (1970).

O cálculo dos quartis da distribuição dos valores das variáveis mensuradas auxiliou na identificação dos dados discrepantes da distribuição normal ("outliers"). O cálculo para a identificação dos dados candidatos a dados discrepantes foi realizado pelo critério dos limites inferior e superior de uma distribuição normal (Libardi et al., 1996 e Gonçalves et al., 1999). Os limites superior e inferior foram obtidos pelas equações:

$$
\begin{aligned}
& \mathrm{AI}=\mathrm{QS}-\mathrm{QI} \\
& \mathrm{LS}=\mathrm{QS}+(1,5 . \mathrm{AI}) \\
& \mathrm{LI}=\mathrm{QI}-(1,5 . \mathrm{AI})
\end{aligned}
$$


sendo:
AI é a Amplitude Interquartil;
LS é o Limite Superior
LI é o Limite Inferior;
QS e QI são os Quartis Superior e Inferior.

Os dados que não se enquadravam entre os limites inferior e superior foram considerados dados discrepantes (“outliers"). Toda análise estatística foi refeita sem os dados discrepantes (“outliers").

\subsubsection{Análise de regressão linear múltipla}

Nesta parte do trabalho, foi utilizada a técnica de regressão múltipla, que testa as dependências cumulativas de uma única variável dependente em relação a diversas variáveis independentes, onde cada variável é separada e mantida constante enquanto as restantes variam sistematicamente, sendo observados os seus efeitos e a sua contribuição sobre a variável dependente. A variável a ser isolada é aquela que apresenta a maior influência na variabilidade da variável dependente.

O modelo é apresentado a seguir:

$$
\mathrm{y}_{\mathrm{i}}=\alpha_{0}+\alpha_{1 \mathrm{x}_{1 \mathrm{i}}}+\ldots \ldots+\alpha_{\mathrm{m}} \mathrm{x}_{\mathrm{mi}}+\varepsilon_{\mathrm{i}}
$$

onde os $\alpha_{\mathrm{i}}$ são constantes desconhecidas a serem determinadas e $\varepsilon_{\mathrm{i}}$ representa toda a fonte de variabilidade em "y" não explicada por " $\mathrm{x}$ ". A variável "x" é considerada independente e a "y" é considerada dependente.

A proporção da variância dos "y" observados, explicada por uma equação de regressão ajustada, é representada pelo coeficiente de determinação $r^{2}$. Os valores de $r^{2}$ se apresentam num intervalo de $0-1$, fornecendo uma medida dimensional da quantidade 
do ajuste do modelo de regressão múltipla dos dados. Quando o valor de $r^{2}$ apresenta valores próximos de 1 , significa que as diversas variáveis utilizadas no modelo de regressão são responsáveis quase que totalmente pela variabilidade de "y".

O modelo de regressão linear múltipla foi encontrado somente com os dados dos pontos georreferenciados, onde não existiam dados discrepantes de nenhuma variável (total de 23 variáveis), sendo as variáveis óleo (\%E.E.M.S.) e proteína (\%P.B.M.S.) consideradas dependentes e o restante independente. De 170 pontos, 103 não foram considerados dados discrepantes (“outliers”).

Como as variáveis óleo (\%E.E.M.S.) e proteína (\%P.B.M.S.) não tiveram dependência espacial, resolveu-se fazer a interpolação dos dados pelo método do inverso do quadrado da distância (Vieira et al. 1983) para fazer a interpolação dos valores, para depois fazer a regressão pelo Idrisi32 desses mapas interpolados com as variáveis que melhor ajustamento deram na estatística convencional.

\subsubsection{Análise geoestatística dos dados amostrados}

Toda análise geoestatística foi feita sem os dados discrepantes (“outliers"), no programa GS+, versão 5.3.1.

Com os dados das variáveis mapeadas (óleo e proteína da soja; fertilidade e granulometria do solo) foram obtidos os semivariogramas teóricos, que são curvas ajustadas que proporcionam a máxima correlação entre os pontos dos semivariogramas experimentais. O programa GS+ realizou a escolha do melhor modelo do semivariograma teórico baseado na minimização da soma dos quadrados dos resíduos, em relação aos pontos do semivariograma experimental. Foram avaliados os modelos de semivariogramas esférico, exponencial, gaussiano e linear. Foram analisados os modelos dos semivariogramas isotrópicos e anisotrópicos para as variáveis mensuradas.

O processo de validação do modelo é uma etapa que precede as técnicas de krigagem. Seu principal objetivo é avaliar a adequação do modelo proposto no processo que envolve a reestimação dos valores amostrais conhecidos.

A escolha do melhor modelo de semivariograma teórico ajustado foi através do 
maior valor do ajuste $\left(\mathrm{R}^{2}\right)$ da reta obtida, com a reta pontilhada a 45 graus, obtido pela validação cruzada (valores lidos versus valores estimados), foi o fator que mais influenciou na escolha do modelo (Vieira, 1995). Em caso de igualdade entre os resultados da validação cruzada para uma determinada variável, o modelo escolhido foi o que possuía o menor efeito pepita, pois esse fator ilustra o quanto da variabilidade espacial não está sendo descrita pelo modelo.

Após o ajuste dos semivariogramas teóricos, foram tomados todos os parâmetros necessários para a realização da interpolação dos mapas pelo processo de krigagem, utilizando-se os parâmetros dos semivariogramas calculados.

Também foi calculada a relação entre o efeito pepita e o patamar $(\mathrm{Co} / \mathrm{Co}+\mathrm{C})$ para cada modelo ajustado. Definiu-se, aqui, que uma dependência espacial é forte quando o efeito pepita corresponde a um valor menor ou igual a $25 \%$ do patamar, dependência espacial moderada, quando o efeito pepita corresponde a um valor maior que $25 \%$ e menor ou igual a $75 \%$, e fraca quando maior que $75 \%$ do patamar (Cambardella et al., 1994). Portanto, quanto menor essa relação, menos o efeito pepita está influenciando a dependência espacial dos dados.

\subsubsection{Interpolação dos dados amostrados}

Os parâmetros dos modelos dos semivariogramas obtidos pela análise geoestatística foram utilizados para a realização da interpolação dos dados por krigagem. O tipo de krigagem escolhido para a realização da interpolação das variáveis mapeadas foi a krigagem ordinária em blocos 4 x 4. A krigagem ordinária leva em consideração a estacionaridade (dispersão em torno da média homogênea) somente nas vizinhanças do ponto amostral (hipótese intrínseca), sem a perda de informações em relação à krigagem simples. Em blocos é mais adequada, pois não perde em qualidade em relação à pontual, reduz a variância de krigagem e proporciona uma estimativa mais confiável (Gonçalves et al., 1999).

No programa GS+ foi criado um arquivo com extensão .GRD da interpolação por krigagem que gerou um mapa em duas dimensões, para depois ser importado pelo 
programa Surfer 8.0 e fazer a sobreposição ("overlay") com o mapa da altitude em três dimensões gerado no Surfer. Os mapas foram georreferenciados no sistema de coordenadas UTM.

Foi feita a regressão pelo programa Idrisi32, dos mapas interpolados por krigagem das variáveis que se mostraram com uma classificação da posição de valores semelhantes. 


\section{RESULTADOS E DISCUSSÃO}

\subsection{Análises descritivas e exploratórias}

Dando início aos estudos das variáveis observadas nos pontos de coleta de amostra, foi elaborada a matriz de correlação dessas variáveis, conforme se pode observar na Tabela 2.

Tabela 2. Matriz de coeficientes de correlação de Pearson entre as 24 variáveis em estudo $(n=170)$

\begin{tabular}{|c|c|c|c|c|c|c|c|c|c|c|c|c|}
\hline is & E.F & \%P.B.M.S. & Areia & Argila & Silte & $\mathrm{pH} \mathrm{CaCl}{ }_{2}$ & $\mathbf{H}+\mathbf{A l}$ & Al & M.O. & $\mathrm{Ca}$ & Mg & $\mathbf{K}$ \\
\hline \%E.E.M.S. & $\mathbf{1 , 0 0}$ & $0,01^{\mathrm{ns}}$ & $-0,10^{\mathrm{ns}}$ & $0,12^{\mathrm{ns}}$ & $01 \mathrm{~ns}$ & $0,09^{\mathrm{ns}}$ & $-0,02^{\mathrm{ns}}$ & $-0,01^{\mathrm{ns}}$ & $-0,03^{\text {ns }}$ & $0,01^{\mathrm{ns}}$ & $0,06^{\mathrm{ns}}$ & $0,05^{\text {ns }}$ \\
\hline P.B.M.S. & $0,01^{\text {ns }}$ & 00 & $0,23 * *$ & $-0,10^{\mathrm{ns}}$ & $-0,30 * *$ & & $-0,15^{*}$ & &, $19 * *$ & & $-0,16^{*}$ & \\
\hline a & $-0,10^{\text {ns }}$ & & 00 & $-0,8$ & $-0,60 * *$ & & -0 & & $* *$ & $-0,12^{\mathrm{ns}}$ & $1 * *$ & \\
\hline & & & $-0,86^{* *}$ & 1,00 & & & & & & & & \\
\hline Silte & . & & $-0,60 * *$ & $0,11^{\mathrm{ns}}$ & 1,00 & & & $-0,09^{\text {ns }}$ & & & & $0,37 * *$ \\
\hline pH C & $0,09^{\mathrm{ns}}$ & $-0,03^{\text {ns }}$ & $0,08^{\mathrm{ns}}$ & $-0,15^{*}$ & $0,08^{\mathrm{ns}}$ & 1,00 & $-0,74 * *$ & $-0,15^{*}$ & $0,02^{\mathrm{ns}}$ & $0,54 * *$ & $0,41 * *$ & $0,02^{\mathrm{ns}}$ \\
\hline $\mathbf{H}+\mathbf{A l}$ & $-0,02^{\text {ns }}$ & $-0,15^{*}$ & $-0,57 * *$ & $0,56^{* *}$ & $0,24 * *$ & $-0,74 * *$ & 1,00 & $0,09^{\mathrm{ns}}$ & $0,51 * *$ & $-0,22 * *$ & $0,04^{\mathrm{ns}}$ & $0,22 * *$ \\
\hline Al & & & & $0,03^{\mathrm{ns}}$ & $-0,09^{\mathrm{ns}}$ & & $0,09^{\mathrm{ns}}$ & 1,00 & $-0,01^{\mathrm{ns}}$ & $-0,05^{\mathrm{ns}}$ & $-0,11^{\text {ns }}$ & \\
\hline . & $-0,03^{\mathrm{ns}}$ & & & & $0,51 * *$ & & $0,51 * *$ & $-0,01^{\mathrm{ns}}$ & 1,00 & $0,13^{*}$ & & \\
\hline $\mathrm{Ca}$ & $0,01^{\mathrm{ns}}$ & $-0,12^{\text {ns }}$ & $-0,12^{\text {ns }}$ & $0,01^{\mathrm{ns}}$ & $0,21 * *$ & 0 , & $-0,2$ & $-0,05^{\text {ns }}$ & $0,13^{*}$ & 100 & $0,12^{\mathrm{ns}}$ & \\
\hline Mg & 0 & $-0,16^{*}$ & $-0,61 * *$ & $0,54 * *$ & $0,34 * *$ & 0, & 0 & $-0,11^{\text {ns }}$ & $0,50 * *$ & & 1,00 & $0,25^{* *}$ \\
\hline K & $-a_{0}$ & $-0,11^{\mathrm{ns}}$ & $-0,47 * *$ & $0,35 * *$ & $0,37 * *$ & $2^{\text {ns }}$ & $0,22 * *$ & ns & $0,38 * *$ & ${ }^{\text {ns }}$ & $0,25^{* *}$ & 1,00 \\
\hline $\mathbf{P}$ & 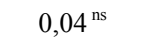 & $-0,06^{\text {ns }}$ & $0,12^{\mathrm{ns}}$ & $-0,14^{*}$ & $-0,02^{\mathrm{ns}}$ & $0,23 * *$ & $-0,22 * *$ & $-0,01^{\mathrm{ns}}$ & -0 , & $0,16^{*}$ & $2^{\mathrm{ns}}$ & $0,07^{\text {ns }}$ \\
\hline $\mathbf{S}$ & & & & 0 , & 0,2 & & & -0 & & & & \\
\hline SF & 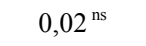 & 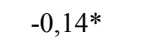 & $-0,22 * *$ & $0,11^{\mathrm{ns}}$ & $0,27 * *$ & & $-0,2$ & $-0,0$ & & $0,99 * *$ & & \\
\hline $\mathbf{m}^{\circ}$ & $-0,09^{\text {ns }}$ & $0,04^{\mathrm{ns}}$ & $0,09^{\mathrm{ns}}$ & $0,00^{\mathrm{ns}}$ & $-0,18^{*}$ & $-0,4$ & 0,3 & 0,8 & $-0,14^{\mathrm{ns}}$ & $-0,15^{*}$ & $-0,34 * *$ & $-0,03^{\mathrm{ns}}$ \\
\hline CTC & $1^{\mathrm{ns}}$ & $-0,18^{* *}$ & $-0,38 * *$ & $0,26 * *$ & $0,34 * *$ & $0,40 * *$ & $0,07^{\mathrm{ns}}$ & $-0,04^{\mathrm{ns}}$ & $0,36^{* *}$ & $0,94 * *$ & $0,30 * *$ & $0,18^{*}$ \\
\hline V\% & $0,09^{\mathrm{ns}}$ & $-0,06^{\mathrm{ns}}$ & $-0,14 *$ & $0,04^{\mathrm{ns}}$ & $0,21 * *$ & & $-0,60 * *$ & $-0,16^{*}$ & $0,19 * *$ & $0,51 * *$ & $0,65^{* *}$ & $0,11^{\mathrm{ns}}$ \\
\hline Mr & & $-0,10^{\mathrm{ns}}$ & $-0,59 * *$ & $0,49 * *$ & $0,38 * *$ & & $0,48 * *$ & $-0,0$ & & $0,01^{\mathrm{ns}}$ & & $0,25^{*}$ \\
\hline $\mathbf{F e}$ & $-0.07^{\text {ns }}$ & $-0,06^{\text {ns }}$ & $0,23 * *$ & $-0,29 * *$ & $-0,00^{\mathrm{ns}}$ & -0 , & $-0,05^{\text {ns }}$ & ns & -0 & $-0,16^{*}$ & $-0,25 * *$ & $-0,26^{*}$ \\
\hline $\mathrm{Cu}$ & $4^{\text {ns }}$ & $-0,18^{* *}$ & $-0,64 * *$ & $0,46^{* *}$ & $0,52 * *$ & $-0,11^{\mathrm{ns}}$ & $0,46^{* *}$ & $-0,02^{\text {ns }}$ & $0,49 * *$ & $0,02^{\mathrm{ns}}$ & $0,40 * *$ & $0,30 * *$ \\
\hline $\mathbf{Z n}$ & $-0,06^{\mathrm{ns}}$ & $0,03^{\mathrm{ns}}$ & $0,12^{\mathrm{ns}}$ & $-0,15^{*}$ & $0,01^{\mathrm{ns}}$ & $0,02^{\mathrm{ns}}$ & $-0,08^{\text {ns }}$ & $-0,04^{\text {ns }}$ & $-0,06^{\mathrm{ns}}$ & $-0,01^{\mathrm{ns}}$ & $-0,08^{\text {ns }}$ & $-0,10^{\mathrm{ns}}$ \\
\hline B & $-0,07^{\mathrm{ns}}$ & $-0,07^{\text {ns }}$ & $0,04^{\mathrm{ns}}$ & $-0,30 * *$ & $0,40 * *$ & & $-0,11^{\text {ns }}$ & $-0,14^{*}$ & $0,12^{\mathrm{ns}}$ & $0,12^{\mathrm{ns}}$ & $-0,12^{\text {ns }}$ & $0,07^{\mathrm{ns}}$ \\
\hline Altitude & $0,03^{\mathrm{ns}}$ & $0,22 * *$ & $0,72 * *$ & $-0,63 * *$ & $-0,42 * *$ & $0,23 * *$ & $-0,58^{* *}$ & $0,05^{\mathrm{ns}}$ & $-0,57^{* *}$ & $0,01^{\mathrm{ns}}$ & $-0,43^{* *}$ & $-0,41^{\prime}$ \\
\hline
\end{tabular}


Tabela 2. Matriz de coeficientes de correlação de Pearson entre as 24 variáveis em estudo $(n=170)$

\begin{tabular}{|c|c|c|c|c|c|c|c|c|c|c|c|c|}
\hline ari & $\mathbf{P}$ & $\mathbf{S}$ & SB & $\mathrm{m} \%$ & CTC & V\% & Mn & $\mathrm{Fe}$ & $\mathrm{Cu}$ & $\mathrm{Zn}$ & B & Altitude \\
\hline$\%$ E. & $0,04^{\mathrm{ns}}$ & $14 *$ & $2^{\mathrm{ns}}$ & & $01^{\mathrm{ns}}$ & $0,09^{\mathrm{ns}}$ & $00^{\mathrm{ns}}$ & $-0,07^{\mathrm{ns}}$ & $0,04^{\mathrm{ns}}$ & $-0,06^{\mathrm{ns}}$ & $-0,07^{\text {ns }}$ & $03^{\text {ns }}$ \\
\hline \%P.B.I & $-0,06^{\text {ns }}$ & $-0,13^{*}$ & $-0,14^{*}$ & $0,04^{\mathrm{ns}}$ & $-0,18^{* *}$ & $-0,06^{\text {ns }}$ & ns & $-0,06^{\mathrm{ns}}$ & $-0,18 * *$ & $0,03^{\text {ns }}$ & $-0,07^{\text {ns }}$ & $2 * *$ \\
\hline Areia & $0,12^{\mathrm{ns}}$ & $-0,51^{* *}$ & $-0,22 * *$ & $0,09^{\mathrm{ns}}$ & $-0,38^{* *}$ & $-0,14^{*}$ & $-0,59 * *$ & $0,23 * *$ & $-0,64 * *$ & & $0,04^{\mathrm{ns}}$ & $2 * *$ \\
\hline Argila & & $47 * *$ & & $0,00^{\mathrm{ns}}$ & $0,26^{* *}$ & $0,04^{\mathrm{ns}}$ & $49 * *$ & $-0,29 * *$ & $5 * *$ & $-0,15^{*}$ & $-0,30^{* *}$ & \\
\hline Silte & $-0,02$ & $0,26 * *$ & $0,27^{* *}$ & $-0,18^{*}$ & $0,34 * *$ & $0,21 * *$ & $0,38^{* *}$ & $-0,00^{\mathrm{ns}}$ & $0,52 * *$ & & $0,40^{* *}$ & $-0,42 * *$ \\
\hline pH & $0,23 * *$ & $-0,01^{\mathrm{ns}}$ & $0,59 * *$ & $-0,46^{* *}$ & $0,40 * *$ & $0,92 * *$ & $-0,11^{\mathrm{ns}}$ & $-0,11^{\mathrm{ns}}$ & $-0,11^{\mathrm{ns}}$ & $0,02^{\mathrm{ns}}$ & $0,12^{\mathrm{ns}}$ & $*$ \\
\hline $\mathbf{H}+\mathbf{A l}$ & $-0,22 * *$ & $0,28 * *$ & $-0,20 * *$ & $0,30 * *$ & $0,07^{\mathrm{ns}}$ & $-0,60 * *$ & $0,48 * *$ & $-0,05^{\mathrm{ns}}$ & $0,46^{* *}$ & $-0,08^{\mathrm{ns}}$ & $-0,11^{\text {ns }}$ & $-0,58 * *$ \\
\hline Al & $-0,01^{\text {ns }}$ & $-0,03^{\mathrm{ns}}$ & $-0,07^{\mathrm{ns}}$ & $0,88^{* *}$ & $-0,04^{\mathrm{ns}}$ & $-0,16^{*}$ & $-0,03^{\mathrm{ns}}$ & $0,02^{\mathrm{ns}}$ & -0 & -0 & $-0,14^{*}$ & ns \\
\hline M.O. & $-0,11^{\text {ns }}$ & $0,35 * *$ & $0,22 * *$ & $-0,14^{\mathrm{ns}}$ & $0,36^{* *}$ & $0,19^{* *}$ & $0,54 * *$ & $-0,15^{*}$ & $0,49^{* *}$ & $-0,06^{\mathrm{ns}}$ & & $-0,57^{* *}$ \\
\hline $\mathbf{C a}$ & & $0,07^{\mathrm{ns}}$ & $0,99 * *$ & $-0,15^{*}$ & $0,94 * *$ & $0,51 * *$ & $0,01^{\mathrm{ns}}$ & $-0,16^{*}$ & $0,02^{\mathrm{ns}}$ & $-0,01^{\mathrm{ns}}$ & $0,12^{\mathrm{ns}}$ & $0,01^{\mathrm{ns}}$ \\
\hline Mg & $0,02^{\mathrm{ns}}$ & $0,41^{* *}$ & $0,28^{* *}$ & $-0,34^{* *}$ & $0,30^{* *}$ & $0,65^{* *}$ & $0,41 * *$ & $-0,25^{* *}$ & $0,40 * *$ & $-0,08^{\mathrm{ns}}$ & $-0,12^{\mathrm{ns}}$ & $-0,43^{* *}$ \\
\hline K & $0,07^{\mathrm{ns}}$ & $0,32 * *$ & $0,11^{\mathrm{ns}}$ & $-0,03^{\mathrm{ns}}$ & $0,18^{*}$ & $0,11^{\mathrm{ns}}$ & $0,25^{* *}$ & $-0,26^{* *}$ & $0,30^{* *}$ & $-0,10^{\mathrm{ns}}$ & $0,07^{\mathrm{ns}}$ & $-0,41 * *$ \\
\hline $\mathbf{P}$ & 1,00 & $0,05^{\mathrm{ns}}$ & $0,15^{*}$ & $-0,07^{\mathrm{ns}}$ & $0,10^{\mathrm{ns}}$ & $0,21 * *$ & $-0,21^{* *}$ & $-0,02^{\mathrm{ns}}$ & $-0,19 * *$ & $0,23 * *$ & $0,05^{\mathrm{ns}}$ & $0,23 * *$ \\
\hline $\mathbf{S}$ & & & & & & & & $-0,2$ & & & & \\
\hline SB & $0,15^{*}$ & $0,14 *$ & 1,00 & $-0,20 * *$ & $0,96 * *$ & $0,60 * *$ & $0,08^{\mathrm{ns}}$ & $-0,20 * *$ & $0,09^{\mathrm{ns}}$ & $-0,03^{\mathrm{ns}}$ & $0,10^{\mathrm{ns}}$ & $-0,07^{\mathrm{ns}}$ \\
\hline $\mathbf{m} \%$ & $-0,07^{\mathrm{ns}}$ & $-0,05^{\mathrm{ns}}$ & $-0,20 * *$ & 1,00 & $-0,12^{\text {ns }}$ & $-0,51^{* *}$ & $-0,06^{\mathrm{ns}}$ & $0,08^{\mathrm{ns}}$ & $-0,05^{\text {ns }}$ & $-0,08^{\mathrm{ns}}$ & $-0,20^{* *}$ & $0,05^{\mathrm{ns}}$ \\
\hline CTC & $0,10^{\mathrm{ns}}$ & $0,22 * *$ & $0,96^{* *}$ & $-0,12^{\text {ns }}$ & 1,00 & $0,44 * *$ & $0,21 * *$ & $-0,21^{* *}$ & $0,21^{* *}$ & $-0,05^{\mathrm{ns}}$ & $0,07^{\mathrm{ns}}$ & $-0,23 * *$ \\
\hline V\% & $0,21 * *$ & $0,11^{\mathrm{ns}}$ & $0,60 * *$ & $-0,51^{* *}$ & $0,44 * *$ & 1,00 & $0,05^{\mathrm{ns}}$ & $-0,18^{* *}$ & $0,05^{\mathrm{ns}}$ & & & $0,03^{\mathrm{ns}}$ \\
\hline Mn & $-0,21 * *$ & $0,25 * *$ & $0,08^{\mathrm{ns}}$ & $-0,06^{\mathrm{ns}}$ & $0,21 * *$ & $0,05^{\text {ns }}$ & 1,00 & $-0,19 * *$ & $0,84 * *$ & $-0,02^{\mathrm{ns}}$ & $-0,07^{\text {ns }}$ & $-0,63 * *$ \\
\hline $\mathrm{Fe}$ & $-0,02^{\mathrm{ns}}$ & $-0,20 * *$ & $-0,20 * *$ & $0,08^{\mathrm{ns}}$ & $-0,21^{* *}$ & $-0,18^{* *}$ & $-0,19 * *$ & 1,00 & $-0,13^{*}$ & $-0,00^{\mathrm{ns}}$ & $0,28 * *$ & $0,25 * *$ \\
\hline $\mathrm{Cu}$ & $-0,19^{* *}$ & $0,30 * *$ & $0,09^{\mathrm{ns}}$ & $-0,05^{\mathrm{ns}}$ & $0,21 * *$ & $0,05^{\mathrm{ns}}$ & $0,84 * *$ & $-0,13^{*}$ & 1,00 & $0,01^{\mathrm{ns}}$ & $-0,03^{\text {ns }}$ & $-0,55^{* *}$ \\
\hline $\mathbf{Z n}$ & $0,23 * *$ & $-0,10^{\mathrm{ns}}$ & $-0,03^{\mathrm{ns}}$ & $-0,08^{\text {ns }}$ & $-0,05^{\text {ns }}$ & $0,02^{\mathrm{ns}}$ & $-0,02^{\mathrm{ns}}$ & $-0,00^{\mathrm{ns}}$ & $0,01^{\mathrm{ns}}$ & 1,00 & $0,10^{\mathrm{ns}}$ & $0,10^{\mathrm{ns}}$ \\
\hline B & $0,05^{\mathrm{ns}}$ & $-0,04^{\mathrm{ns}}$ & $0,10^{\mathrm{ns}}$ & $-0,20 * *$ & $0,07^{\mathrm{ns}}$ & $0,10^{\mathrm{ns}}$ & $-0,07^{\mathrm{ns}}$ & $0,28 * *$ & $-0,03^{\text {ns }}$ & $0,10^{\mathrm{ns}}$ & 1,00 & $0,08^{\mathrm{ns}}$ \\
\hline Altitude & $0,23 * *$ & $-0,38^{* *}$ & $-0,07^{\mathrm{ns}}$ & $0,05^{\mathrm{ns}}$ & $-0,23^{* *}$ & $0,03^{\mathrm{ns}}$ & $-0,63 * *$ & $0,25 * *$ & $-0,55 * *$ & $0,10^{\mathrm{ns}}$ & $0,08^{\mathrm{ns}}$ & 1,00 \\
\hline
\end{tabular}

$* *$ e $*$ significativo a $1 \%$ e $5 \%$ de probabilidade pelo teste $\mathrm{t}$, respectivamente.

ns - não significativo.

Onde: (\%E.E.M.S.) Porcentagem de Extrato Etéreo na Matéria Seca, (\%P.B.M.S.) Porcentagem de Proteína Bruta na Matéria Seca, $(\mathrm{m} \%)$ Porcentagem de Saturação por Alumínio e (V\%) Porcentagem de Saturação por Bases $=\%$; Areia, Argila e Silte $=\mathrm{g}^{\mathrm{kg}}{ }^{-1} ;(\mathrm{H}+\mathrm{Al})$ Acidez Potencial, (Al) Alumínio, (Ca) Cálcio, (Mg) Magnésio, (K) Potássio, (SB) Soma de Bases e (CTC) Capacidade de Troca de Cátions $=$ mmolc.dm ${ }^{-3}$; (M.O.) Matéria Orgânica $=$ g.dm ${ }^{-3}$; $(\mathrm{P})$ Fósforo, (S) Enxofre, (Mn) Manganês, (Fe) Ferro, (Cu) Cobre, ( $\mathrm{Zn})$ Zinco e (B) Boro = $\mathrm{mg} \cdot \mathrm{dm}^{-3} ;$ Altitude $=\mathrm{m}$.

O coeficiente de correlação varia de -1 a +1 : -1 significa que há uma relação perfeitamente negativa entre as duas variáveis; +1 significa que há uma relação perfeitamente positiva entre as duas variáveis e 0 (zero) significa a inexistência de correlação. De acordo com Schmidt (1975), o coeficiente de correlação pode ser classificado, considerando seu valor numérico, em cinco categorias: desprezível $(0,00$ a $0,29)$; baixo $(0,30$ a 0,49$)$; moderado $(0,50$ a 0,79$)$; alto $(0,80$ a 0,99$)$ e perfeito $(1,00)$. Basicamente, todo e qualquer coeficiente de correlação superior a $80 \%(0,80)$ revela que 
a reta é representativa dos pontos levantados (Vanni, 1998).

No presente trabalho consideraram-se, portanto, os valores de coeficiente de correlação $\geq 0,50$ para discussão dos resultados. Dessa forma, fazendo-se uma análise da matriz de correlação, pode-se observar que:

No presente estudo como é observado na Tabela 2, não houve correlação satisfatória entre os níveis de fertilidade e textura do solo e altitude com os teores de óleo (\%E.E.M.S.) e proteína (\%P.B.M.S.). Todas as correlações encontradas foram classificadas como desprezíveis a baixas. Esse resultado mostra que outros fatores interferiram nos teores de óleo (\%E.E.M.S.) e proteína (\%P.B.M.S.) mapeados com uma influência maior do que o nível de fertilidade do solo e textura do solo e altitude. Esses resultados foram contrários a nossa expectativa de obter uma alta correlação com a matéria orgânica, uma vez que se pode calcular o teor de nitrogênio total com base no teor de matéria orgânica. Entretanto, o teor de nitrogênio total não tem valor agronômico para a previsão da disponibilidade desse nutriente para as culturas (Tomé Júnior, 1997).

Analisando a variável areia, observa-se um coeficiente de correlação moderado com as variáveis: silte $\left(-0,60^{* *}\right)$, acidez potencial $(-0,57 * *)$, matéria orgânica $(-0,72 * *)$, magnésio $\left(-0,61^{* *}\right)$, enxofre $\left(-0,51^{* *}\right)$, manganês $\left(-0,59^{* *}\right)$, cobre $\left(-0,64^{* *}\right)$ e altitude $\left(0,72^{* *}\right)$. E uma alta correlação com a argila $\left(-0,86^{* *}\right)$, o que era de se esperar, pois onde se encontram teores altos de areia, encontram-se teores baixos de argila.

Além das correlações mencionadas acima, as correlações da variável argila são moderadas com as variáveis: acidez potencial $\left(0,56^{* *}\right)$, matéria orgânica $\left(0,57^{* *}\right)$, magnésio $(0,54 * *)$ e altitude $\left(-0,63^{* *}\right)$.

A variável silte possui uma moderada correlação com as variáveis matéria orgânica $\left(0,51^{* *}\right)$, cobre $\left(0,52^{* *}\right)$ e com a areia mencionado anteriormente.

Sendo $\mathrm{SB}=\mathrm{Ca}+\mathrm{Mg}+\mathrm{K} ; \mathrm{CTC}=\mathrm{SB}+(\mathrm{H}+\mathrm{Al}) ; \mathrm{V} \%=\frac{100 . S B}{C T C} \mathrm{e}$ $\mathrm{m} \%=\frac{100 . A l}{(S B+A l)}$, é esperado o fato de as variáveis $\mathrm{SB}, \mathrm{CTC}, \mathrm{V} \% \mathrm{e} \mathrm{m} \%$ se relacionarem com suas variáveis de formação e também uma correlação entre $\mathrm{pH} \mathrm{CaCl}_{2}$ e acidez potencial. 
A variável $\mathrm{pH} \mathrm{CaCl} \mathrm{Cl}_{2}$ possui uma moderada correlação com as variáveis acidez potencial $\left(-0,74^{* *}\right)$, cálcio $\left(0,54^{* *}\right)$ e soma de bases $(0,59 * *)$. Verifica-se que a correlação moderada negativa para acidez potencial $\left(-0,74^{* *}\right)$, é esperada porque onde se tem $\mathrm{pH} \mathrm{CaCl} 2$ alto, se tem uma acidez potencial baixa, podendo-se determinar um gráfico que melhor representa os solos da região (Tomé Júnior, 1997). Tendo uma alta correlação com a variável porcentagem de saturação por bases $\left(0,92^{* *}\right)$, concordando com Souza et al. (1989), quanto maior o $\mathrm{pH} \mathrm{CaCl}_{2}$, mais elevada será a porcentagem de saturação por bases; embora não seja seguro se tentar prever o valor exato da porcentagem de saturação por bases, é possível estabelecer uma linha de tendência média entre o $\mathrm{pH} \mathrm{CaCl} 2$ e porcentagem de saturação por bases, mas os valores de cada solo podem se afastar dessa média. Além disso, de uma região para outra pode haver considerável diferença (Tomé Júnior, 1997).

Além das correlações já citadas anteriormente, a variável acidez potencial possui uma correlação moderada com as variáveis: matéria orgânica $\left(0,51^{* *}\right)$, porcentagem de saturação por bases $\left(-0,60^{* *}\right)$ e altitude $\left(-0,58^{* *}\right)$.

A variável alumínio possui uma alta correlação com a variável porcentagem de saturação por alumínio $\left(0,88^{* *}\right)$, devido a variável alumínio participar do cálculo da variável porcentagem de saturação por alumínio.

Além das variáveis já citadas anteriormente, a variável matéria orgânica possui uma moderada correlação com as variáveis: magnésio $\left(0,50^{* *}\right)$, manganês $\left(0,54^{* *}\right)$ e altitude $\left(-0,57^{* *}\right)$.

A variável cálcio possui uma moderada correlação com as variáveis porcentagem de saturação por bases $\left(0,51^{* *}\right)$ e com $\mathrm{pH} \mathrm{CaCl}_{2}$ citado anteriormente. $\mathrm{O}$ cálcio tem uma alta correlação com as variáveis soma de bases $\left(0,99^{* *}\right)$ e capacidade de troca de cátions $\left(0,94^{* *}\right)$. Tomé Júnior (1997) considera que os teores de cálcio e magnésio estão estreitamente relacionados com o nível de acidez do solo e com as variáveis nas quais o cálcio é utilizado no cálculo como a soma de bases, capacidade de troca de cátions e porcentagem de saturação por bases. Portanto neste trabalho pode-se observar que a variável magnésio tem uma moderada correlação com a variável porcentagem de saturação por bases $\left(0,65^{* *}\right)$, além das variáveis já citadas 
anteriormente.

Ainda sobre as correlações de cálcio e magnésio, podem ocorrer casos, entretanto, em que o solo apresenta baixos teores de cálcio e magnésio, mas também baixa capacidade de troca de cátions (o que é comum em solos arenosos). Sendo a porcentagem de saturação por bases um valor relativo, pode se apresentar elevada nessas condições, dando uma falsa indicação de fertilidade elevada. Daí a importância de se classificarem também os valores de cálcio e magnésio (Tomé Júnior, 1997).

As correlações das variáveis potássio e fósforo estão classificadas nos níveis desprezível e baixo com relação às outras variáveis e entre si.

A variável soma de bases possui uma moderada correlação com as variáveis porcentagem de saturação por bases $\left(0,60^{* *}\right)$ e $\mathrm{pH} \mathrm{CaCl}_{2}$, conforme citado anteriormente. E uma alta correlação com as variáveis capacidade de troca de cátions $\left(0,96^{* *}\right)$ e cálcio também citado. Era de se esperar uma alta correlação entre capacidade de troca de cátions e soma de bases, uma vez que essa participa do cálculo da variável capacidade de troca de cátions.

A variável porcentagem de saturação por alumínio possui uma alta correlação com a variável alumínio $\left(0,88^{* *}\right)$, já comentado, e uma moderada correlação com a variável porcentagem de saturação por bases $\left(-0,51^{* *}\right)$.

Com relação aos micronutrientes, o manganês além das correlações citadas tem uma moderada correlação com a altitude $\left(-0,63^{* *}\right)$ e uma alta correlação com o cobre $\left(0,84^{* *}\right)$; o ferro possui apenas correlações desprezíveis; o cobre além das correlações citadas tem uma moderada correlação com a altitude $\left(-0,55^{* *}\right)$; as correlações das variáveis zinco e boro estão classificadas abaixo do nível moderado.

A Tabela 3 contém as informações das variáveis utilizadas para a verificação da posição e dispersão: 
Tabela 3. Resultados da análise estatística descritiva realizada para as variáveis do mapeamento dos atributos da soja e do solo com os dados discrepantes ("outliers")

\begin{tabular}{|c|c|c|c|c|c|c|c|c|}
\hline Variáveis & Médias & Variâncias & $\begin{array}{l}\text { Desvios } \\
\text { Padrão }\end{array}$ & $\begin{array}{c}\text { Valores } \\
\text { Mínimos }\end{array}$ & Quartis 1 & Medianas & Quartis 3 & $\begin{array}{l}\text { Valores } \\
\text { Máximos }\end{array}$ \\
\hline \%E.E.M.S. & 19,19 & 6,55 & 2,56 & 12,40 & 17,40 & 19,45 & 20,93 & 26,70 \\
\hline \%P.B.M.S. & 40,60 & 10,58 & 3,25 & 31,12 & 39,54 & 41,50 & 42,72 & 47,68 \\
\hline Areia & 778,60 & 6059,06 & 77,84 & 501,80 & 752,78 & 814,60 & 830,78 & 862,00 \\
\hline Argila & 161,65 & 3896,13 & 62,42 & 12,00 & 127,75 & 151,85 & 179,00 & 365,00 \\
\hline Silte & 59,75 & 1597,60 & 39,97 & 1,70 & 28,18 & 48,90 & 82,13 & 243,20 \\
\hline $\mathrm{pH} \mathrm{CaCl}{ }_{2}$ & 4,79 & 0,19 & 0,44 & 4,00 & 4,50 & 4,70 & 5,00 & 7,20 \\
\hline $\mathrm{H}+\mathrm{Al}$ & 28,42 & 49,74 & 7,05 & 10,00 & 24,00 & 28,00 & 33,00 & 50,00 \\
\hline $\mathrm{Al}$ & 1,41 & 24,15 & 4,91 & 0,00 & 0,00 & 1,00 & 1,25 & 64,00 \\
\hline M.O. & 18,47 & 5,47 & 2,34 & 14,00 & 17,00 & 18,00 & 20,00 & 26,00 \\
\hline $\mathrm{Ca}$ & 17,51 & 649,23 & 25,48 & 6,00 & 12,00 & 15,00 & 18,25 & 340,00 \\
\hline $\mathrm{Mg}$ & 9,12 & 18,27 & 4,27 & 4,00 & 6,00 & 8,00 & 11,00 & 32,00 \\
\hline $\mathrm{K}$ & 1,18 & 0,37 & 0,60 & 0,40 & 0,80 & 1,10 & 1,40 & 5,50 \\
\hline $\mathrm{P}$ & 9,38 & 43,02 & 6,56 & 3,00 & 5,00 & 7,00 & 11,00 & 48,00 \\
\hline $\mathrm{S}$ & 7,85 & 68,81 & 8,30 & 0,90 & 3,90 & 5,50 & 8,05 & 61,30 \\
\hline SB & 27,87 & 695,94 & 26,38 & 11,00 & 19,00 & 24,00 & 31,00 & 346,00 \\
\hline $\mathrm{m} \%$ & 5,05 & 49,24 & 7,02 & 0,00 & 0,00 & 4,00 & 7,00 & 77,00 \\
\hline CTC & 56,22 & 670,29 & 25,89 & 39,00 & 46,00 & 50,00 & 60,75 & 356,00 \\
\hline V\% & 47,16 & 124,17 & 11,14 & 24,00 & 40,00 & 46,00 & 54,00 & 97,00 \\
\hline $\mathrm{Mn}$ & 23,92 & 576,96 & 24,02 & 1,20 & 7,07 & 12,10 & 36,25 & 101,90 \\
\hline $\mathrm{Fe}$ & 21,38 & 72,08 & 8,49 & 1,80 & 16,98 & 19,75 & 23,53 & 75,90 \\
\hline $\mathrm{Cu}$ & 1,89 & 2,83 & 1,68 & 0,50 & 0,80 & 1,05 & 2,63 & 8,90 \\
\hline $\mathrm{Zn}$ & 0,68 & 0,19 & 0,44 & 0,20 & 0,40 & 0,60 & 0,80 & 3,30 \\
\hline B & 0,23 & 0,01 & 0,08 & 0,12 & 0,14 & 0,23 & 0,29 & 0,42 \\
\hline
\end{tabular}

Unidades: \%E.E.M.S., \%P.B.M.S., $\mathrm{m} \%$ e V\% $=\%$; Areia, Argila e Silte $=$ g.kg $^{-1} ; \mathrm{H}+\mathrm{Al}, \mathrm{Al}, \mathrm{Ca}, \mathrm{Mg}, \mathrm{K}$, $\mathrm{SB}$ e CTC $=$ mmolc.dm ${ }^{-3}$; M.O. $=$ g.dm ${ }^{-3} ; \mathrm{P}, \mathrm{S}, \mathrm{Mn}, \mathrm{Fe}, \mathrm{Cu}, \mathrm{Zn}$ e B $=$ mg.dm ${ }^{-3}$.

A média das variáveis em estudo representadas na Tabela 3 é discutida a seguir:

A média dos valores das variáveis óleo (\%E.E.M.S.) e proteína (\%P.B.M.S.) está entre os intervalos $(16,1$ a 22,4) e $(36,6$ a 45,5), respectivamente, citados por Carvalho \& Nakagawa (2000), adaptado de Hymowitz et al. (1972), e bem próximo da média obtida de 18,8 e 42,0, respectivamente, para o grupo de maturação do cultivar utilizado para este trabalho.

Fazendo-se a classificação textural do solo, com relação aos teores médios de areia, argila e silte, mencionados na Tabela 3, pode-se dizer que o solo em questão está classificado como de textura média (Prado, 1993).

Com relação ao $\mathrm{pH} \mathrm{CaCl}_{2}$, o valor está classificado como alto e quanto á acidez 
potencial $(\mathrm{H}+\mathrm{Al})$ não há classificação, pois o objetivo principal dessa determinação é o cálculo da capacidade de troca de cátions (CTC). Genericamente, pode-se dizer que há uma tendência de ocorrer maiores teores de acidez potencial $(\mathrm{H}+\mathrm{Al})$ em solos ricos em matéria orgânica (M.O.), principalmente se eles apresentarem $\mathrm{pH}$ muito baixo (Tomé Júnior, 1997).

O alumínio (Al) está classificado como baixo; por outro lado, apenas o teor de alumínio (Al) nem sempre é suficiente para caracterizar sua toxidez para as plantas, pois ela depende também da proporção que o alumínio (Al) ocupa na capacidade de troca de cátions (CTC). Portanto, para se avaliar corretamente a toxidez por alumínio (Al) devese calcular também a porcentagem de saturação por alumínio $(\mathrm{m} \%)$.

Pode-se notar na Tabela 3 que os valores médios para as variáveis calculadas estão classificados como: o valor obtido para porcentagem de saturação por bases (V\%) é classificado como baixo; portanto, como é menor que 50\%, é classificado como distrófico, considerado um solo pouco fértil, havendo a necessidade de elevá-lo a $60 \%$ para a cultura da soja (Raij et al., 1996). O valor médio da porcentagem por alumínio $(\mathrm{m} \%)$ está classificado como baixo, sendo, portanto, não-prejudicial à maioria das culturas, devendo-se ressaltar que esses são índices genéricos, havendo considerável diferença entre culturas e/ou cultivares na tolerância à toxidez por alumínio (Al) (Malavolta, 1992). E para os valores capacidade de troca de cátions (CTC) e soma de bases (SB), não há classificação para eles.

O teor de matéria orgânica (M.O.) é classificado como médio, sendo esse o resultado do balanço entre processos de adição de matéria orgânica (restos de plantas, etc.) e perda (decomposição desses materiais pelos microorganismos). Nas condições de clima tropical e subtropical (temperaturas elevadas e umidade abundante), como na maior parte do Brasil, é grande a produção de biomassa (elevada adição), mas a velocidade de mineralização da matéria orgânica também é elevada. Somando-se a isso o incremento da mineralização causado pelo preparo anual do solo agricultado tem-se, como conseqüência, que dificilmente um solo utilizado para agricultura apresentará teores elevados de matéria orgânica (após alguns anos de cultivo esse teor se estabiliza em torno de 25 a $30 \mathrm{~g} \cdot \mathrm{dm}^{-3}$ em solos argilosos e valores mais baixos em solos de textura 
média ou arenosa), (Tomé Júnior, 1997). Raij et al. (1996) consideram o teor de matéria orgânica (M.O.) ser útil para dar idéia da textura do solo, com valores até de $15 \mathrm{~g} . \mathrm{dm}^{-3}$ para solos arenosos, entre 16 e $30 \mathrm{~g} \cdot \mathrm{dm}^{-3}$ para solos de textura média e de 31 a $60 \mathrm{~g} . \mathrm{dm}^{-3}$ para solos argilosos. Valores muito acima de $60 \mathrm{~g} \cdot \mathrm{dm}^{-3}$ indicam acúmulo de matéria orgânica (M.O.) no solo por condições localizadas, em geral por má drenagem ou acidez elevada. O teor de matéria orgânica (M.O.) do solo não revelou ser, no estado de São Paulo, um índice adequado para predizer a disponibilidade de nitrogênio $(\mathrm{N})$ em solos e, conseqüentemente, não tem sido usado para essa finalidade.

Os teores de cálcio $(\mathrm{Ca})$ e magnésio $(\mathrm{Mg})$ estão classificados como alto (Raij et al., 1996), e estão estreitamente relacionados com o nível de acidez do solo, como mencionado anteriormente (Tomé Júnior, 1997).

Os teores de fósforo $(\mathrm{P})$ e potássio $(\mathrm{K})$ estão classificados como baixos (Raij et al., 1996). A adubação da cultura em estudo seguiu a tabela sugerida por Raij et al. (1996), para uma produtividade esperada entre 2,5 a 2,9t.ha ${ }^{-1}$.

O teor de enxofre $(\mathrm{S})$ está classificado como médio, semelhante ao nitrogênio $(\mathrm{N})$, o enxofre (S) tem uma dinâmica complexa no solo, mas na forma iônica de sulfato $\left(\mathrm{SO}_{4}{ }^{2-}\right)$ é mais adsorvido pelos colóides do solo que o nitrato $\left(\mathrm{NO}_{3}{ }^{-}\right)$, sendo trocável por outros ânions, como o fosfato $\left(\mathrm{H}_{2} \mathrm{PO}_{4}{ }^{-}\right)$. Assim, a amostragem do solo para análise de sulfato deve também ser feita na camada de 0,2 a $0,4 \mathrm{~m}$, quando a profundidade do sistema radicular assim o justificar (Raij et al., 1996).

Com relação aos teores de micronutrientes, os teores de manganês (Mn), ferro $(\mathrm{Fe})$, e cobre $(\mathrm{Cu})$ estão classificados como alto e os teores de zinco $(\mathrm{Zn})$ e boro $(\mathrm{B})$ são classificados como médio (Raij et al., 1996).

Como somente a variável boro (B) não apresentou dados discrepantes (“outliers"), foram analisadas novamente todas elas no que diz respeito à estatística descritiva, mas excluindo-se os dados discrepantes (“outliers"). Assim, segue-se a Tabela 4 com as análises obtidas. 
Tabela 4. Resultado da análise estatística descritiva realizada para as variáveis do mapeamento dos atributos da soja e do solo sem os dados discrepantes (“outliers")

\begin{tabular}{|c|c|c|c|c|c|c|c|c|c|c|}
\hline Variáveis & $\mathrm{n}$ & Médias & Quar & Medianas & Quartis 3 & Vari & $\begin{array}{l}\text { Desvios } \\
\text { Padrão } \\
\end{array}$ & Ass & oses & $\begin{array}{l}\text { CV } \\
(\%) \\
\end{array}$ \\
\hline oE.E.M.S. & 167 & 19,06 & 17,40 & 19,40 & 20,80 & 5,69 & 2,38 & $-0,45$ & $-0,17$ & 12,5 \\
\hline oP.B.M.S. & 153 & 41,38 & 39,85 & 41,68 & 42,77 & 4,15 & 2,04 & $-0,44$ & 0,23 & 4,9 \\
\hline Areia & 156 & 795,22 & 781,48 & 817,85 & 831,55 & 3086,89 & 55,56 & & & 7,0 \\
\hline Argila & 147 & 149,01 & 127,00 & 149,00 & 166,00 & 1600 & 40,01 & & & 26,9 \\
\hline Silte & 168 & 57,87 & 27,93 & 47,30 & 80,58 & 1306,51 & 36,15 & & $-0,36$ & 62,5 \\
\hline $\mathrm{pH} \mathrm{CaCl}{ }_{2}$ & 165 & 4,74 & 4,50 & 4,70 & 5,00 & 0,12 & 0,35 & 0,52 & $-0,05$ & 7,4 \\
\hline $\mathrm{H}+\mathrm{Al}$ & 165 & 28,03 & 24,00 & 28,00 & 32,00 & 38,69 & 6,22 & 0,44 & 0,08 & 22,2 \\
\hline $\mathrm{Al}$ & 167 & 0,99 & 0,00 & 1,00 & 1,00 & 0,69 & 0,83 & 0,58 & $-0,14$ & 83,8 \\
\hline M.O. & 169 & 18,42 & 17,00 & 18,00 & 20,00 & 5,16 & 2,27 & 0,66 & $-0,22$ & 12,3 \\
\hline $\mathrm{Ca}$ & 163 & 15,02 & 12,00 & 14,00 & 18,00 & 21,50 & 4,64 & 0,59 & $-0,10$ & 30,9 \\
\hline $\mathrm{Mg}$ & 164 & 8,59 & & 8,00 & 10,00 & 10,12 & 3,18 & 0,89 & 0,11 & 37,0 \\
\hline $\mathrm{K}$ & 162 & 1, & & & & & 0 & 0,34 & $-0,38$ & 33,9 \\
\hline 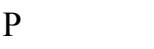 & 160 & & & & 10,00 & 16 , & 4, & & & 50,1 \\
\hline $\mathrm{s}$ & 155 & 5,78 & 3 & 5,10 & 7,50 & 6 & 2 , & 0,99 & 0,59 & 42,6 \\
\hline SB & 164 & 25,01 & 19,00 & 23,00 & 30,00 & 62,98 & 7,94 & 0,77 & 0,03 & 31,7 \\
\hline $\mathrm{m} \%$ & 168 & 4,51 & 0,00 & 4,00 & 7,00 & 16,61 & 4,08 & 0,73 & $-0,04$ & 90,5 \\
\hline CTC & 167 & 53,96 & 46,00 & 50,00 & 58,00 & 118,01 & 10,86 & 1,04 & 0,06 & 20,1 \\
\hline V\% & 167 & 46,47 & 40,00 & 46,00 & 54,00 & 97,97 & 9,90 & 0,18 & $-0,42$ & 21,3 \\
\hline $\mathrm{Mn}$ & 163 & 20,97 & 6,90 & 11,40 & 29,10 & 387,34 & 19,68 & 1,25 & 0,36 & 93,8 \\
\hline $\mathrm{Fe}$ & 158 & 19,93 & 16 , & 19,10 & 22,73 & 28,39 & 5,33 & 0,45 & 0,22 & 26,7 \\
\hline $\mathrm{Cu}$ & 160 & & & & & & 1,22 & & 0,77 & 76,3 \\
\hline $\mathrm{Zn}$ & 166 & 0,63 & 0,40 & 0,60 & 0,80 & 0,07 & 0,27 & 0,80 & 0,18 & 42,9 \\
\hline B & 170 & 0,23 & 0,14 & 0,23 & 0,29 & 0,01 & 0,08 & 0,19 & $-1,12$ & 34,8 \\
\hline
\end{tabular}

Onde: $\mathrm{n}=$ Número de amostras e $\mathrm{CV}=$ Coeficientes de variação.

Pode-se notar na Tabela 4 que foram incluídas as informações de assimetria e curtose para cada variável. Isso foi feito para facilitar a identificação quanto à normalidade dos dados. Além dessas informações, foram construídos também os gráficos de estatística descritiva, onde se pode analisar a normalidade dos dados, juntamente com sua possível distribuição.

De acordo com Vanni (1998), um coeficiente de variação (CV) maior que 35\% revela que a série é heterogênea e a média tem pouco significado. Se for maior que $65 \%$, revela que a série é muito heterogênea e a média não tem significado algum. Porém, se for menor que $35 \%$, revela que a série é homogênea e a média tem grande significado, podendo ser utilizada como representativa da série de onde foi obtida. Dessa forma 
pode-se dizer que as variáveis \%E.E.M.S., P.B.M.S., areia, argila, $\mathrm{pH} \mathrm{CaCl}_{2}, \mathrm{H}+\mathrm{Al}$, M.O., Ca, K, SB, CTC, V\%, Fe e B são homogêneas e a média tem grande significado, enquanto as variáveis silte, $\mathrm{Mg}, \mathrm{P}, \mathrm{S}$ e $\mathrm{Zn}$ são heterogêneas e a média tem pouco significado e as variáveis $\mathrm{Al}, \mathrm{m} \%, \mathrm{Mn}$ e $\mathrm{Cu}$ são muito heterogêneas e a média não tem significado algum.

A variabilidade das características químicas e físicas dos solos é um atributo particularizado, que é modificado pelo manejo. Vários autores (Oliveira, 1972; Barreto et al., 1974; Chitolina, 1982; Saraiva, 1989) mostram que os componentes de variância expressos na forma de coeficientes de variação correspondem a aproximadamente $10 \%$ em propriedade pouco influenciada pelo manejo, como a areia, de $25 \%$ em matéria orgânica, capacidade de troca de cátions, e de 35\% a $50 \%$ em fatores de $\mathrm{P}$ e $\mathrm{K}$ disponíveis e $\mathrm{Ca}$ e $\mathrm{Mg}$ trocáveis, que são muito mais afetados pelo manejo. Alguns coeficientes de variação podem chegar a superar os $100 \%$, principalmente de $\mathrm{P}$ e K disponíveis, em solos que já haviam sido adubados. Já o $\mathrm{pH} \mathrm{CaCl}_{2}$ e matéria orgânica são características de menor variabilidade; Oliveira (1972) diz que um coeficiente de variação de $10 \%$ para o $\mathrm{pH} \mathrm{CaCl}_{2}$ apesar de relativamente pouco elevado indicaria a ocorrência de valores suficientemente afastados para sugerir a existência de solos com reações completamente diferentes do ponto de vista agrícola e que um coeficiente de variação desta ordem não pode ser considerado, em pedologia, como baixo.

Conforme discutido na Seção 3.7.1, a Tabela 5 mostra os intervalos de valores para cada variável que representa a configuração de uma distribuição normal, para isso os valores de assimetria, curtose e a relação entre a amplitude total dos dados sobre desvio padrão (A/s) devem estar dentro dos limites de intervalos associados para cada variável.

Tabela 5. Intervalos de valores para uma distribuição normal (Preston, 1970)

\begin{tabular}{lccccccccc}
\hline Variáveis & $\mathbf{n}$ & $\begin{array}{c}\text { Valores } \\
\text { Mínimos }\end{array}$ & $\begin{array}{c}\text { Valores } \\
\text { Máximos }\end{array}$ & Assimetrias & Curtoses & A/s & $\begin{array}{c}* \text { Limites } \\
\text { para } \\
\text { Assimetrias }\end{array}$ & $\begin{array}{c}* \text { Limites } \\
\text { para } \\
\text { Curtoses }\end{array}$ & $\begin{array}{c}\text { *Limites } \\
\text { para } \\
\text { A/s }\end{array}$ \\
\hline \%E.E.M.S. & 167 & 12,40 & 24,40 & $-0,45$ & $-0,17$ & 5,04 & $-0,30$ a 0,30 & 2,48 a 3,62 & 4,67 a 6,27 \\
\%P.B.M.S. & 153 & 35,79 & 46,78 & $-0,44$ & 0,23 & 5,39 & $-0,32$ a 0,32 & 2,45 a 3,66 & 4,60 a 6,20 \\
Areia & 156 & 636,60 & 862,00 & $-1,45$ & 1,04 & 4,07 & $-0,31$ a 0,31 & 2,47 a 3,64 & 4,63 a 6,23 \\
Argila & 147 & 66,00 & 255,00 & 0,40 & 0,41 & 4,72 & $-0,32$ a 0,32 & 2,45 a 3,66 & 4,63 a 6,23
\end{tabular}


Tabela 5. Intervalos de valores para uma distribuição normal (Preston, 1970)

\begin{tabular}{|c|c|c|c|c|c|c|c|c|c|}
\hline Variáveis & $\mathbf{n}$ & $\begin{array}{l}\text { Valores } \\
\text { Mínimos }\end{array}$ & $\begin{array}{l}\text { Valores } \\
\text { Máximos }\end{array}$ & Assimetrias & Curtoses & $\mathbf{A} / \mathbf{s}$ & $\begin{array}{c}\text { *Limites } \\
\text { para } \\
\text { Assimetrias }\end{array}$ & $\begin{array}{c}{ }^{*} \text { Limites } \\
\text { para } \\
\text { Curtoses }\end{array}$ & $\begin{array}{c}* \text { Limites } \\
\text { para } \\
\text { A/s }\end{array}$ \\
\hline Silte & 168 & 1,70 & 155,60 & 0,73 & $-0,36$ & 4,26 & $-0,30$ a 0,30 & 2,48 a 3,62 & 4,67 a 6,27 \\
\hline $\mathrm{pH} \mathrm{CaCl} 2$ & 165 & 4,0 & 5,7 & 0,52 & $-0,05$ & 4,86 & $-0,30$ a 0,30 & 2,48 a 3,62 & 4,67 a 6,27 \\
\hline $\mathrm{H}+\mathrm{Al}$ & 165 & 13 & 45 & 0,44 & 0,08 & 5,14 & $-0,30$ a 0,30 & 2,48 a 3,62 & 4,67 a 6,27 \\
\hline $\mathrm{Al}$ & 167 & 0 & 3 & 0,58 & $-0,14$ & 3,61 & $-0,30$ a 0,30 & 2,48 a 3,62 & 4,67 a 6,27 \\
\hline M.O. & 169 & 14 & 24 & 0,66 & $-0,22$ & 4,41 & $-0,30$ a 0,30 & 2,48 a 3,62 & 4,67 a 6,27 \\
\hline $\mathrm{Ca}$ & 163 & 6 & 27 & 0,59 & $-0,10$ & 4,53 & $-0,31$ a 0,31 & 2,47 a 3,64 & 4,63 a 6,23 \\
\hline $\mathrm{Mg}$ & 164 & 4 & 18 & 0,89 & 0,11 & 4,40 & $-0,31$ a 0,31 & 2,47 a 3,64 & 4,63 a 6,23 \\
\hline $\mathrm{K}$ & 162 & 0,4 & 2,1 & 0,34 & $-0,38$ & 4,59 & $-0,31$ a 0,31 & 2,47 a 3,64 & 4,63 a 6,23 \\
\hline $\mathrm{P}$ & 160 & 3 & 20 & 1,18 & 0,82 & 4,17 & $-0,31$ a 0,31 & 2,47 a 3,64 & 4,63 a 6,23 \\
\hline $\mathrm{S}$ & 155 & 0,9 & 13,5 & 0,99 & 0,59 & 5,12 & $-0,31$ a 0,31 & 2,47 a 3,64 & 4,63 a 6,23 \\
\hline SB & 164 & 11 & 46 & 0,77 & 0,03 & 4,41 & $-0,31$ a 0,31 & 2,47 a 3,64 & 4,63 a 6,23 \\
\hline $\mathrm{m} \%$ & 168 & 0 & 16 & 0,73 & $-0,04$ & 3,92 & $-0,30$ a 0,30 & 2,48 a 3,62 & 4,67 a 6,27 \\
\hline CTC & 167 & 39 & 82 & 1,04 & 0,06 & 3,96 & $-0,30$ a 0,30 & 2,48 a 3,62 & 4,67 a 6,27 \\
\hline V\% & 167 & 24 & 71 & 0,18 & $-0,42$ & 4,75 & $-0,30$ a 0,30 & 2,48 a 3,62 & 4,67 a 6,27 \\
\hline $\mathrm{Mn}$ & 163 & 1,2 & 77,8 & 1,25 & 0,36 & 3,89 & $-0,31$ a 0,31 & 2,47 a 3,64 & 4,63 a 6,23 \\
\hline $\mathrm{Fe}$ & 158 & 8,6 & 33,2 & 0,45 & 0,22 & 4,62 & $-0,31$ a 0,31 & 2,47 a 3,64 & 4,63 a 6,23 \\
\hline $\mathrm{Cu}$ & 160 & 0,5 & 5,3 & 1,43 & 0,77 & 3,93 & $-0,31$ a 0,31 & 2,47 a 3,64 & 4,63 a 6,23 \\
\hline $\mathrm{Zn}$ & 166 & 0,2 & 1,4 & 0,80 & 0,18 & 4,44 & $-0,30$ a 0,30 & 2,48 a 3,62 & 4,67 a 6,27 \\
\hline B & 170 & 0,12 & 0,42 & 0,19 & $-1,12$ & 3,75 & $-0,30$ a 0,30 & 2,48 a 3,62 & 4,67 a 6,27 \\
\hline
\end{tabular}

* para um nível de significância igual a 95\%.

Onde: $\mathrm{n}=$ Número de amostras; A/s = Amplitude total dos dados (A) sobre Desvio padrão (s).

A variável argila é a que possui mais dados discrepantes (“outliers”); de 170 amostras, 147 não apresentaram dados discrepantes ("outliers"), como pode ser observado na Tabela 4. E a sua assimetria $(0,40)$ está fora do intervalo estabelecido pela Tabela 5, o mesmo acontece com a sua curtose $(0,41)$ e apenas a relação da $\mathrm{A} / \mathrm{s}$ que é de 4,72 , está dentro do intervalo proposto.

A variável boro (B) foi a única que não apresentou dados discrepantes (“outliers"). E a sua assimetria $(0,19)$ encontra-se dentro do intervalo proposto pela Tabela 5 para “n” igual a 170 , mas a curtose $(-1,12)$ e a relação $A / s(3,75)$ estão fora do limite de intervalos propostos.

De acordo com a Tabela 5, pode-se dizer que as variáveis que estão mais próximas a uma distribuição normal são: óleo (\%E.E.M.S.), proteína (\%P.B.M.S.), acidez potencial $(\mathrm{H}+\mathrm{Al})$, potássio $(\mathrm{K})$, porcentagem de saturação por bases $(\mathrm{V} \%)$ e ferro $(\mathrm{Fe})$.

Comparando-se os valores da assimetria, curtose e da relação entre a amplitude 
total dos dados sobre desvio padrão (A/s) com seus respectivos limites de intervalos propostos para cada variável na Tabela 5, pode-se dizer que está comprovado que as variáveis em estudo não apresentam uma distribuição normal dos dados, ficando clara a importância da análise geoestatística.

\subsection{Análise de regressão linear múltipla}

O coeficiente de determinação pode ser interpretado pelo sentido relativo quando assumir valores entre 0 e 1. Depois de multiplicado por 100 revela um percentual de ajustamento.

Normalmente um ajustamento entre 65 e $75 \%$ pode ser considerado regular; entre 75 e $85 \%$ pode ser considerado bom; acima de $85 \%$ deve ser considerado ótimo. Abaixo de 60\% demonstra que a variável independente " $\mathrm{x}$ " não explica com segurança a variação de "y". Nesse caso deve ser encontrada outra causa (variável independente x) que melhor explique ou justifique a variação de "y" (Vanni, 1998).

Como as variáveis óleo (\%E.E.M.S.) e proteína (\%P.B.M.S.) não apresentaram estrutura de semivariograma, resolveu-se, inicialmente, fazer a regressão por programas de estatística convencional (Minitab 13.2), a qual leva em consideração apenas os pontos amostrados e não como o programa Idrisi32 que realiza regressões pixel a pixel dos mapas interpolados levando-se em consideração a posição espacial dos dados.

Para verificar qual a contribuição de cada variável utilizada neste estudo na produção de óleo (\%E.E.M.S.) e proteína (\%P.B.M.S.), foram utilizadas as seguintes variáveis:

\section{Variáveis dependentes}

- óleo (\%E.E.M.S.) e proteína (\%P.B.M.S.).

\section{$\underline{\text { Variáveis independentes }}$}

- areia, argila, silte, $\mathrm{pH} \mathrm{CaCl} 2, \mathrm{H}+\mathrm{Al}, \mathrm{Al}, \mathrm{M} . \mathrm{O} ., \mathrm{Ca}, \mathrm{Mg}, \mathrm{K}, \mathrm{P}, \mathrm{S}, \mathrm{SB}, \mathrm{m} \%$, CTC, V\%, Mn, Fe, Cu, Zn e B. 
Para os modelos de regressão encontrados, os resultados estão contidos na Tabela 6, resumindo os modelos encontrados para variável óleo (\%E.E.M.S.).

Tabela 6. Modelos de regressão encontrados para variável óleo (\%E.E.M.S.)

\begin{tabular}{|c|c|c|c|c|c|c|}
\hline Entra & Sai & & Modelos de Regressão (Y = \%E.E.M.S.) & $r^{2}$ & $\mathbf{F}_{\text {calc. }}$ & $\mathbf{F}_{\text {tab. }}$ \\
\hline $\mathrm{m} \%$ & - & $\mathbf{Y}=$ & $19,4-0,096 \mathrm{~m} \%$ & 2,1 & 3,15 & 3,09 \\
\hline SB & - & $\mathbf{Y}=$ & $22,6-0,224 \mathrm{~m} \%-0,111 \mathrm{SB}$ & 5,4 & 3,94 & 3,08 \\
\hline K & - & $\mathbf{Y}=$ & $22,0-0,247 \mathrm{~m} \%-0,123 \mathrm{SB}+1,03 \mathrm{~K}$ & 7,2 & 3,64 & 2,70 \\
\hline $\mathrm{Al}$ & - & $\mathbf{Y}=$ & $22,4-0,412 \mathrm{~m} \%-0,141 \mathrm{SB}+0,950 \mathrm{~K}+0,857 \mathrm{Al}$ & 7,8 & 3,17 & 2,46 \\
\hline S & - & $\mathbf{Y}=$ & $\begin{array}{l}22,0+0,877 \mathrm{Al}+0,117 \mathrm{~S}+0,884 \mathrm{~K}-0,429 \mathrm{~m} \%- \\
0,147 \mathrm{SB}\end{array}$ & 8,1 & 2,79 & 2,31 \\
\hline
\end{tabular}

Onde: $r^{2}=$ Coeficiente de determinação $(\%) ; \mathrm{F}_{\text {calc. }}=\mathrm{F}$ calculado e $\mathrm{F}_{\text {tab. }}=\mathrm{F}$ tabelado ao nível de $5 \%$ de probabilidade.

Com base na Tabela 6, pode-se verificar que a primeira variável a entrar no modelo é a porcentagem de saturação de alumínio ( $\mathrm{m} \%$ ), explicando $2,1 \%$ da produção de óleo (\%E.E.M.S.). Nos passos seguintes, entram soma de bases (SB), potássio (K), alumínio (Al) e enxofre (S). Portanto, considera-se o modelo final como sendo aquele com 5 variáveis:

$$
\mathrm{Y}=22,0+0,877 \mathrm{Al}+0,117 \mathrm{~S}+0,884 \mathrm{~K}-0,429 \mathrm{~m} \%-0,147 \mathrm{SB} \text {, explicando }
$$

$8,1 \%$ do teor de óleo.

A análise de variância aplicada, dando um F calculado igual a 2,79, portanto superior ao $\mathrm{F}$ tabelado $\left(\mathrm{F}_{0,05,5,97}=2,31\right)$, indicou que os dados obedecem ao modelo de análise de regressão linear múltipla, ou seja, que as variáveis independentes reduzem a variação da variável dependente, mas, por sua vez, com um ajustamento muito baixo, considerando-se o limite imposto por Vanni, (1998), de 60\% como mínimo para que uma variável independente explique com segurança a variação de uma variável dependente, portanto, esse modelo encontrado não deve ser aceito.

Cabe ressaltar que as variáveis areia e argila não entraram neste estudo, pois possuem uma alta correlação com a variável silte, e seu coeficiente de determinação foi menor que da variável silte.

Na Tabela 7, tem-se um resumo dos modelos de regressão encontrados com o 
mesmo método da Tabela 6, para a variável proteína (\%P.B.M.S.).

Tabela 7. Modelos de regressão encontrados para variável proteína (\%P.B.M.S.)

\begin{tabular}{|c|c|c|c|c|c|}
\hline Entra & Sai & Modelos de Regressão (Y = \%P.B.M.S.) & $r^{2}$ & $\mathbf{F}_{\text {calc. }}$ & $\mathbf{F}_{\text {tab. }}$ \\
\hline $\mathrm{m} \%$ & & $\mathbf{Y}=40,9+0,109 \mathrm{~m} \%$ & 3,7 & 4,96 & 3,94 \\
\hline K & & $\mathbf{Y}=41,8+0,117 \mathrm{~m} \%-0,859 \mathrm{~K}$ & 5,0 & 3,70 & 3,08 \\
\hline $\mathrm{H}+\mathrm{Al}$ e $\mathrm{P}$ & K & $\mathbf{Y}=43,6+0,174 \mathrm{~m} \%-0,083 \mathrm{H}+\mathrm{Al}-0,086 \mathrm{P}$ & 6,8 & 3,46 & 2,70 \\
\hline M.O. & & $\begin{aligned} \mathbf{Y}= & 40,7+0,254 \mathrm{~m} \%-0,140 \mathrm{H}+\mathrm{Al}-0,084 \mathrm{P}+ \\
& 0,226 \text { M.O. }\end{aligned}$ & 8,3 & 3,30 & 2,46 \\
\hline K & & $\begin{aligned} \mathbf{Y}= & 41,1+0,260 \mathrm{~m} \%-0,136 \mathrm{H}+\mathrm{Al}-0,077 \mathrm{P}+ \\
& 0,238 \text { M.O. }-0,763 \mathrm{~K}\end{aligned}$ & 9,1 & 3,05 & 2,31 \\
\hline $\mathrm{V} \%$ e SB & $\mathrm{H}+\mathrm{Al}$ & $\begin{aligned} \mathbf{Y}= & 33,6+0,273 \mathrm{~m} \%-0,078 \mathrm{P}+0,280 \text { M.O. }- \\
& 0,805 \mathrm{~K}-0,191 \mathrm{SB}+0,164 \mathrm{~V} \%\end{aligned}$ & 9,7 & 2,83 & 2,19 \\
\hline $\mathrm{Cu}$ & & $\begin{aligned} \mathbf{Y}= & 33,6+0,272 \mathrm{~m} \%-0,076 \mathrm{P}+0,262 \mathrm{M} . \mathrm{O} .- \\
& 0,862 \mathrm{~K}-0,231 \mathrm{SB}+0,184 \mathrm{~V} \%+0,301 \mathrm{Cu}\end{aligned}$ & 9,9 & 2,60 & 2,10 \\
\hline $\mathrm{Fe}$ & & $\begin{aligned} \mathbf{Y}= & 34,7+0,278 \mathrm{~m} \%-0,070 \mathrm{P}+0,264 \mathrm{M} . \mathrm{O} .- \\
& 1,040 \mathrm{~K}-0,249 \mathrm{SB}+0,190 \mathrm{~V} \%+0,341 \mathrm{Cu}- \\
& 0,074 \mathrm{Fe}\end{aligned}$ & 10,2 & 2,45 & 2,04 \\
\hline
\end{tabular}

Onde: $r^{2}=$ Coeficiente de determinação (\%); $\mathrm{F}_{\text {calc. }}=\mathrm{F}$ calculado e $\mathrm{F}_{\text {tab. }}=\mathrm{F}$ tabelado ao nível de $5 \%$ de probabilidade.

Com base na Tabela 7, podemos verificar que a primeira variável a entrar no modelo é a porcentagem de saturação de alumínio ( $\mathrm{m} \%$ ), explicando 3,7\% da produção de proteína (\%P.B.M.S). Nos passos seguintes, entram fósforo (P), matéria orgânica (M.O.), potássio (K), soma de bases (SB), porcentagem de saturação por bases (V\%), cobre $(\mathrm{Cu})$ e ferro $(\mathrm{Fe})$. Portanto, considerando-se o modelo final como sendo aquele com 8 variáveis:

$$
\mathrm{Y}=34,7+0,278 \mathrm{~m} \%-0,0697 \mathrm{P}+\text { 0,264 M.O. - 1,04 K - 0,249 SB + 0,190 }
$$

$\mathrm{V} \%+0,341 \mathrm{Cu}-0,0742 \mathrm{Fe}$, explicando $10,2 \%$ do teor de proteína.

A análise de variância aplicada, para a variável proteína, dando um F calculado igual a 2,45, portanto superior ao $\mathrm{F}$ tabelado $\left(\mathrm{F}_{0,05}, 8,94=2,04\right)$, indicou que os dados obedecem ao modelo de análise de regressão linear múltipla, ou seja, que as variáveis independentes reduzem a variação da variável dependente, mas assim como a variável óleo, seu ajustamento não foi explicado com segurança e seu modelo não deve ser aceito.

Como o ajustamento dos dados para as variáveis óleo (\%E.E.M.S.) e proteína 
(\%P.B.M.S.) foram baixos pela estatística convencional resolveu-se utilizar técnicas de interpolação pelo método do inverso do quadrado da distância para essas variáveis que não apresentaram estrutura de semivariograma (efeito pepita puro), e fazer a regressão pelo programa Idrisi32 dos mapas interpolados com as mesmas variáveis que resultou em um melhor coeficiente de determinação por estatística convencional mencionada nas Tabelas 6 e 7. O coeficiente encontrado para óleo (\%E.E.M.S.) foi de 19,6\% dando um F calculado de 80,15 , superior ao $\mathrm{F}$ tabelado $(5,1613)=79,55$ e a proteína (\%P.B.M.S.) foi de $45,30 \%$ com um $\mathrm{F}$ calculado de 168,43 , também superior ao $\mathrm{F}$ tabelado $(8,1610)=$ 168,13 , indicando que os dados obedecem aos modelos de regressão linear múltipla, mas, mesmo com um aumento significativo no ajustamento, as variáveis independentes não explicaram com segurança a variação das variáveis dependentes (óleo e proteína), mostrando-se neste caso, que se deve encontrar outra causa (variável independente) que melhor explique ou justifique a variação (Vanni, 1998).

\subsection{Análise geoestatística dos dados amostrados}

A Tabela 8 ilustra o resultado da análise geoestatística para os dados da variável atributos da soja e do solo, efetuado pelo método da amostragem regular. Estão listados todos os parâmetros que foram utilizados para a seleção do melhor modelo do semivariograma e para a interpolação por krigagem.

Tabela 8. Resultados da análise geoestatística das variáveis em estudo

\begin{tabular}{|c|c|c|c|c|c|c|c|}
\hline Variáveis & Modelos & Direções & Co & $\mathrm{Co}+\mathrm{C}$ & $\mathbf{a}(\mathbf{m})$ & $\begin{array}{c}\mathrm{Co} / \mathrm{Co}+\mathrm{C} \\
(\%)\end{array}$ & $\mathbf{R}^{2}(\%)$ \\
\hline \%E.E.M.S. & \multicolumn{7}{|c|}{ Modelo Efeito Pepita Puro $(\mathrm{Co}=5,69)$} \\
\hline \%P.B.M.S. & \multicolumn{7}{|c|}{ Modelo Efeito Pepita Puro $(\mathrm{Co}=4,15)$} \\
\hline Areia & Esférico & $45^{\circ}$ & 400,000 & 2300,0000 & 150,0 & 17,4 & 99,0 \\
\hline Argila & \multicolumn{7}{|c|}{ Modelo Efeito Pepita Puro $(\mathrm{Co}=1600,63)$} \\
\hline Silte & Esférico & $135^{\circ}$ & 830,000 & 1550,0000 & 300,0 & 53,5 & 89,0 \\
\hline $\mathrm{pH} \mathrm{CaCl}{ }_{2}$ & Gaussiano & Isotrópico & 0,114 & 0,1500 & 290,0 & 76,0 & 68,8 \\
\hline $\mathrm{H}+\mathrm{Al}$ & Gaussiano & Isotrópico & 20,900 & 79,1700 & 312,2 & 26,4 & 99,2 \\
\hline $\mathrm{Al}$ & Esférico & Isotrópico & 0,550 & 0,7000 & 120,0 & 78,6 & 50,4 \\
\hline M.O. & Esférico & $0^{\circ}$ & 0,800 & 7,0000 & 220,0 & 11,4 & 97,8 \\
\hline $\mathrm{Ca}$ & Esférico & $0^{\circ}$ & 12,000 & 24,0000 & 150,0 & 50,0 & 83,0 \\
\hline
\end{tabular}


Tabela 8. Resultados da análise geoestatística das variáveis em estudo

\begin{tabular}{|c|c|c|c|c|c|c|c|}
\hline Variáveis & Modelos & Direções & Co & $\mathrm{Co}+\mathrm{C}$ & $\mathbf{a}(\mathbf{m})$ & $\begin{array}{c}\mathrm{Co} / \mathrm{Co}+\mathrm{C} \\
(\%) \\
\end{array}$ & $\mathbf{R}^{2}(\%)$ \\
\hline $\mathrm{Mg}$ & Esférico & $0^{\circ}$ & 3,300 & 12,3000 & 195,0 & 26,8 & 89,5 \\
\hline K & Gaussiano & Isotrópico & 0,110 & 0,1750 & 250,0 & 62,9 & 64,0 \\
\hline $\mathrm{P}$ & Gaussiano & $0^{\circ}$ & 15,000 & 22,0000 & 280,0 & 68,2 & 61,1 \\
\hline S & Gaussiano & Isotrópico & 4,600 & 11,0000 & 380,0 & 41,8 & 94,3 \\
\hline SB & Esférico & $0^{\circ}$ & 21,500 & 75,0000 & 190,0 & 28,7 & 85,3 \\
\hline $\mathrm{m} \%$ & Esférico & $90^{\circ}$ & 11,700 & 19,0000 & 180,0 & 61,6 & 52,8 \\
\hline CTC & Esférico & $0^{\circ}$ & 5,800 & 190,0000 & 280,0 & 3,1 & 97,2 \\
\hline V\% & Gaussiano & $90^{\circ}$ & 80,000 & 120,0000 & 170,0 & 66,7 & 60,1 \\
\hline $\mathrm{Mn}$ & Gaussiano & $0^{\circ}$ & 126,000 & 1200,0000 & 270,0 & 10,5 & 100,8 \\
\hline $\mathrm{Fe}$ & Esférico & $0^{\circ}$ & 17,000 & 27,0000 & 120,0 & 63,0 & 46,3 \\
\hline $\mathrm{Cu}$ & Esférico & $90^{\circ}$ & 0,300 & 0,9000 & 120,0 & 33,3 & 97,3 \\
\hline $\mathrm{Zn}$ & Esférico & Isotrópico & 0,030 & 0,0756 & 45,0 & 39,7 & 27,3 \\
\hline B & \multicolumn{7}{|c|}{ Modelo Efeito Pepita Puro $(\mathrm{Co}=0,0067)$} \\
\hline
\end{tabular}

Na Tabela 8, pode-se observar que as variáveis, \%E.E.M.S., \%P.B.M.S., argila e B, não têm dependência espacial, podendo-se observar através da ilustração do mapa de variabilidade espacial (“Classed post - Equal number”) de cada variável representada pelas Figuras 23, 25, 29 e 69, respectivamente, com áreas cincundadas mostrando valores extremos muito próximos. Sendo, portanto, o semivariograma caracterizado pelo efeito pepita puro com Co igual à variância dos dados.

$\mathrm{O}$ parâmetro $\mathrm{R}^{2}$ ilustra o ajuste dos dados à reta de 45 graus obtido pela validação cruzada. Quanto maior o $\mathrm{R}^{2}$, melhor o modelo encontrado para descrever a variabilidade do atributo.

Segundo Cambardella et al. (1994), o efeito pepita é um parâmetro importante do semivariograma e indica a variabilidade inexplicada da correlação espacial, que pode ser devida a erros de medidas, ou a microvariação não detectada, considerando a distância de amostragem utilizada. Esse parâmetro pode ser expresso como porcentagem do patamar, já que é impossível quantificar a contribuição individual dos erros de medições ou da variabilidade (Trangmar et al., 1985). Neste estudo, o grau de dependência espacial das variáveis foi avaliado através da porcentagem do efeito pepita no patamar, segundo os níveis de classificação: forte quando o efeito pepita corresponde 
a um valor menor ou igual a $25 \%$ do patamar, dependência espacial moderada, quando o efeito pepita corresponde a um valor maior que $25 \%$ e menor ou igual a $75 \%$, e fraca quando maior que $75 \%$ do patamar (Cambardella et al., 1994).

O grau de dependência espacial dos semivariogramas ajustados foi considerado forte apenas para as variáveis areia, M.O., CTC e Mn, moderado para as variáveis silte, $\mathrm{H}+\mathrm{Al}, \mathrm{Ca}, \mathrm{Mg}, \mathrm{K}, \mathrm{P}, \mathrm{S}, \mathrm{SB}, \mathrm{m} \%, \mathrm{~V} \%, \mathrm{Fe}, \mathrm{Cu}$ e $\mathrm{Zn}$ e fraco para as variáveis $\mathrm{pH} \mathrm{CaCl}_{2} \mathrm{e}$ Al.

Os modelos do semivariogramas com efeito pepita pequeno (areia, M.O., CTC e Mn) mostram que toda a variabilidade espacial está sendo descrita adequadamente pelo modelo ajustado.

Pode-se observar que houve uma variação no alcance dos semivariogramas ajustados entre $45 \mathrm{~m}$ a $380 \mathrm{~m}$, mostrando que a distância interamostral utilizada para o mapeamento dos atributos foi adequada $(25 \mathrm{~m})$, exceto para as variáveis (\%E.E.M.S., \%P.B.M.S., argila e B) que não apresentaram dependência espacial, o que é indicado pelo efeito pepita puro, isso indica que para esses atributos deve-se adotar um espaçamento diferenciado de amostragem.

O modelo que se mostrou mais adequado para explicar a estrutura da variabilidade espacial dos atributos da soja e do solo foi o esférico, seguido pelo gaussiano. Várias pesquisas indicam o modelo esférico como o mais adaptado para descrever o comportamento de semivariogramas de atributos de solo e de plantas (Trangmar et al., 1987 e Salviano et al., 1998). E o ângulo do semivariograma anisotrópico mais predominante foi de 0 grau.

\subsubsection{Semivariograma e mapas dos atributos da soja e do solo}

O parâmetro $\mathrm{r}^{2}$, demonstrado nas figuras dos semivariogramas das variáveis, que teve dependência espacial (Figuras 26, 30, 32, 34, 36, 38, 40, 42, 44, 46, 48, 50, 52, $54,56,58,60,62$ e 64) ilustra o ajuste do modelo variográfico ao variograma experimental. Pode-se observar nos gráficos que todos os ajustes estão acima de 57\%, exceto as variáveis porcentagem de saturação por alumínio $(\mathrm{m} \%)$, porcentagem de 
saturação por bases (V\%) e ferro (Fe), respectivamente Figuras 52, 56 e 60 e para as variáveis com independência espacial que não tiveram ajuste.

Obtidos os parâmetros dos semivariogramas dos atributos mapeados pela análise geoestatística, realizou-se a elaboração dos mapas das variáveis pelo método de interpolação por krigagem no GS+, para depois fazer a sobreposição (“overlay”) deste mapa com o mapa em três dimensões no Surfer 8.0, exceto para as variáveis com efeito pepita puro (\%E.E.M.S., \%P.B.M.S., argila e B) para as quais foram elaborados mapas de variabilidade espacial no Surfer 8.0 e circundados alguns valores para demonstrar valores extremos próximos, o que caracteriza a independência espacial.

A criação dos mapas com uma tonalidade de cor em degradé, e a escolha da cor mais escura para os teores mais altos, favoreceu a visualização e a comparação com outros mapas de variáveis diferentes quanto a distribuição espacial dos teores encontrados.

As Figuras 22 a 67 ilustram os semivariogramas, mapas de variabilidade espacial de variáveis com efeito pepita puro e mapas interpolados dos atributos do solo com dependência espacial. 


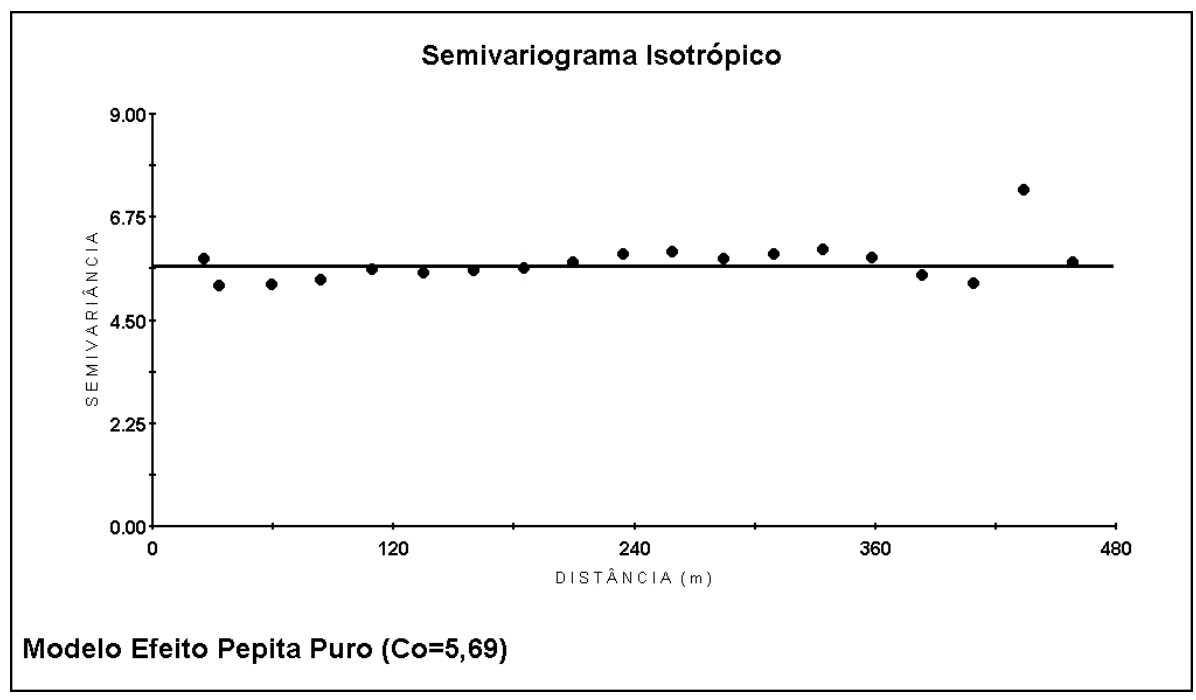

Figura 22 - Semivariograma da variável óleo (\%E.E.M.S.) e a representação do resultado da análise geoestatística

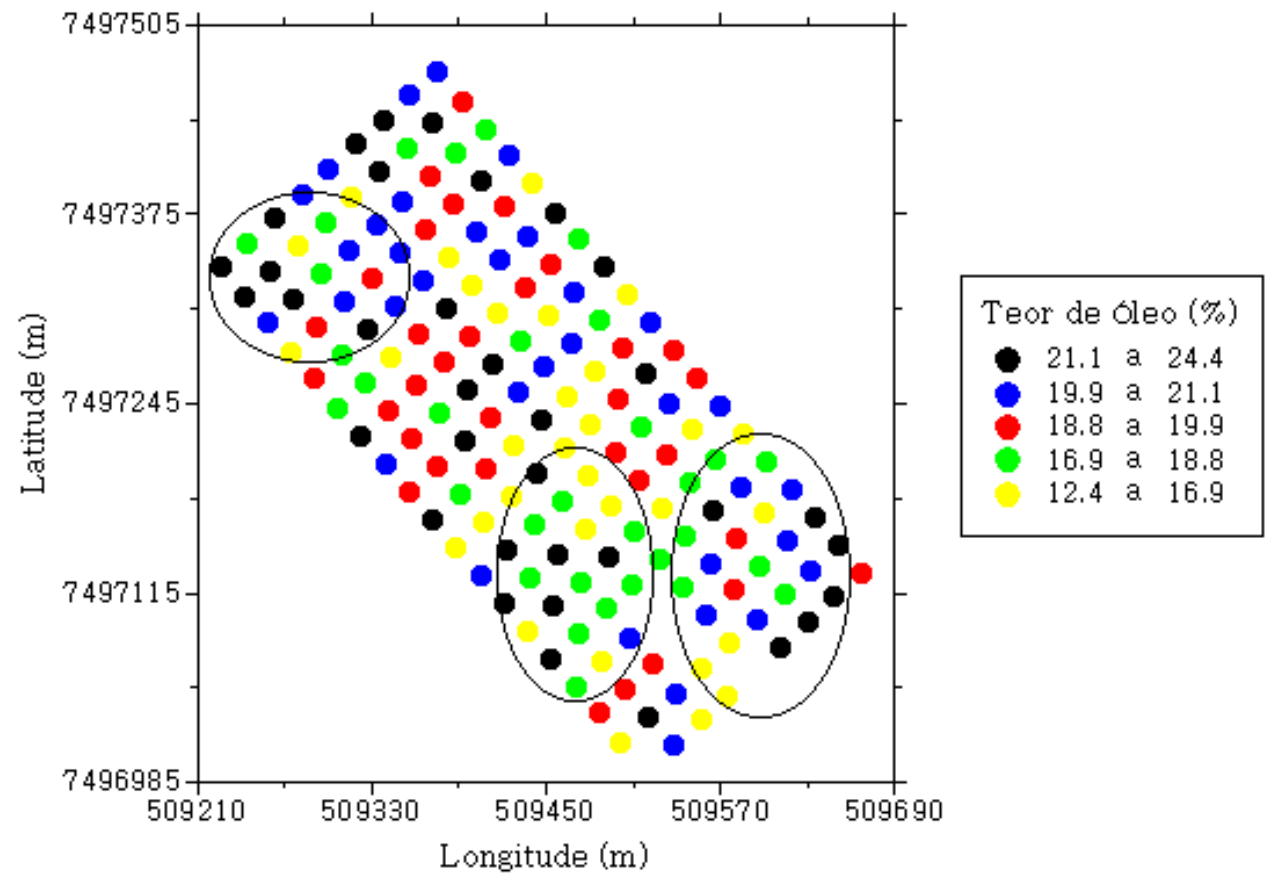

Figura 23 - Ilustração do mapa de variabilidade espacial (“Classed post - Equal number”) da variável óleo (\%E.E.M.S.) com áreas circundadas mostrando valores extremos muito próximos, o que acabou contribuindo para causar a independência espacial 


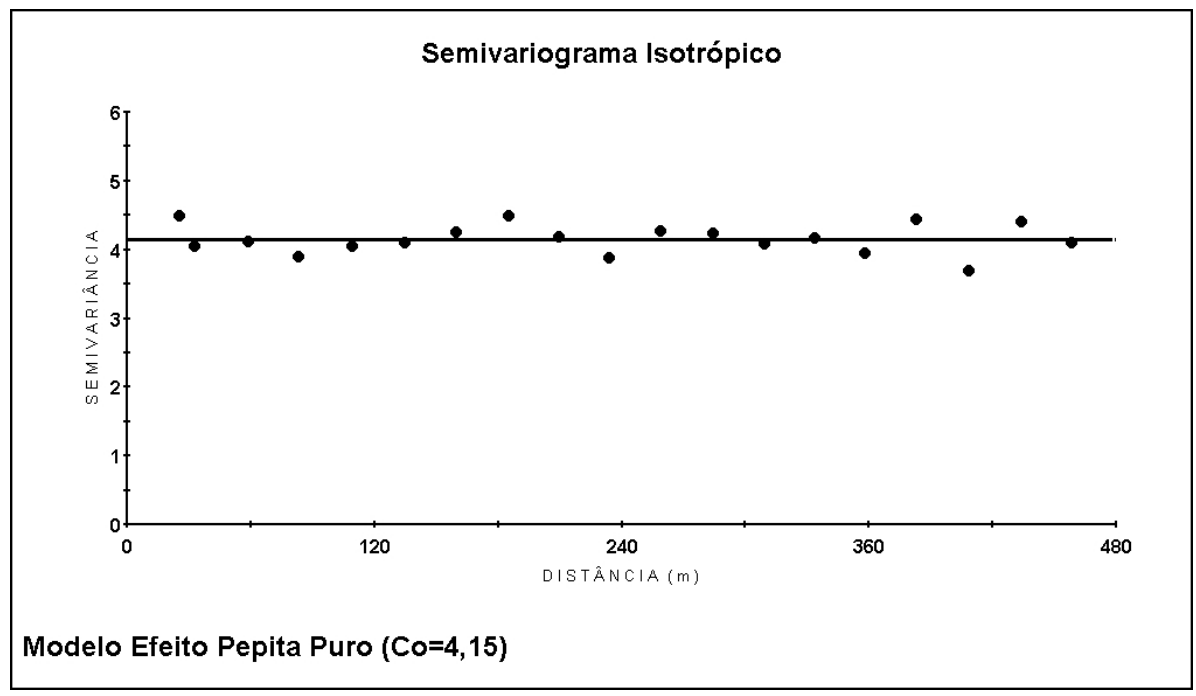

Figura 24 - Semivariograma da variável proteína (\%P.B.M.S.) e a representação do resultado da análise geoestatística

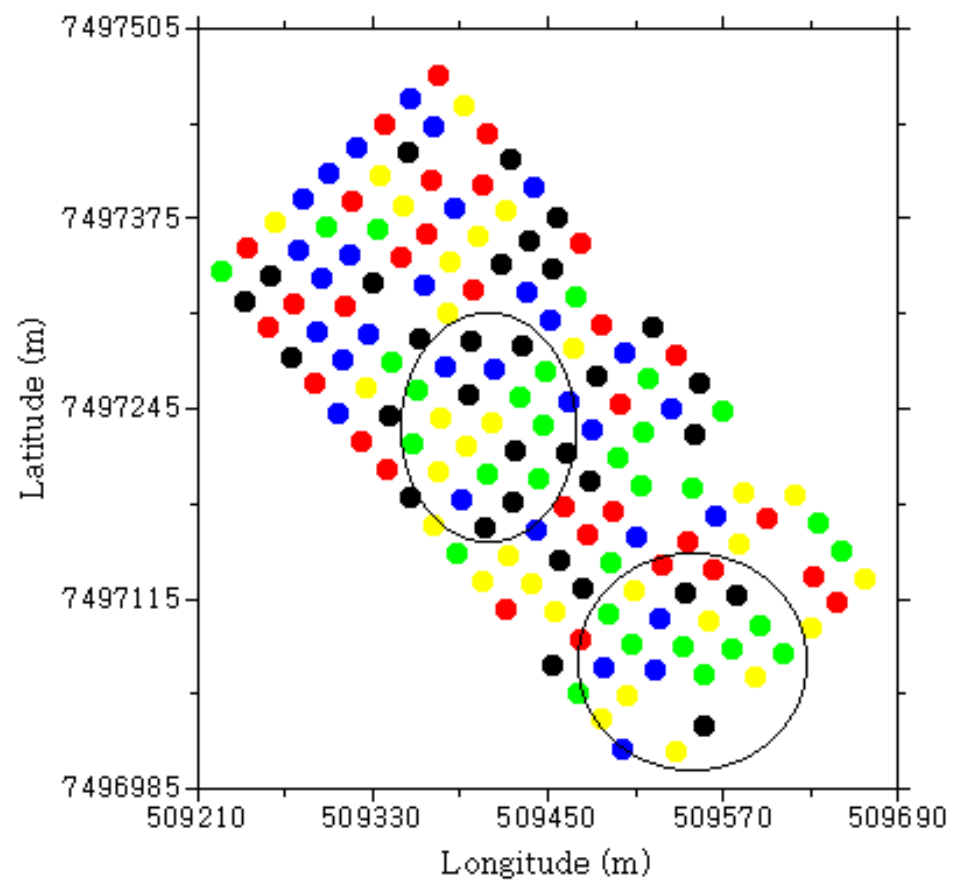

Teor de Proteina (\%)

- 43.04 a 46.79

42.15 a 43.04

41.29 a 42.15

39.65 a 41.29

35.79 a 39.65

Figura 25 - Ilustração do mapa de variabilidade espacial (“Classed post - Equal number”) da variável proteína (\%P.B.M.S.) com áreas circundadas mostrando valores extremos muito próximos, o que acabou contribuindo para causar a independência espacial 


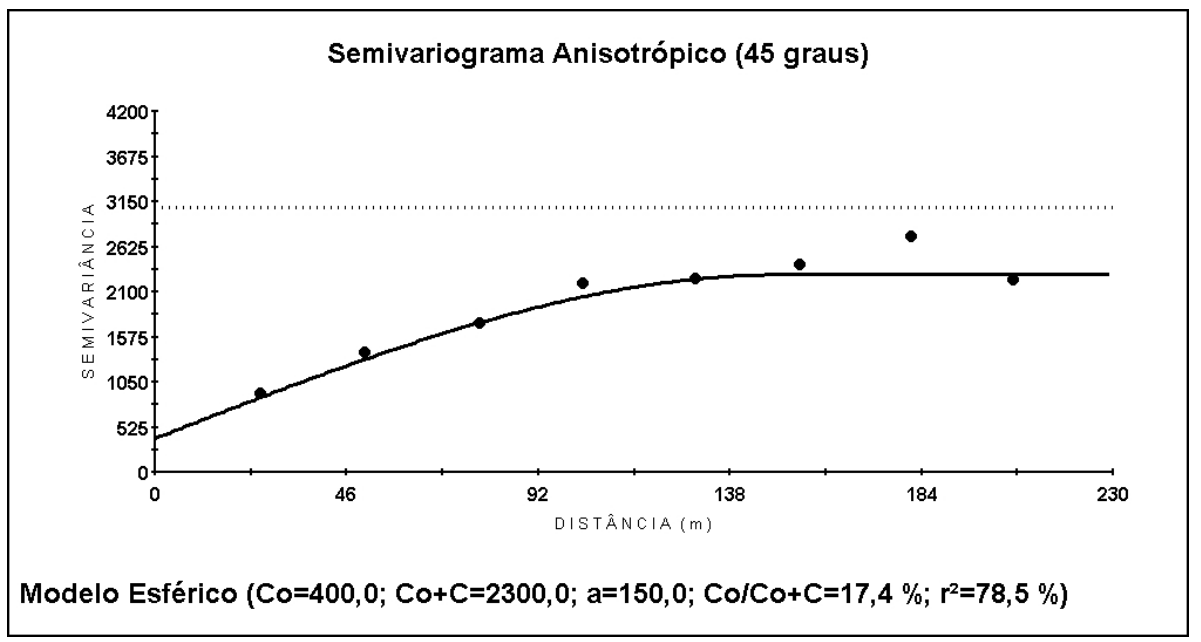

Figura 26 - Semivariograma da variável areia e a representação do resultado da análise geoestatística

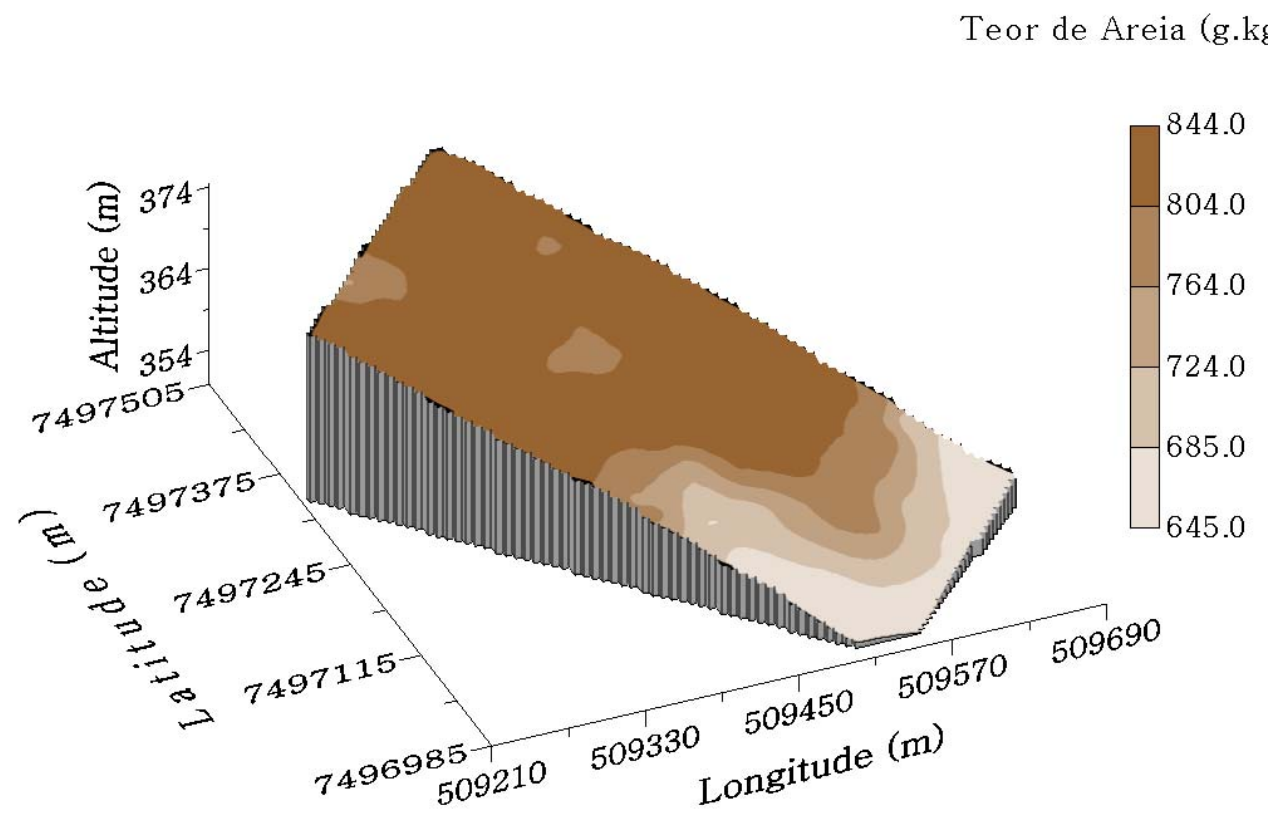

Figura 27 - Ilustração da Interpolação por krigagem da variável areia e a sobreposição (“overlay”) com a altitude da área experimental 


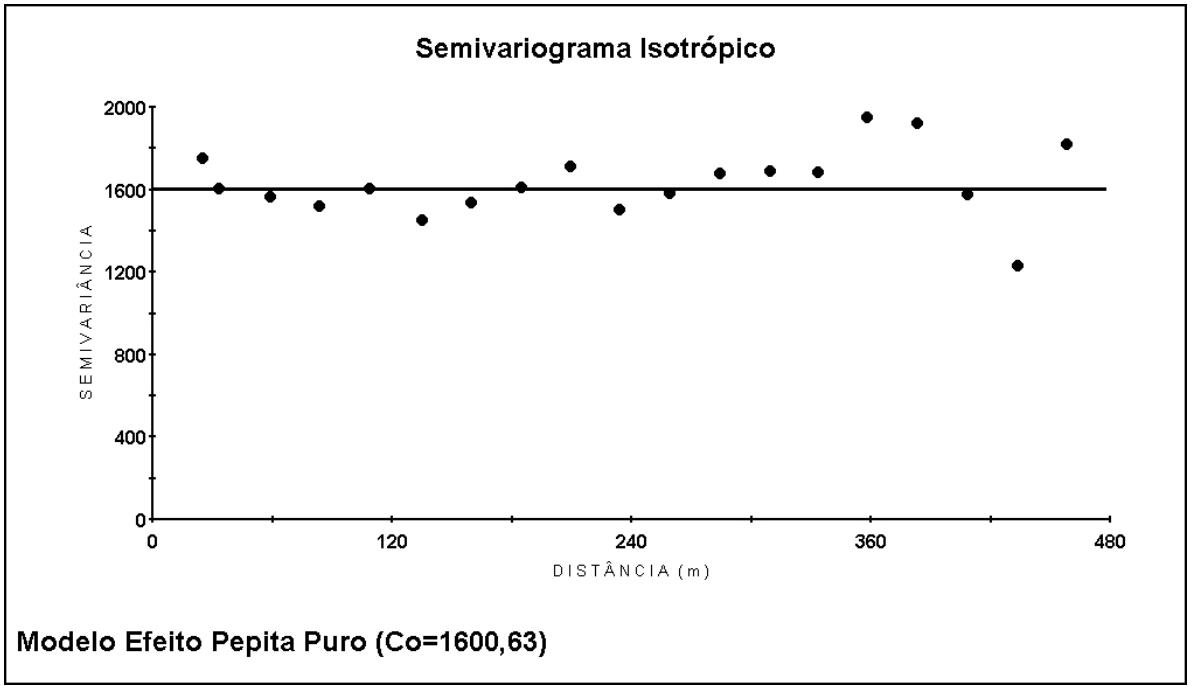

Figura 28 - Semivariograma da variável argila e a representação do resultado da análise geoestatística

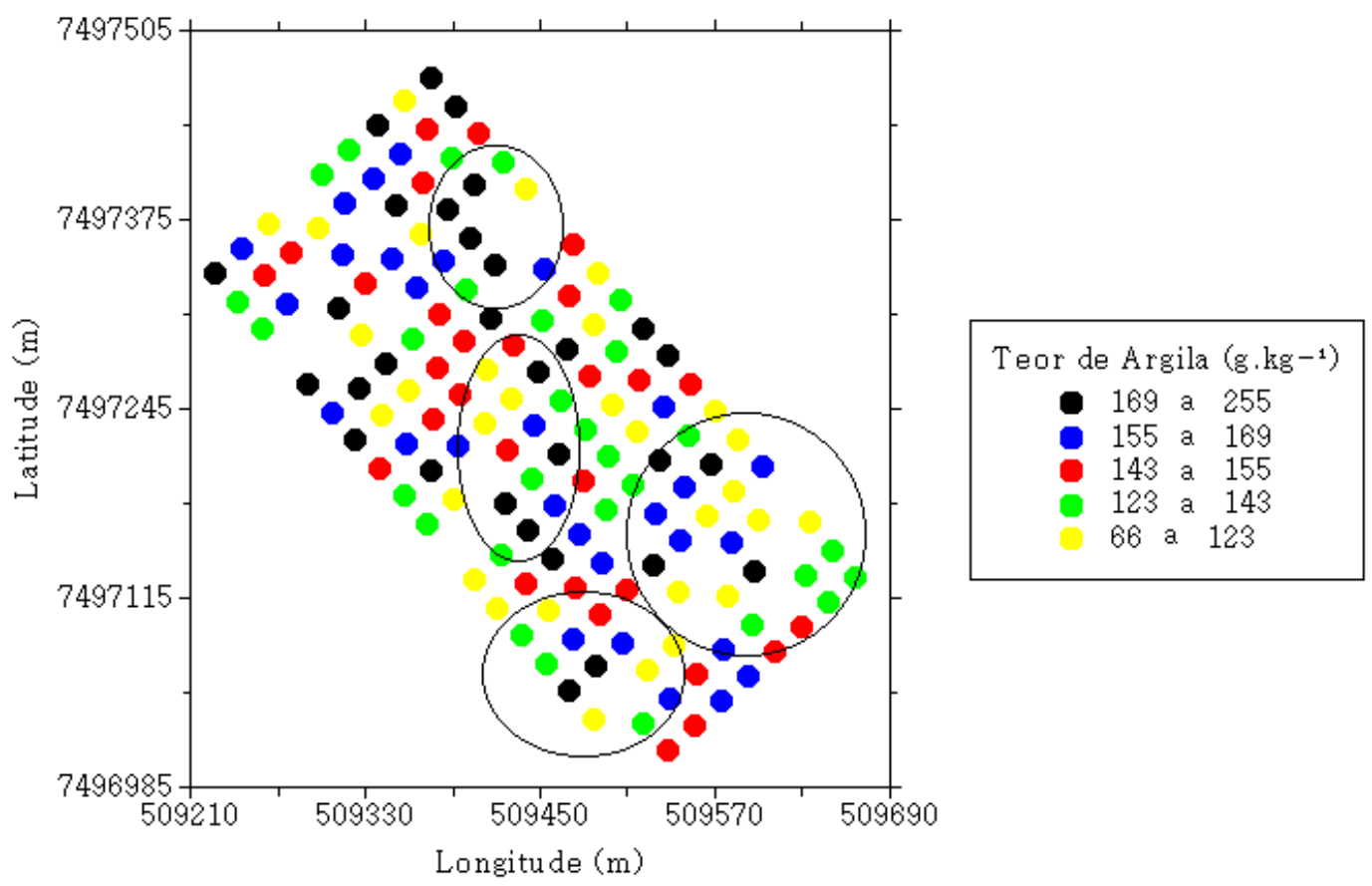

Figura 29 - Ilustração do mapa de variabilidade espacial da variável argila ("Classed post - Equal number”) com áreas circundadas mostrando valores extremos muito próximos, o que acabou contribuindo para causar a independência espacial 


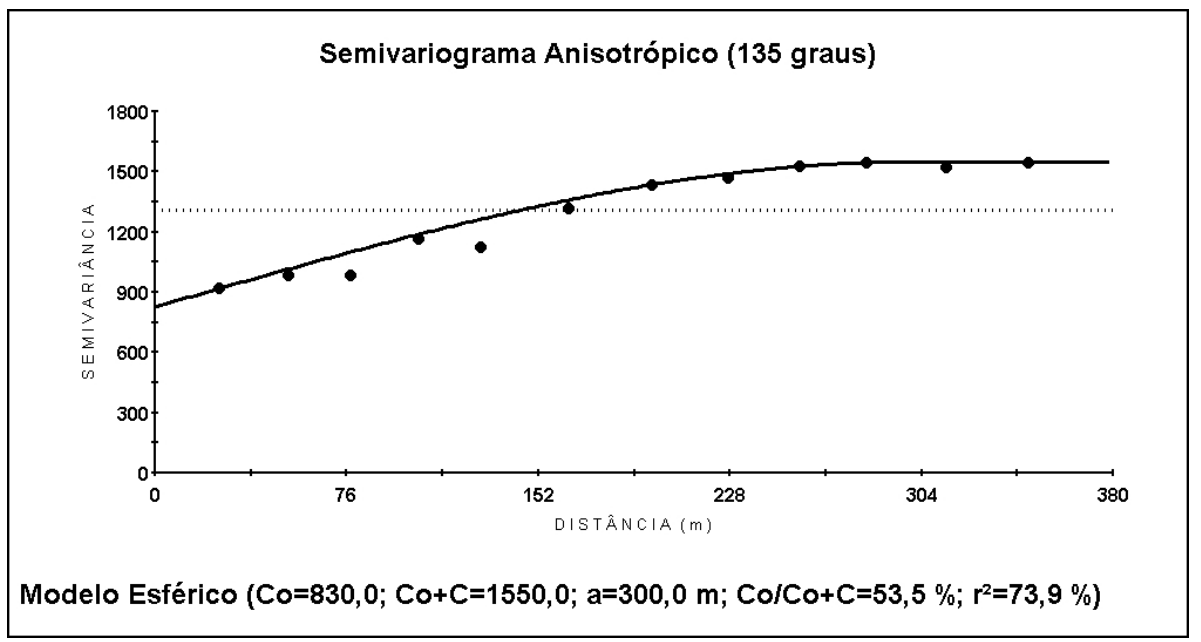

Figura 30 - Semivariograma da variável silte e a representação do resultado da análise geoestatística

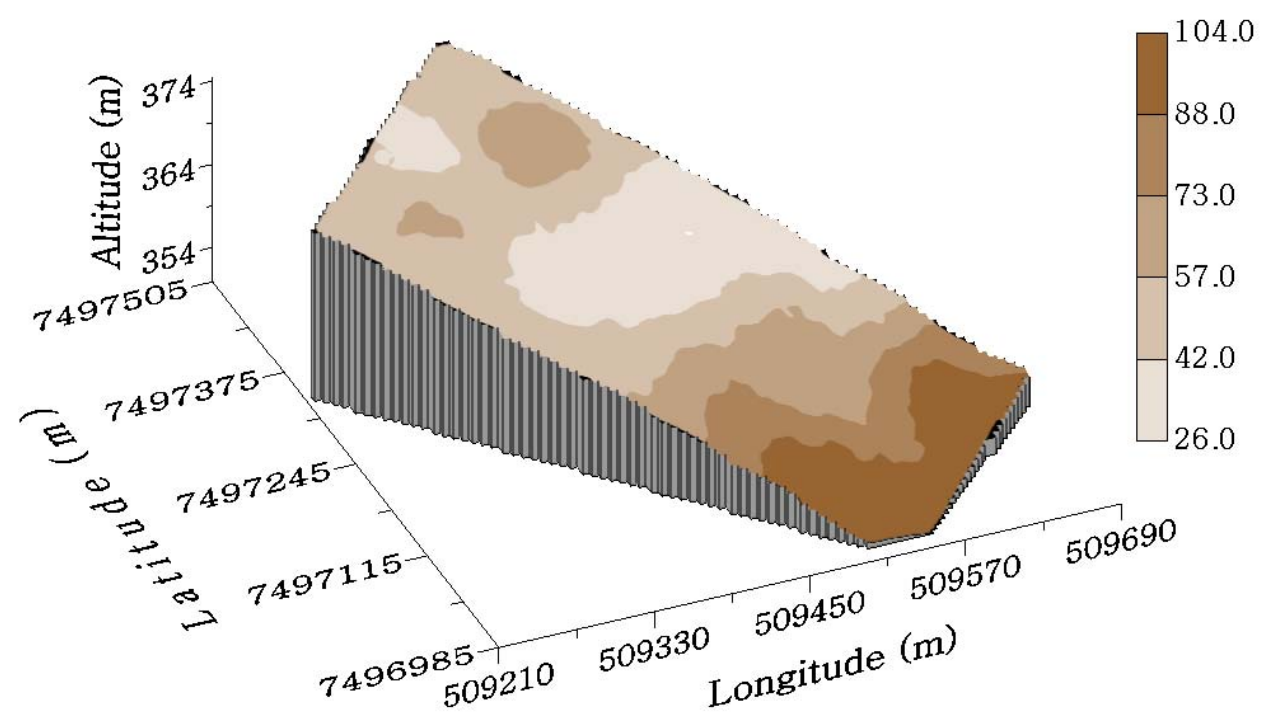

Figura 31 - Ilustração da Interpolação por krigagem da variável silte e a sobreposição (“overlay”) com a altitude da área experimental 


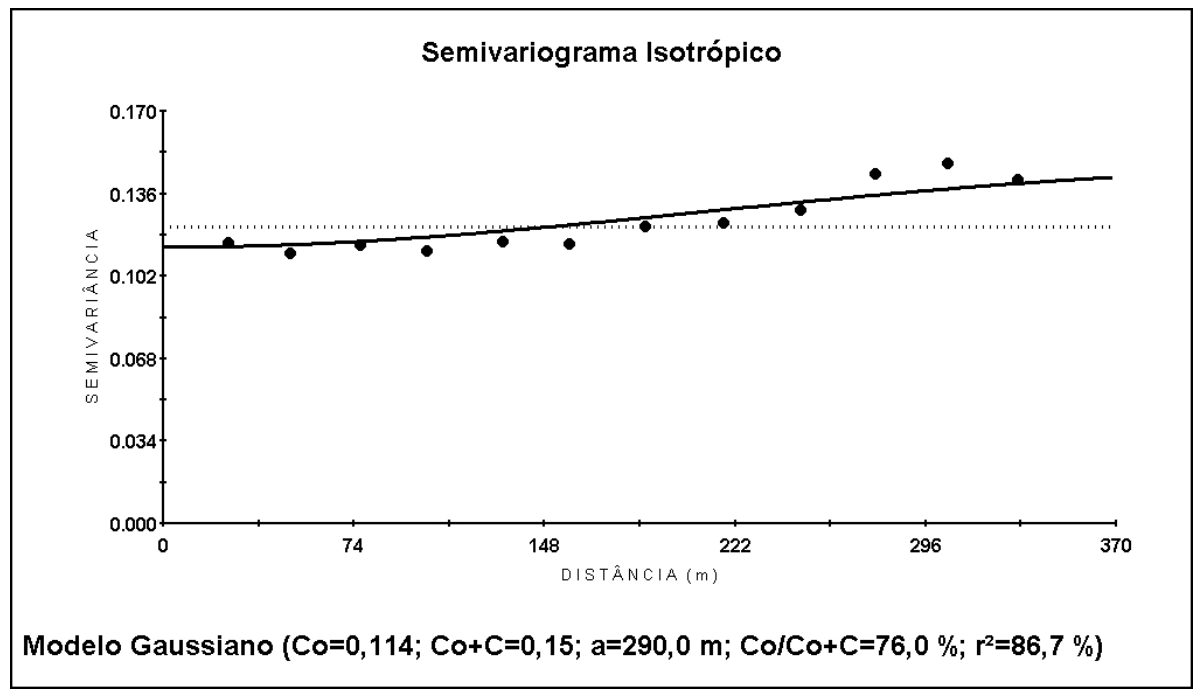

Figura 32 - Semivariograma da variável $\mathrm{pH} \mathrm{CaCl}_{2}$ e a representação do resultado da análise geoestatística

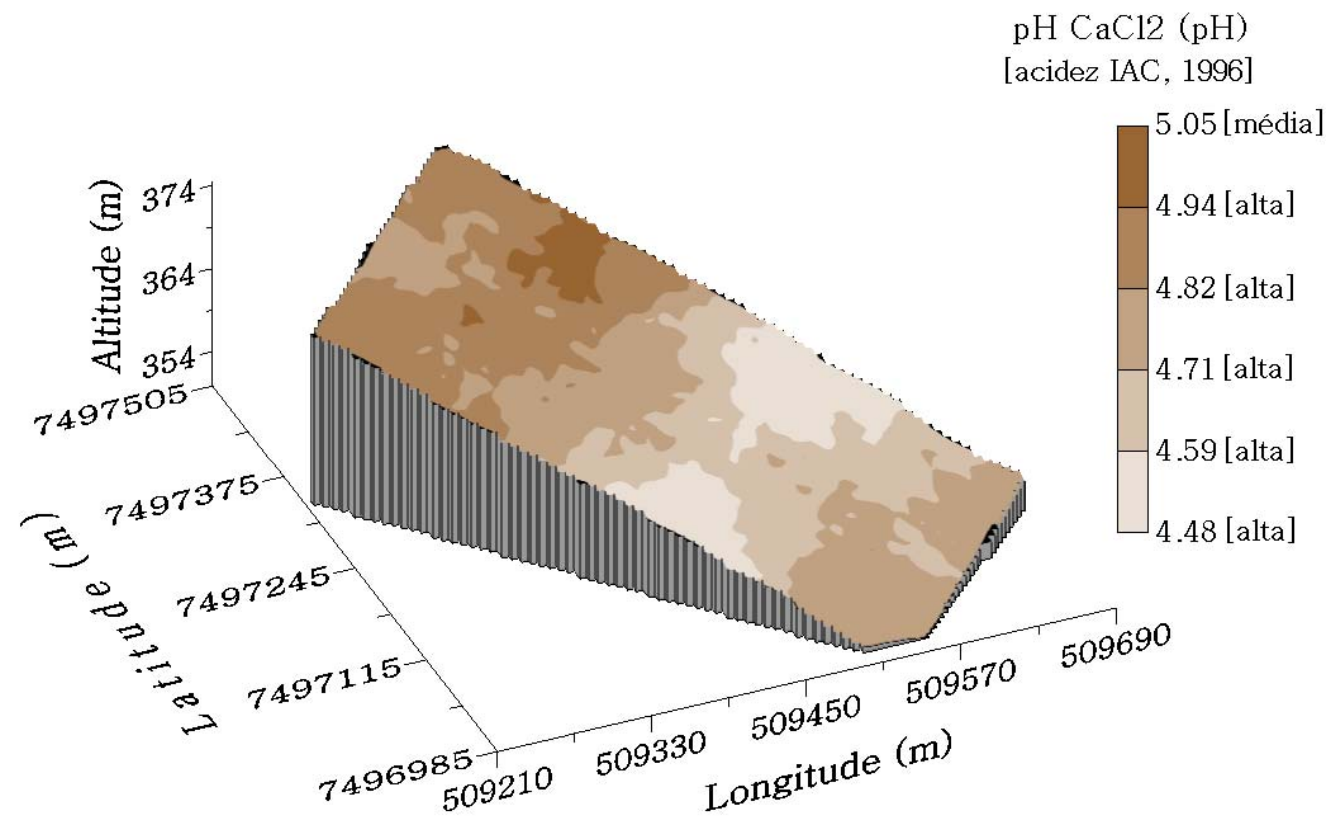

Figura 33 - Ilustração da Interpolação por krigagem da variável $\mathrm{pH} \mathrm{CaCl}_{2}$ e a sobreposição (“overlay”) com a altitude da área experimental 


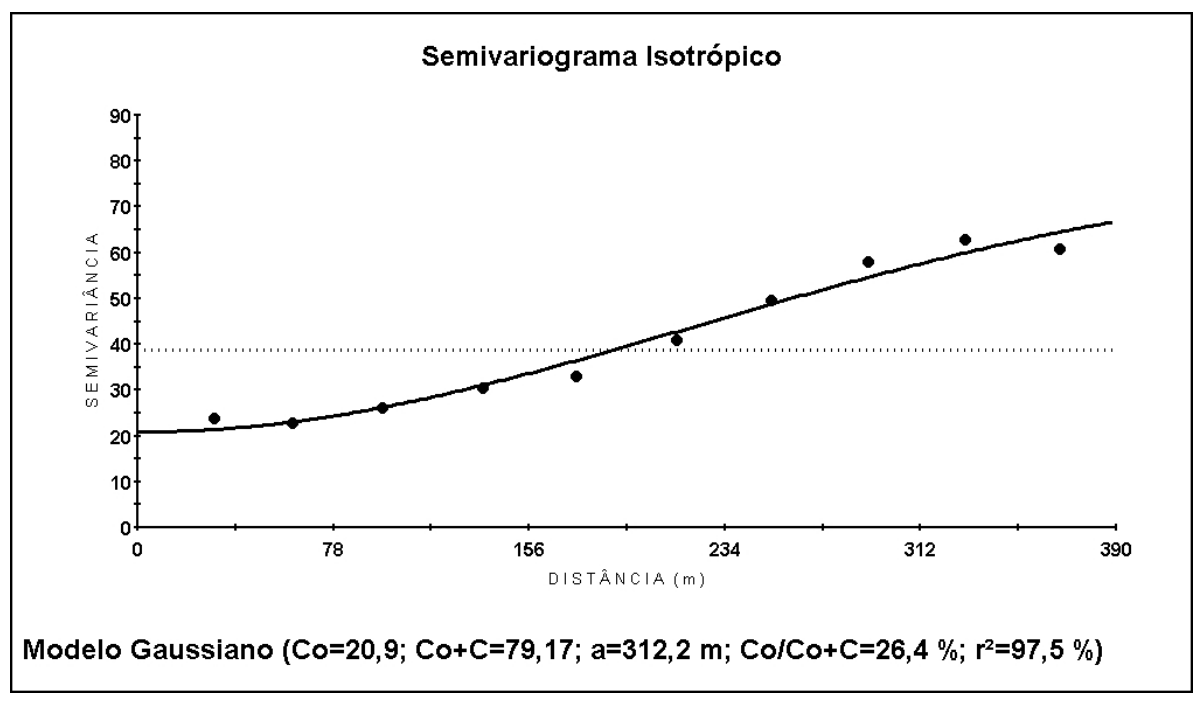

Figura 34 - Semivariograma da variável acidez potencial $(\mathrm{H}+\mathrm{Al})$ e a representação do resultado da análise geoestatística

Teor de $\mathrm{H}+\mathrm{Al}\left(\right.$ mmolc. $\left.\mathrm{dm}^{-3}\right)$

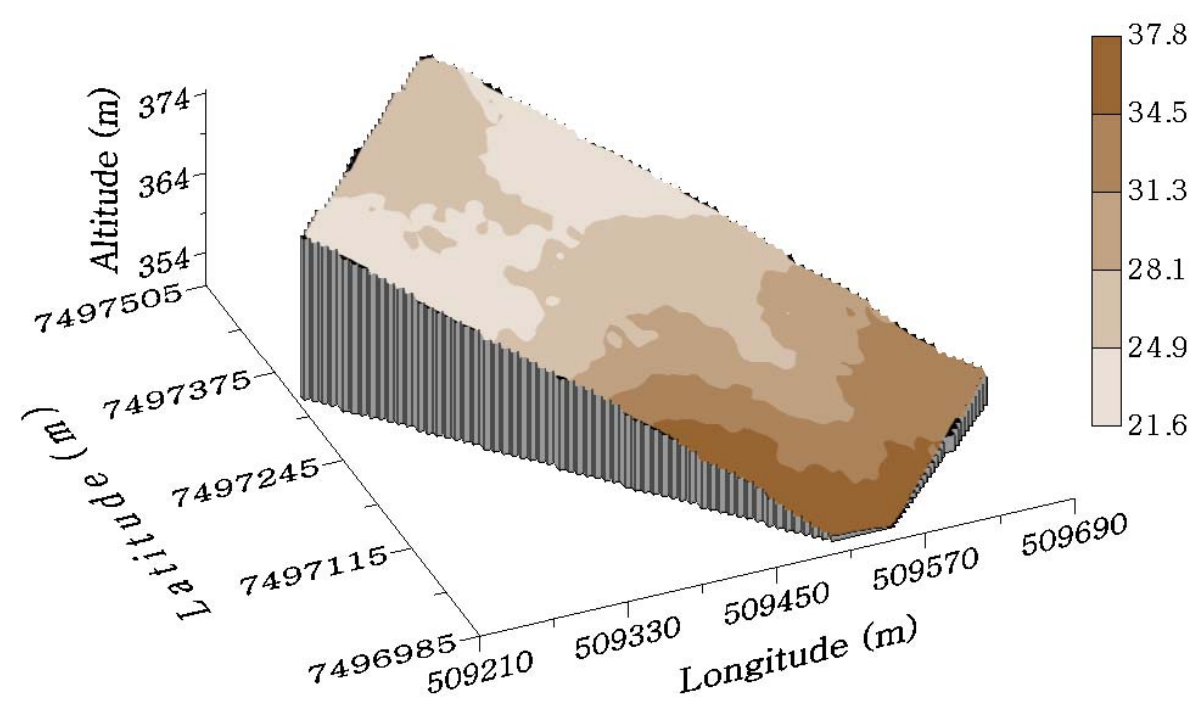

Figura 35 - Ilustração da Interpolação por krigagem da variável acidez potencial $(\mathrm{H}+\mathrm{Al})$ e a sobreposição (“overlay”) com a altitude da área experimental 


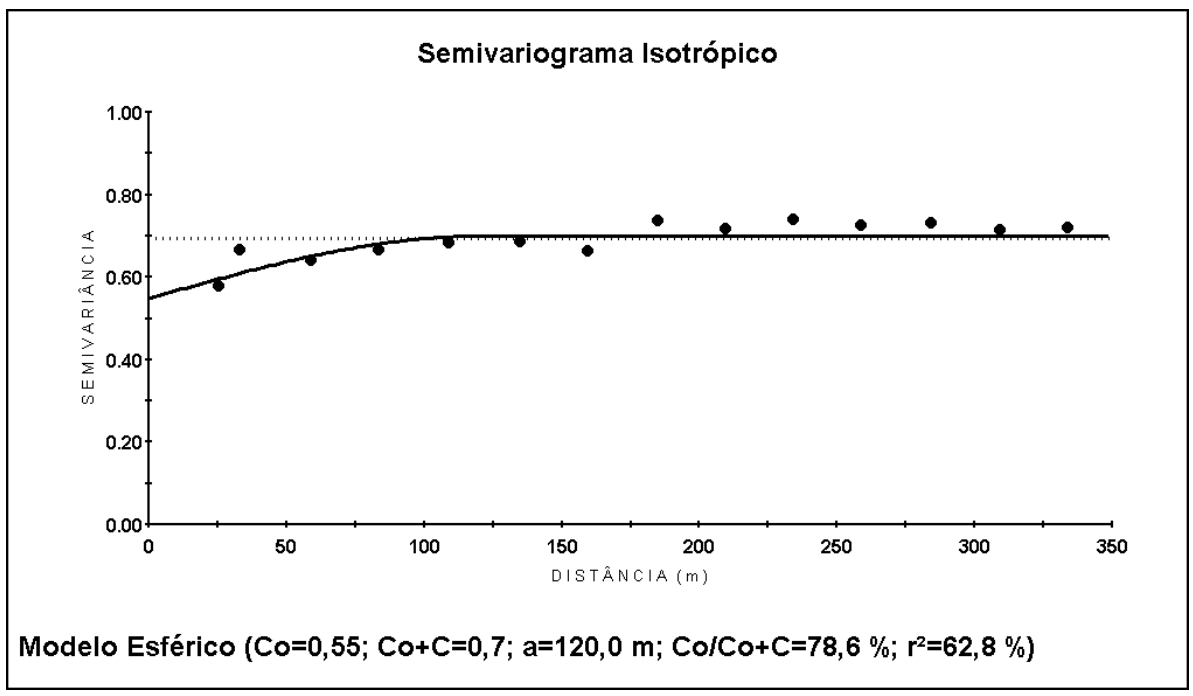

Figura 36 - Semivariograma da variável alumínio (Al) e a representação do resultado da análise geoestatística

Teor de Al (mmolc.dm-3)

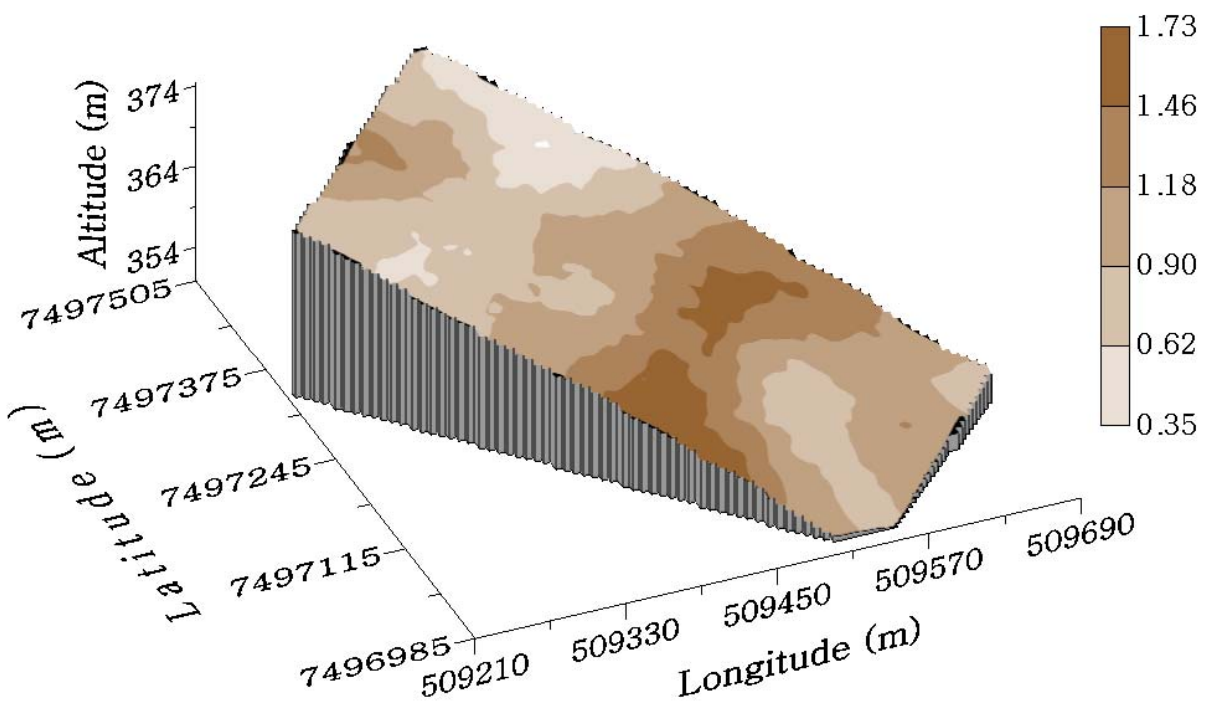

Figura 37 - Ilustração da Interpolação por krigagem da variável alumínio (Al) e a sobreposição (“overlay”) com a altitude da área experimental 


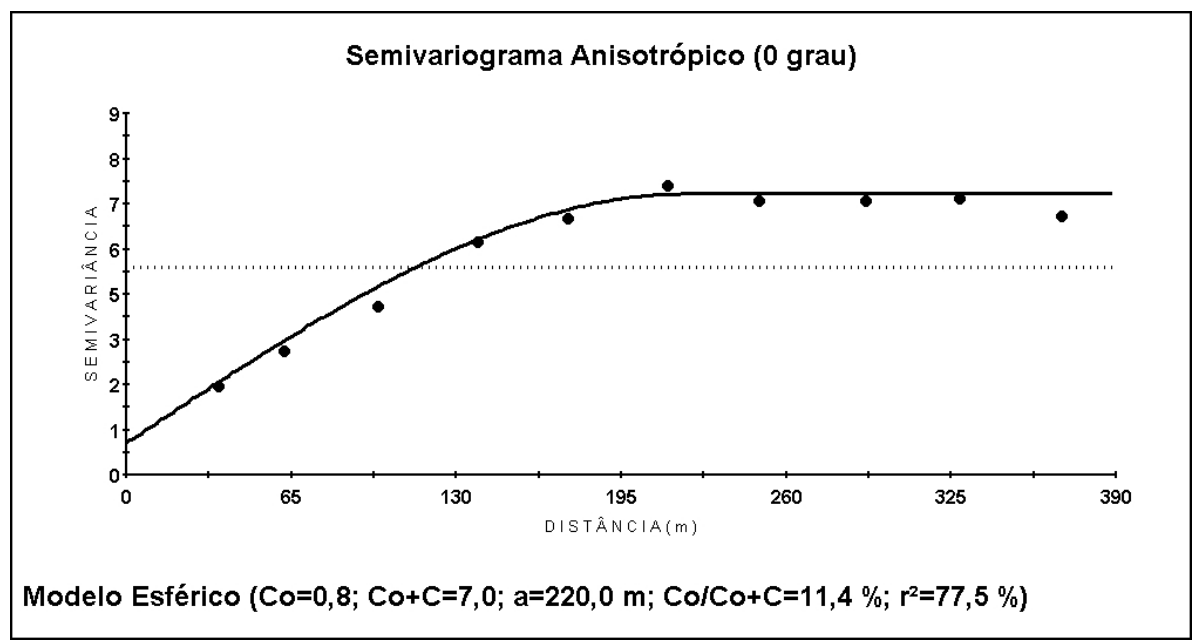

Figura 38 - Semivariograma da variável matéria orgânica (M.O.) e a representação do resultado da análise geoestatística

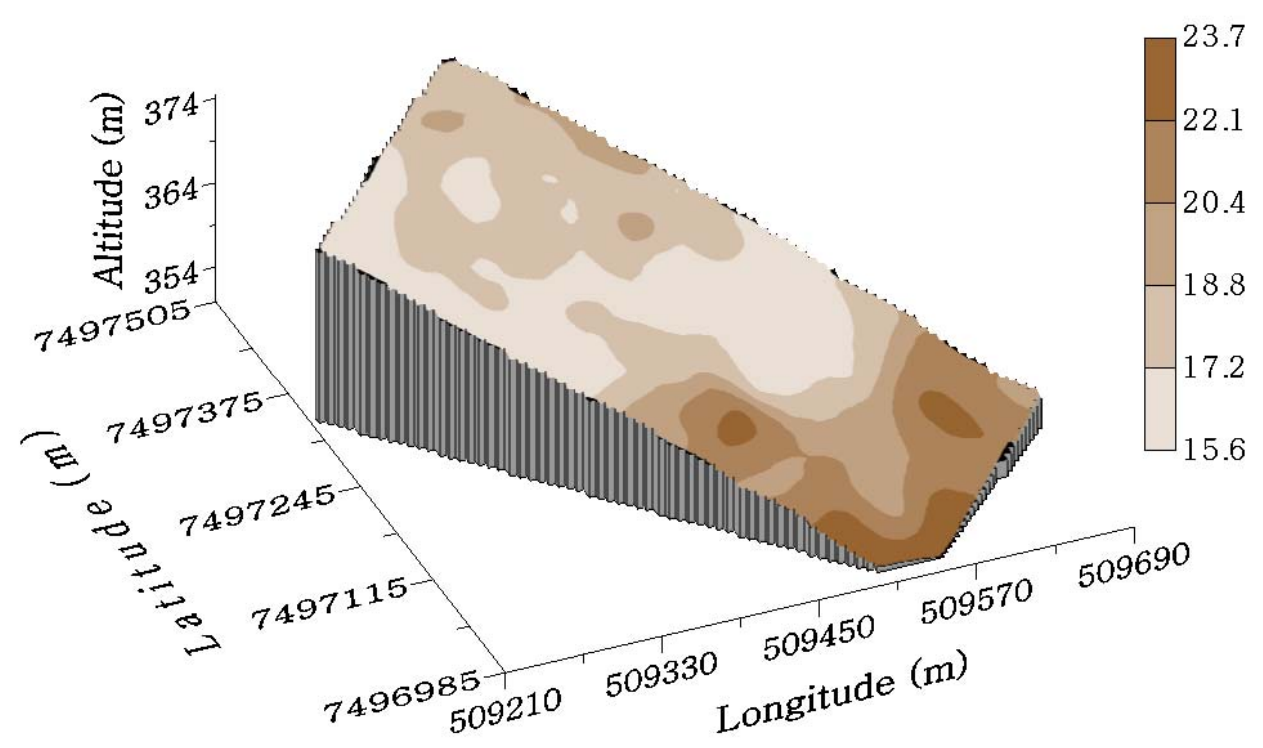

Figura 39 - Ilustração da Interpolação por krigagem da variável matéria orgânica (M.O.) e a sobreposição (“overlay”) com a altitude da área experimental 


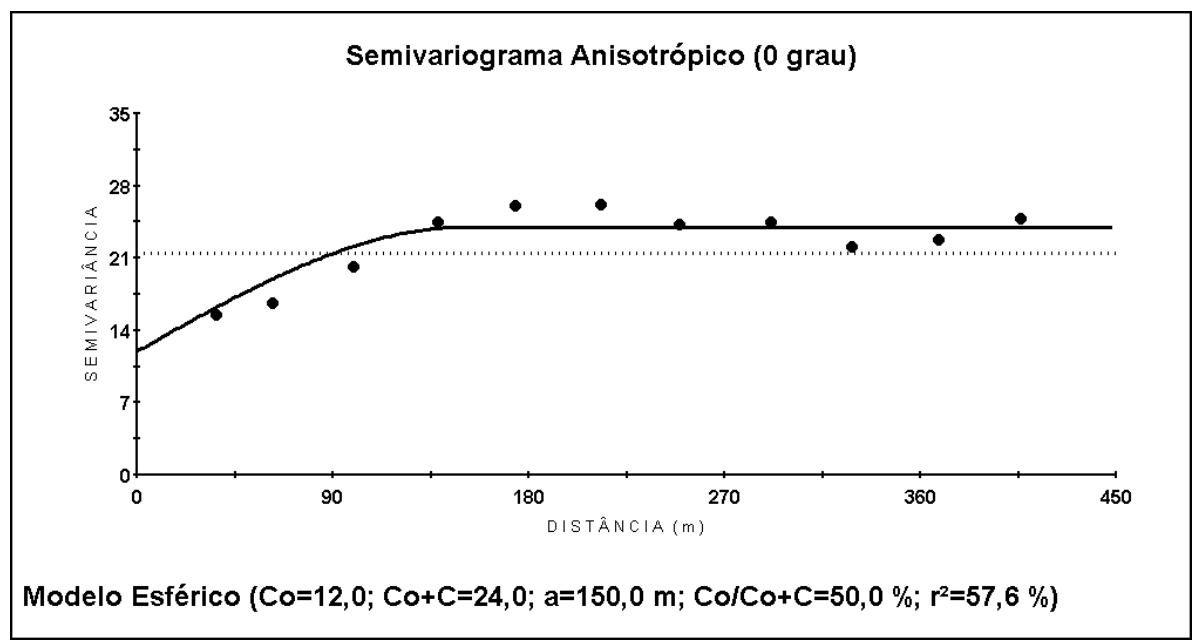

Figura 40 - Semivariograma da variável cálcio $(\mathrm{Ca})$ e a representação do resultado da análise geoestatística

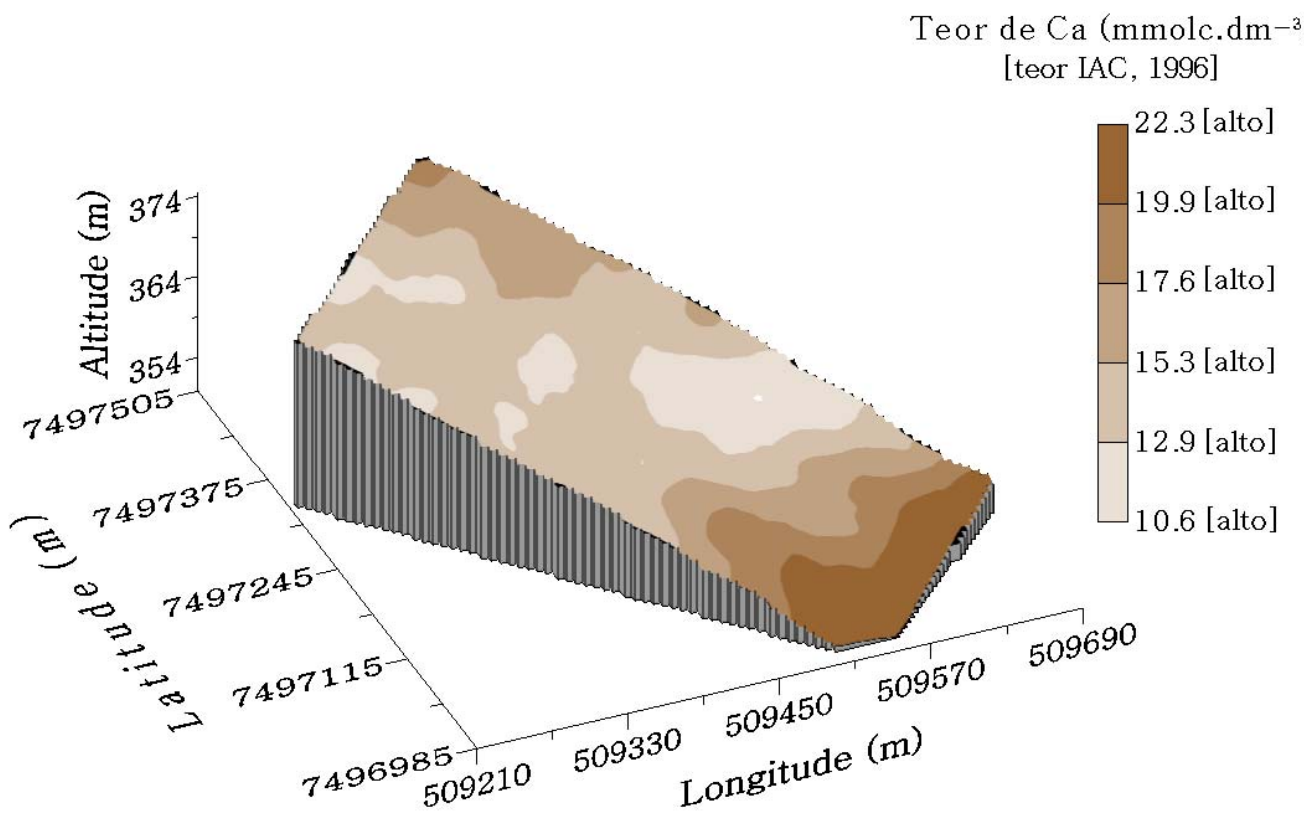

Figura 41 - Ilustração da Interpolação por krigagem da variável cálcio $(\mathrm{Ca})$ e a sobreposição (“overlay”) com a altitude da área experimental 




Figura 42 - Semivariograma da variável magnésio $(\mathrm{Mg})$ e a representação do resultado da análise geoestatística

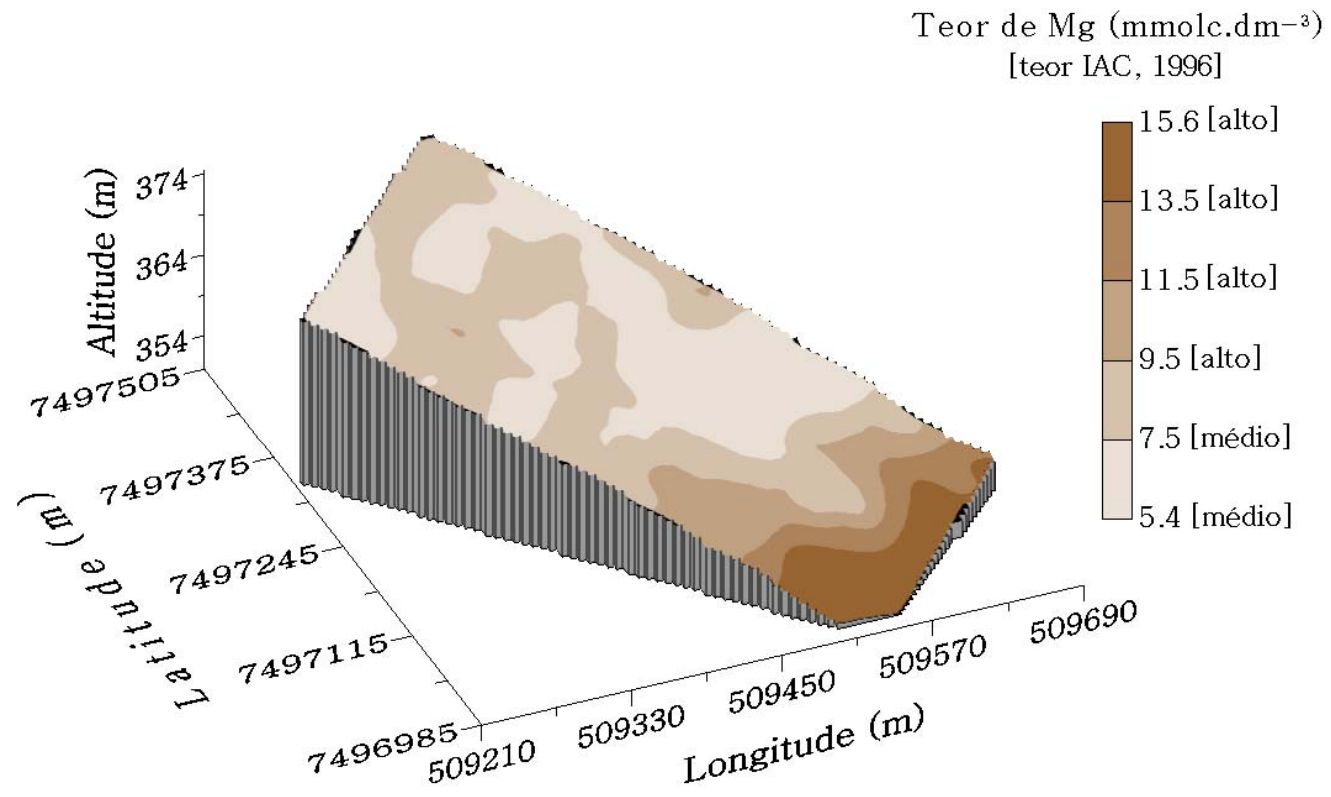

Figura 43 - Ilustração da Interpolação por krigagem da variável magnésio $(\mathrm{Mg})$ e a sobreposição (“overlay”) com a altitude da área experimental 


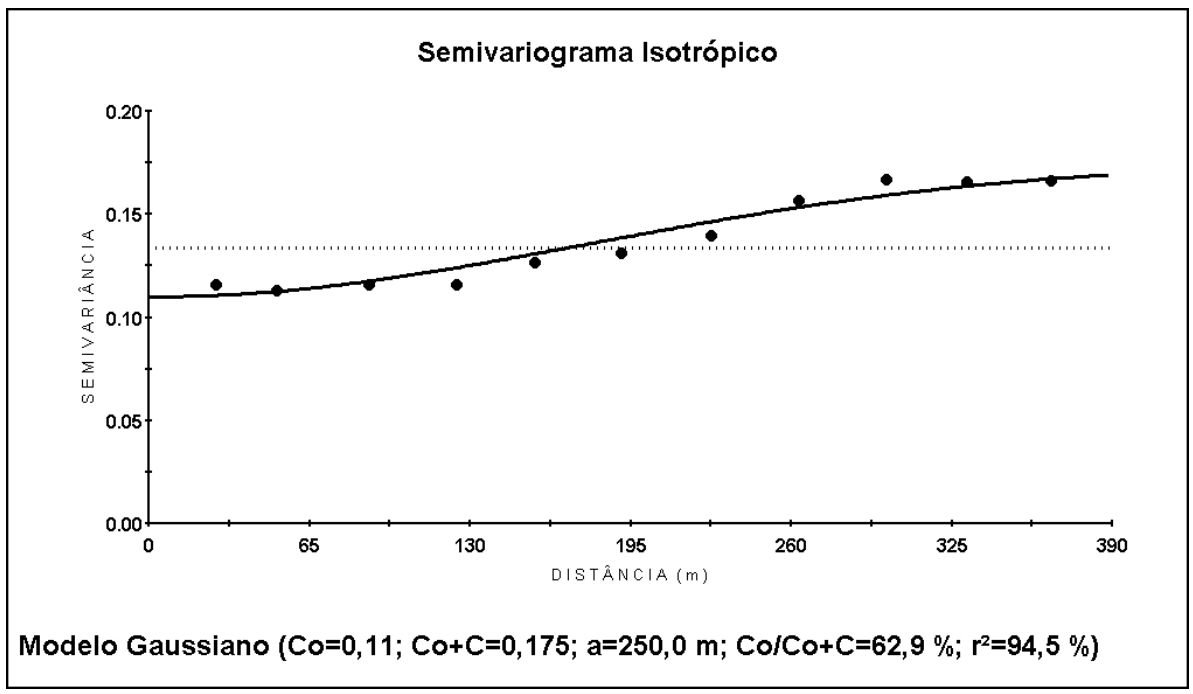

Figura 44 - Semivariograma da variável potássio $(K)$ e a representação do resultado da análise geoestatística

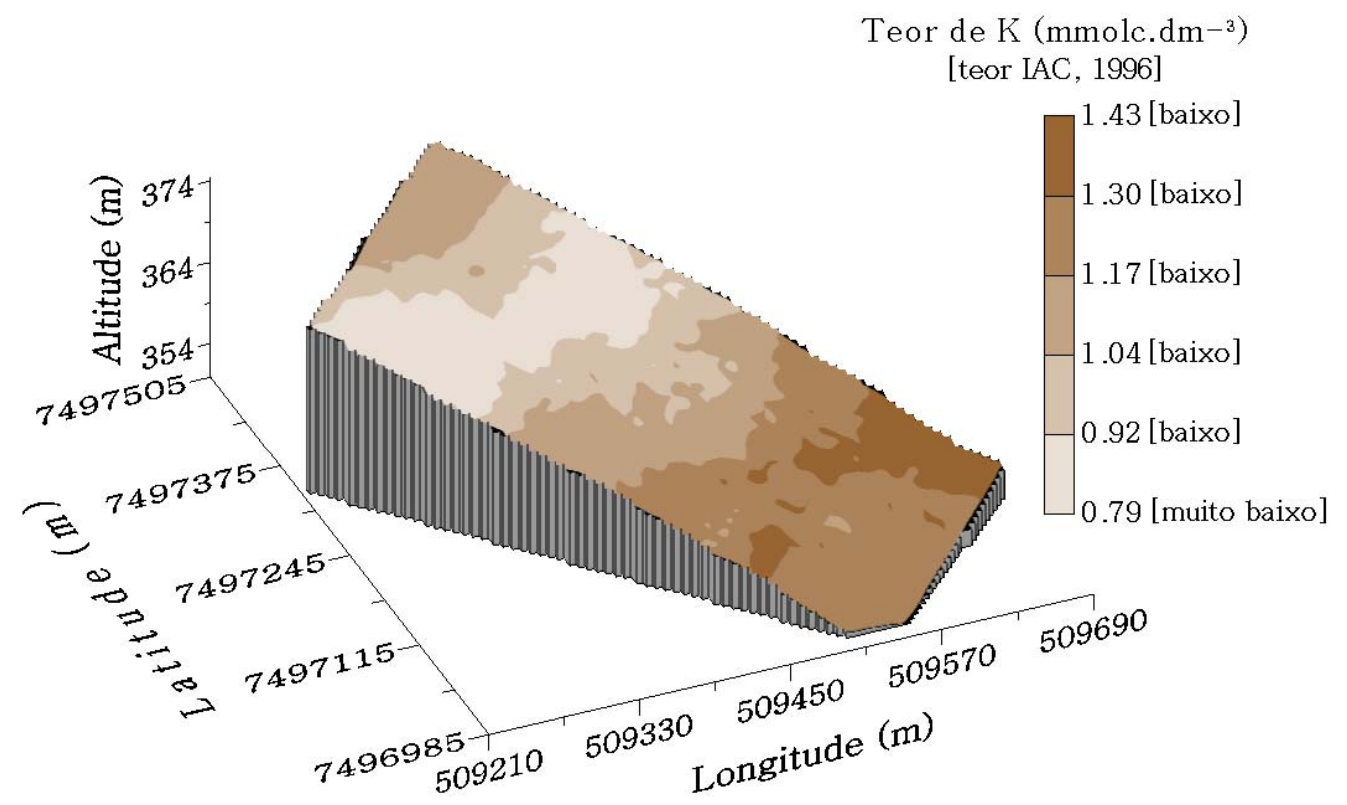

Figura 45 - Ilustração da Interpolação por krigagem da variável potássio (K) e a sobreposição (“overlay”) com a altitude da área experimental 


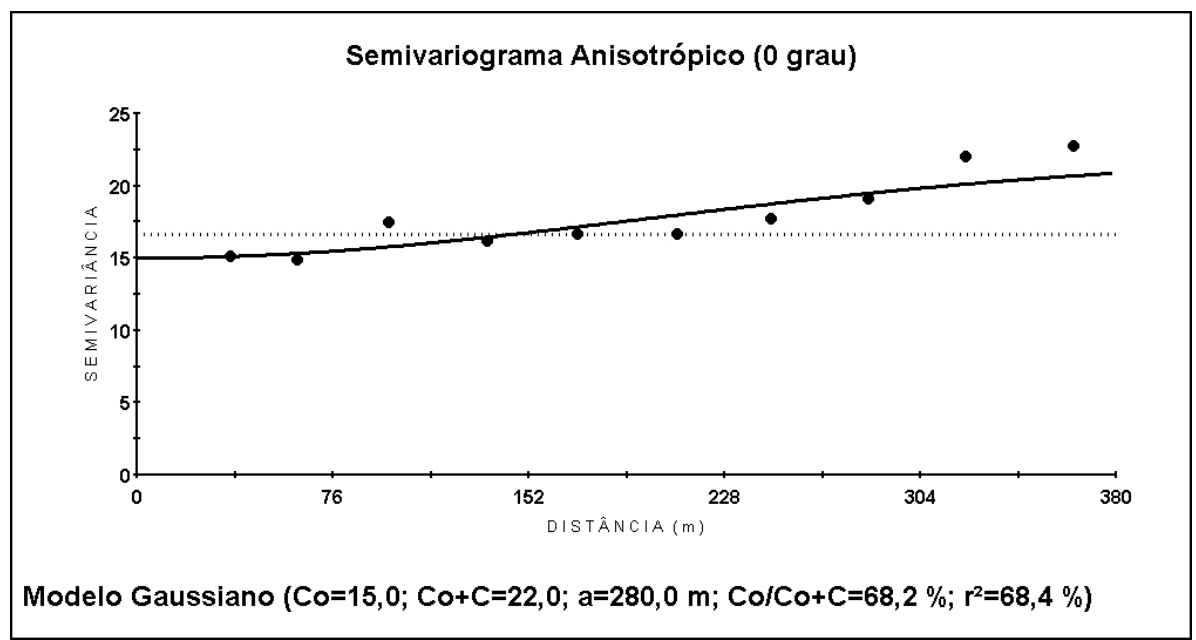

Figura 46 - Semivariograma da variável fósforo $(\mathrm{P})$ e a representação do resultado da análise geoestatística

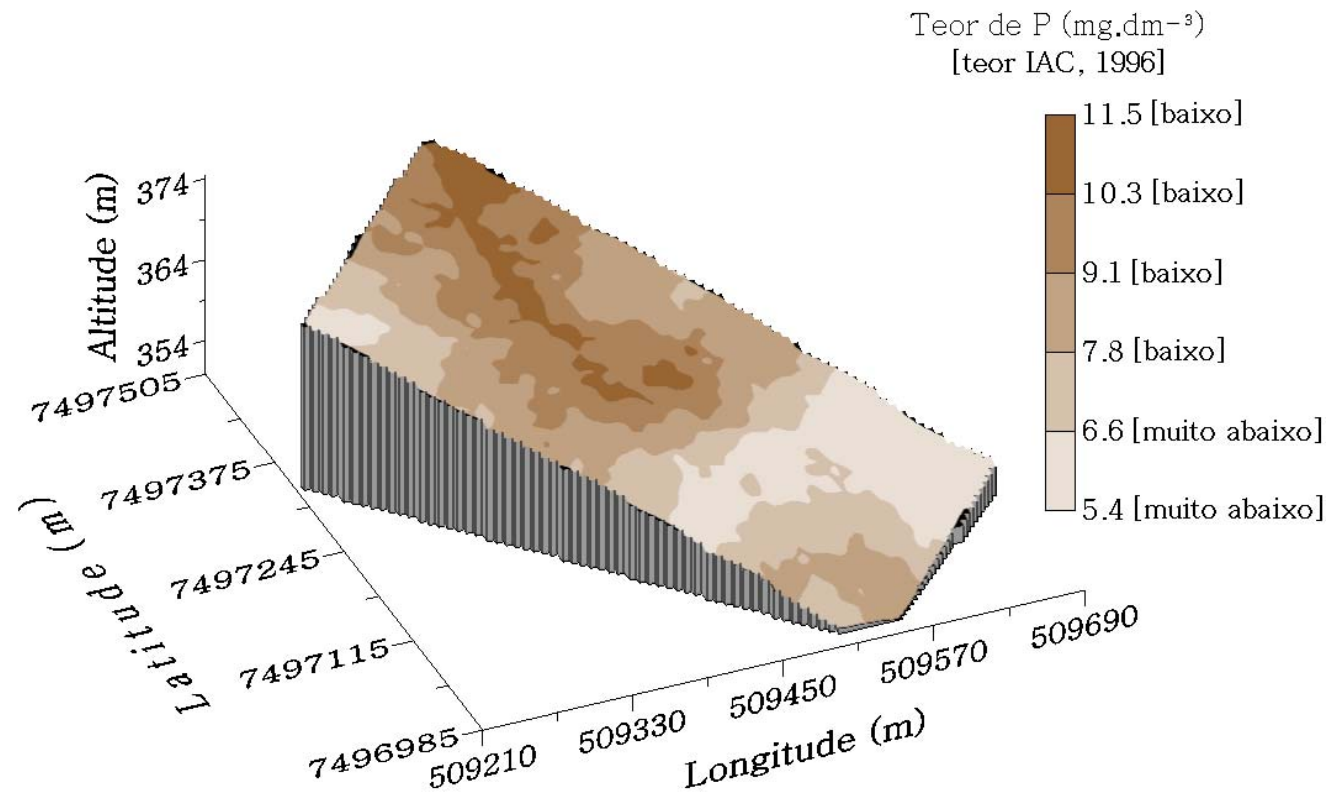

Figura 47 - Ilustração da Interpolação por krigagem da variável fósforo $(\mathrm{P})$ e a sobreposição (“overlay”) com a altitude da área experimental 


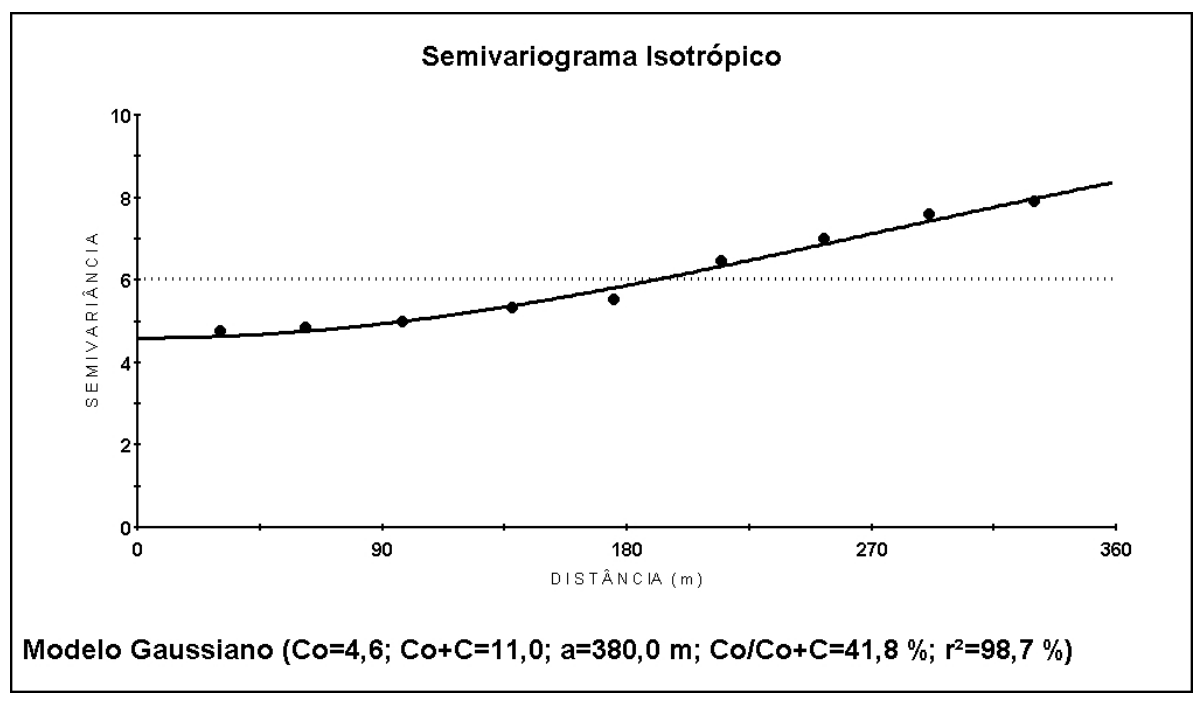

Figura 48 - Semivariograma da variável enxofre (S) e a representação do resultado da análise geoestatística

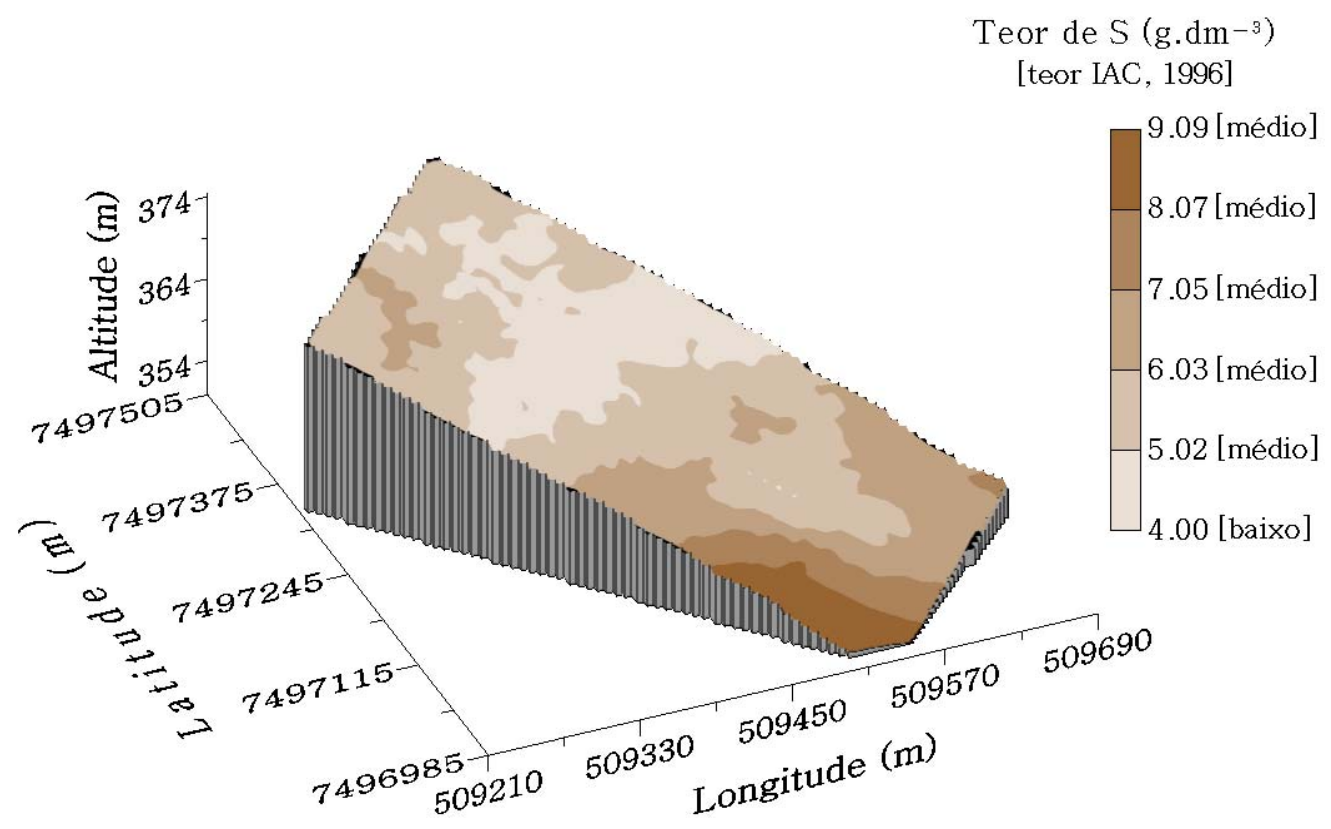

Figura 49 - Ilustração da Interpolação por krigagem da variável enxofre (S) e a sobreposição ("overlay”) com a altitude da área experimental 


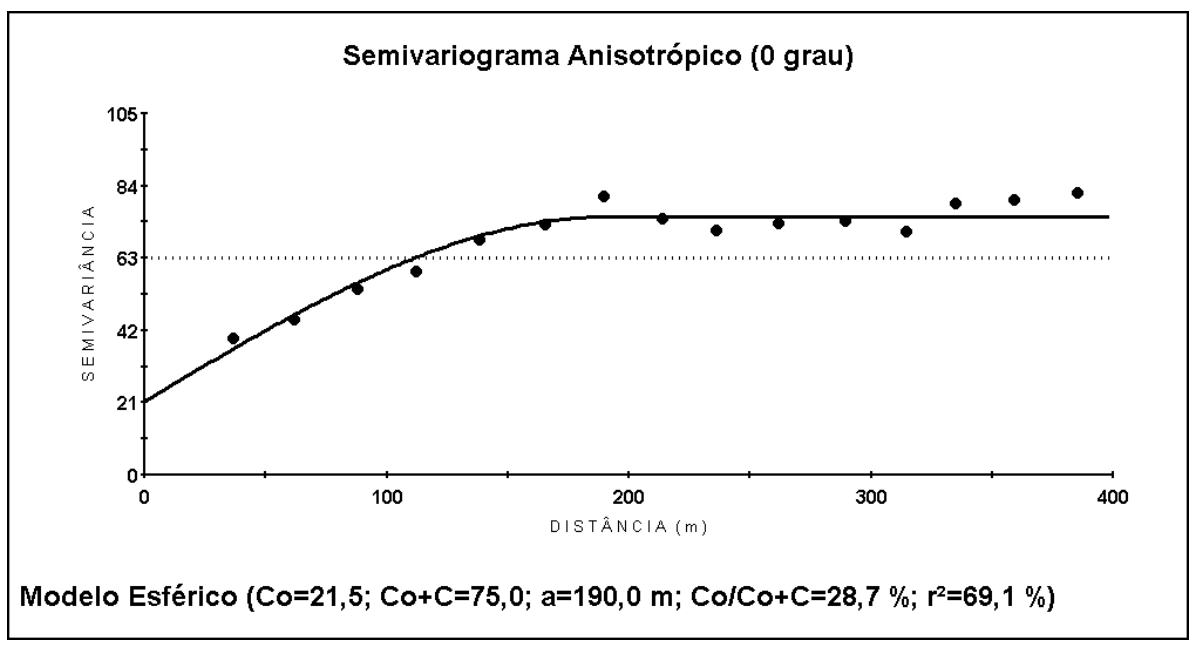

Figura 50 - Semivariograma da variável soma de bases (SB) e a representação do resultado da análise geoestatística

SB (mmolc. dm-3)

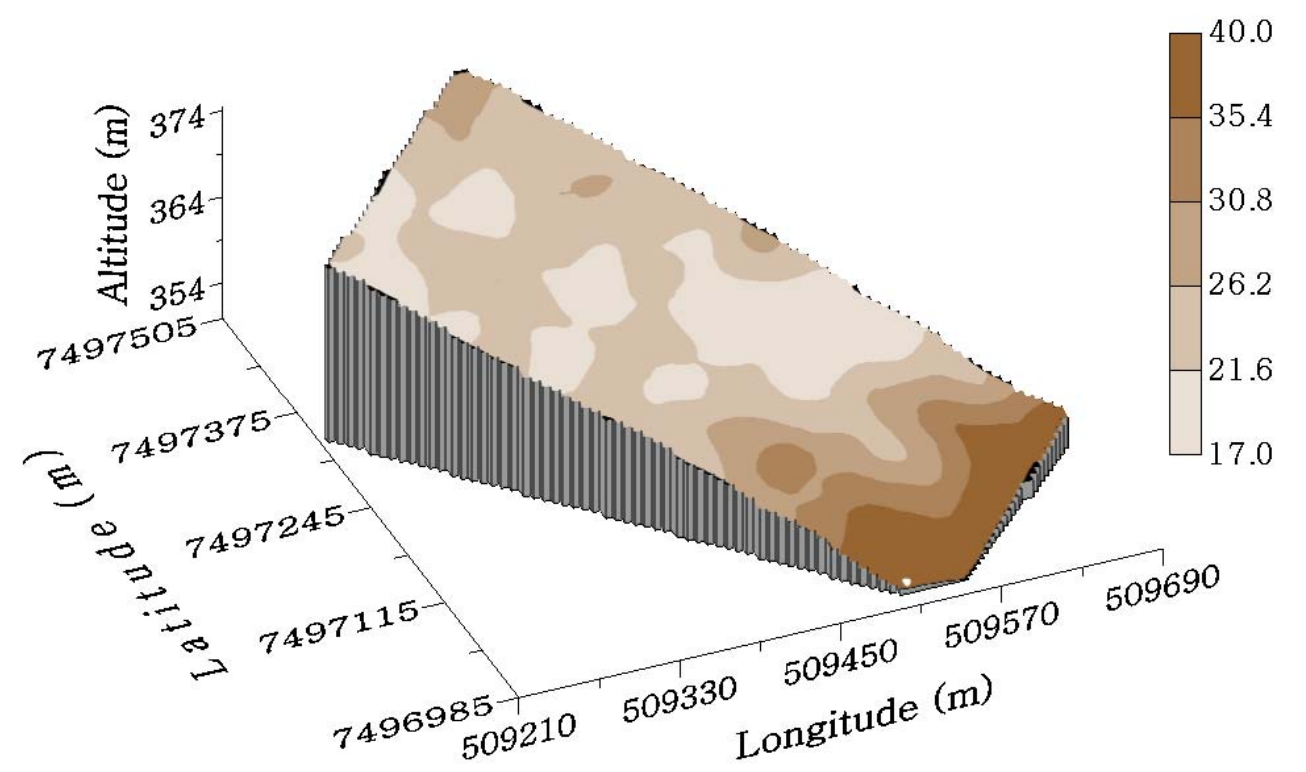

Figura 51 - Ilustração da Interpolação por krigagem da variável soma de bases (SB) e a sobreposição (“overlay”) com a altitude da área experimental 


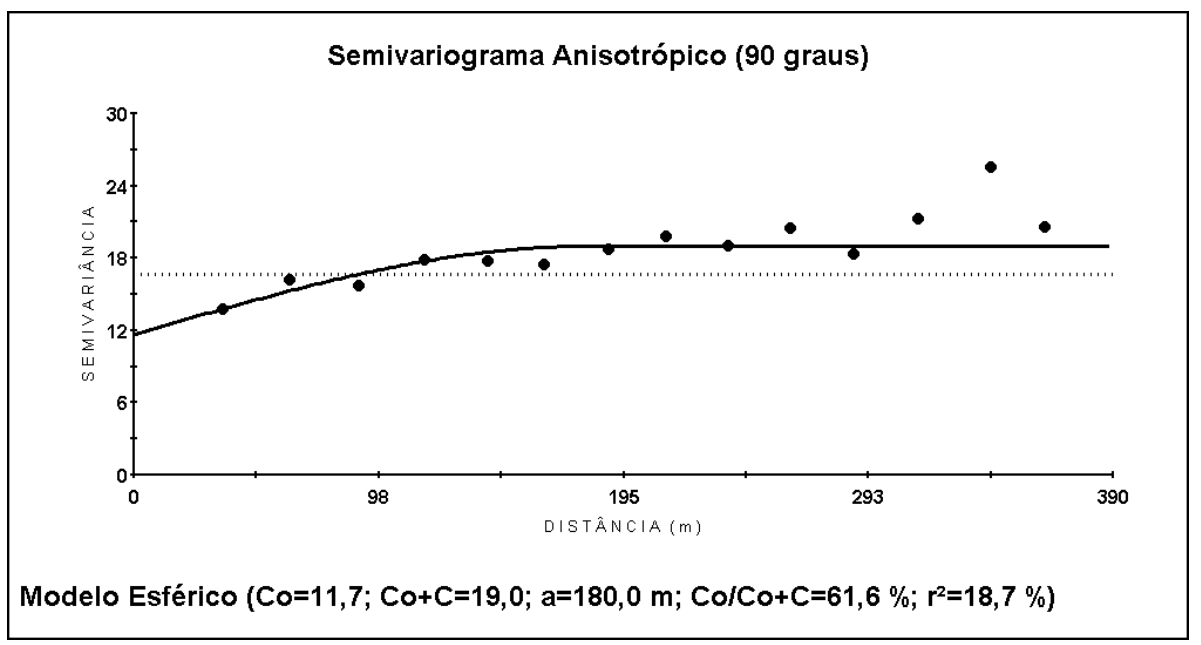

Figura 52 - Semivariograma da variável porcentagem de saturação por alumínio (m\%) e a representação do resultado da análise geoestatística

m (\%)

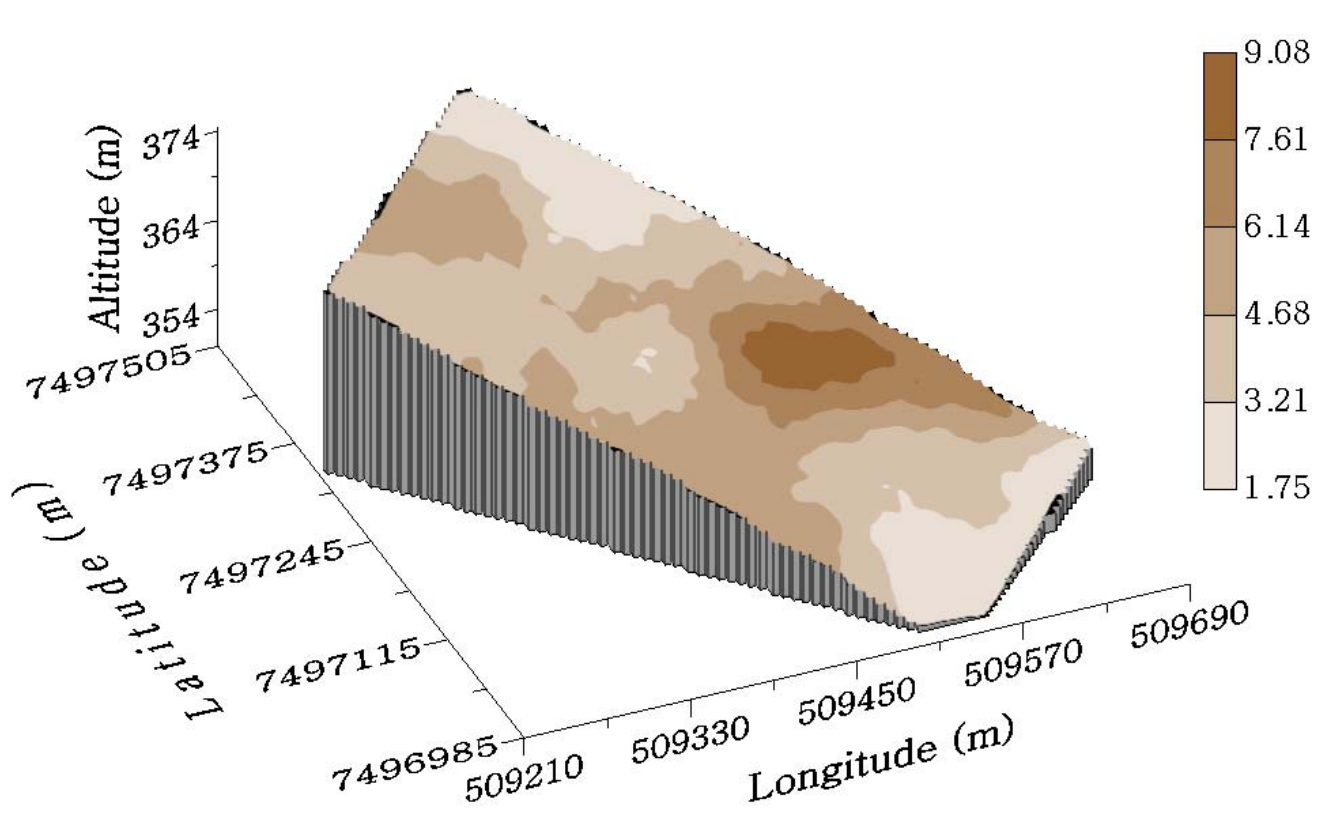

Figura 53 - Ilustração da Interpolação por krigagem da variável porcentagem de saturação por alumínio (m\%) e a sobreposição ("overlay”) com a altitude da área experimental 


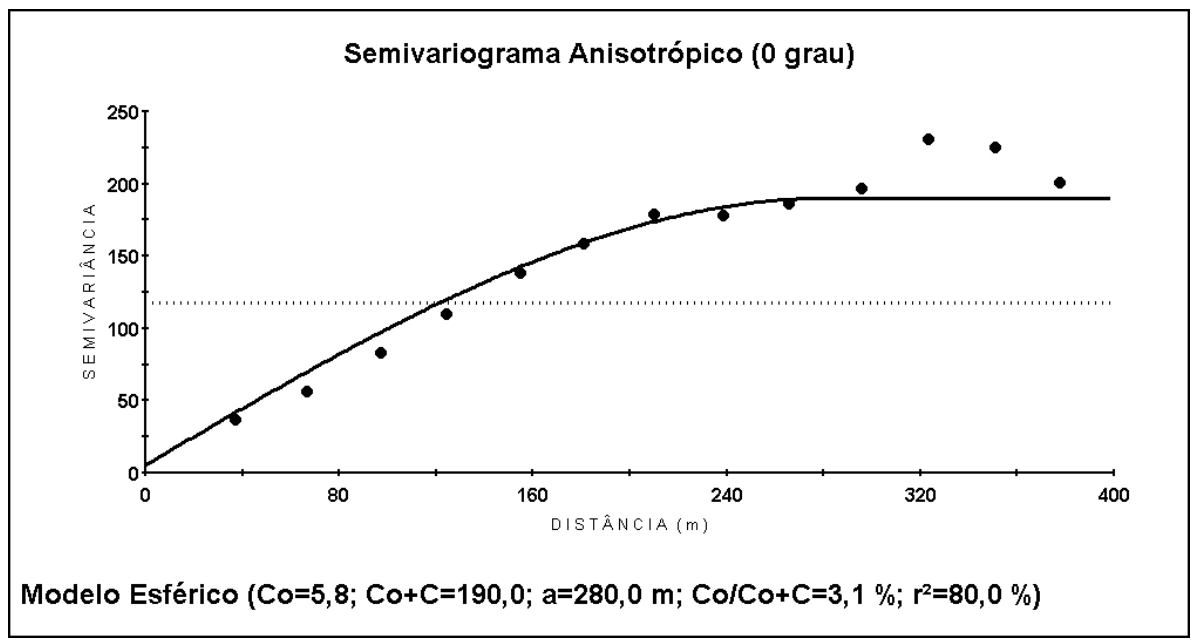

Figura 54 - Semivariograma da variável capacidade de troca de cátions (CTC) e a representação do resultado da análise geoestatística

CTC (mmolc. dm-3)

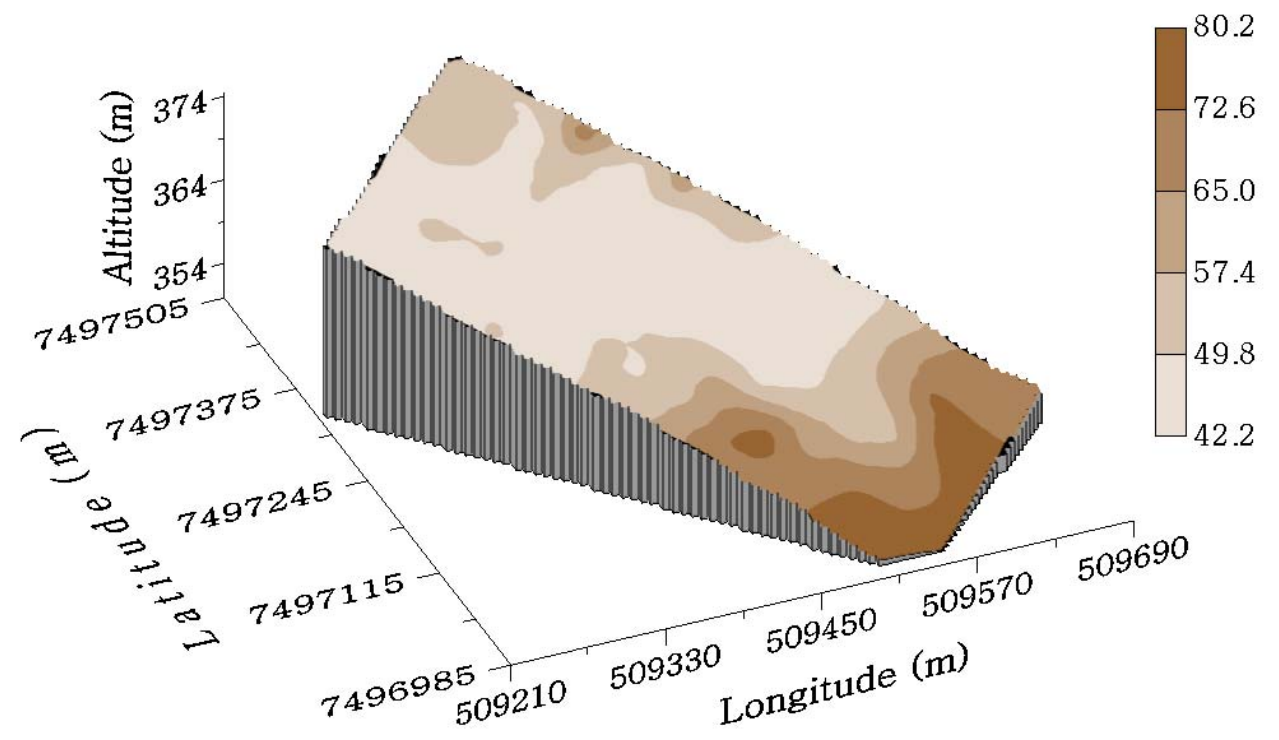

Figura 55 - Ilustração da Interpolação por krigagem da variável capacidade de troca de cátions (CTC) e a sobreposição (“overlay”) com a altitude da área experimental 


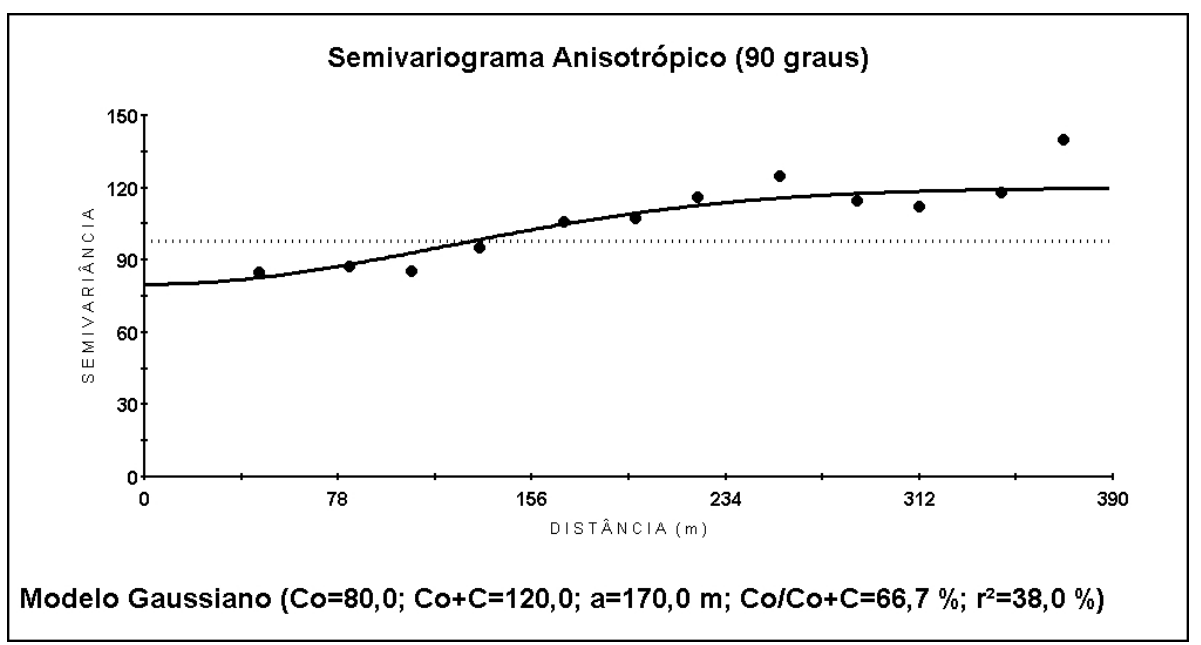

Figura 56 - Semivariograma da variável porcentagem de saturação por bases (V\%) e a representação do resultado da análise geoestatística

$\mathrm{V}(\%)$

[teor IAC, 1996]

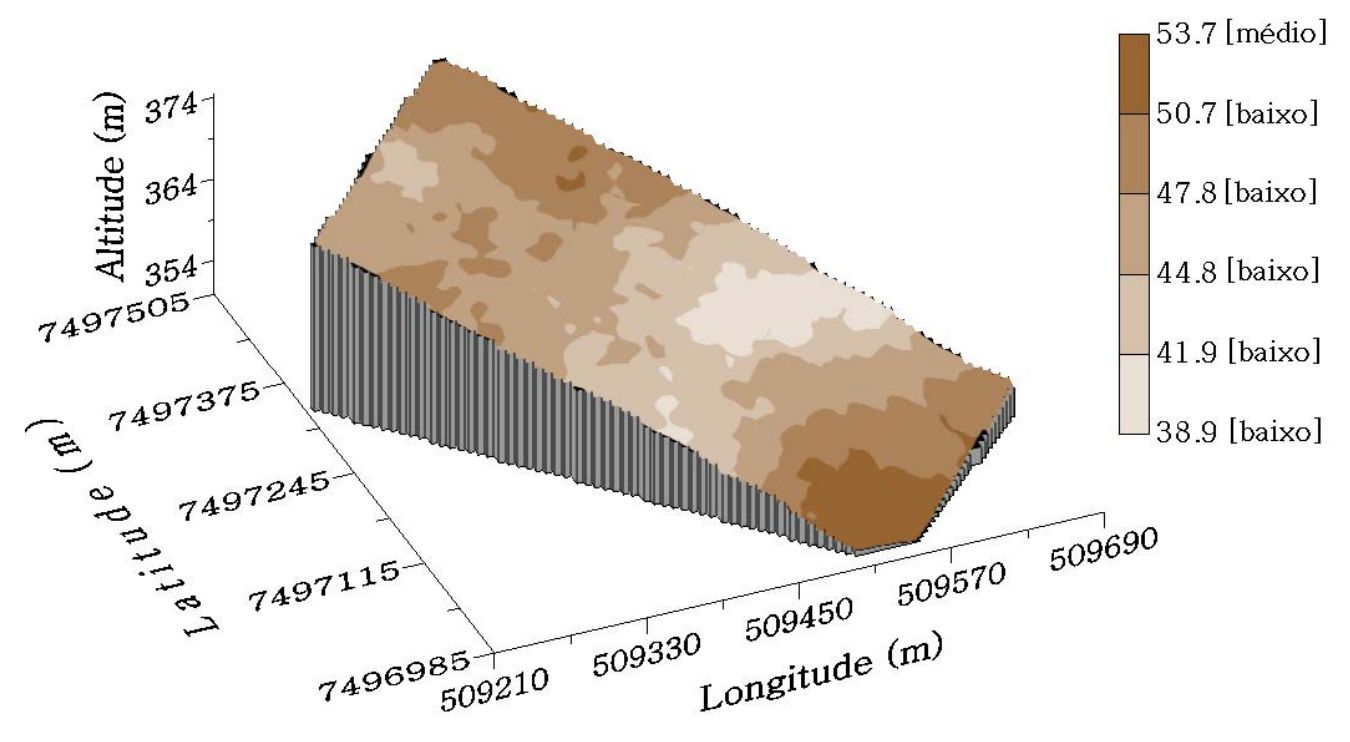

Figura 57 - Ilustração da Interpolação por krigagem da variável porcentagem de saturação por bases (V\%) e a sobreposição (“overlay”) com a altitude da área experimental 


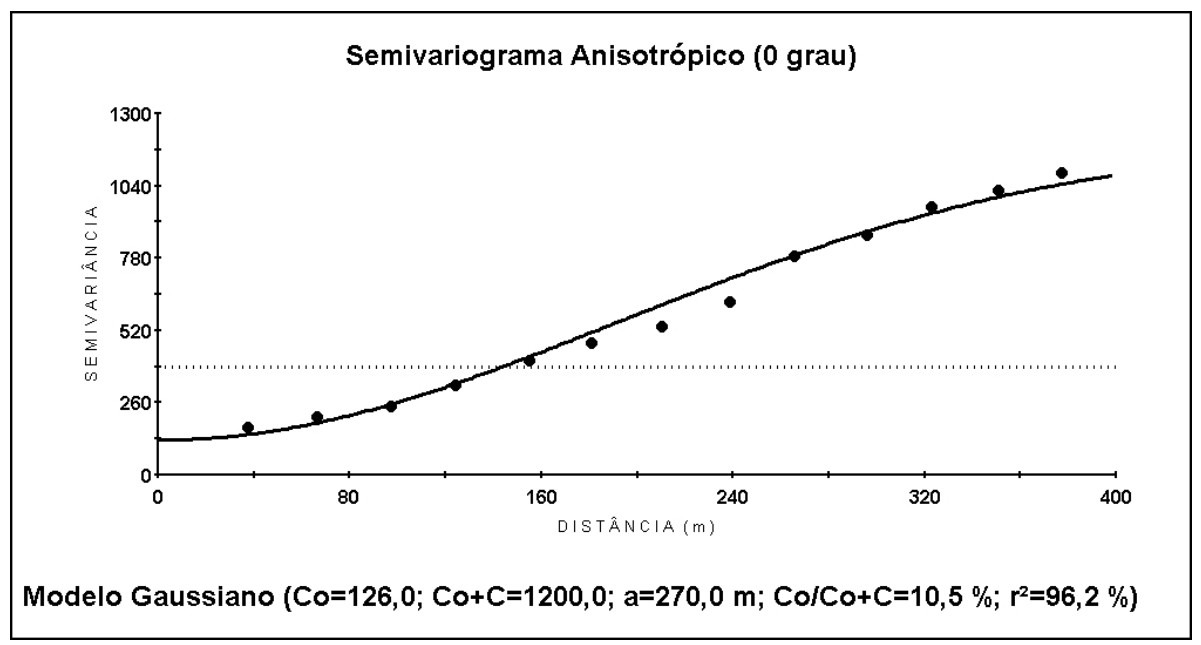

Figura 58 - Semivariograma da variável manganês (Mn) e a representação do resultado da análise geoestatística

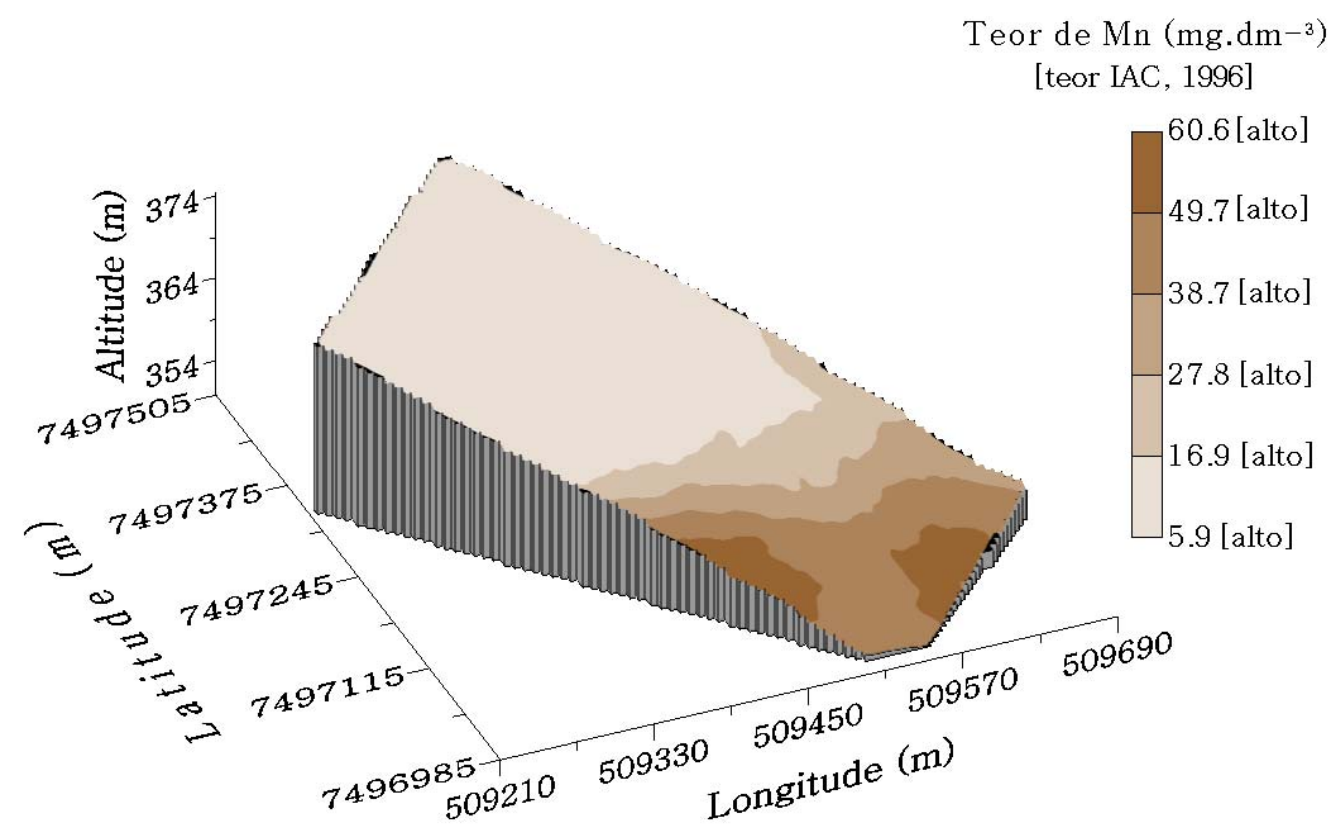

Figura 59 - Ilustração da Interpolação por krigagem da variável manganês (Mn) e a sobreposição (“overlay”) com a altitude da área experimental 


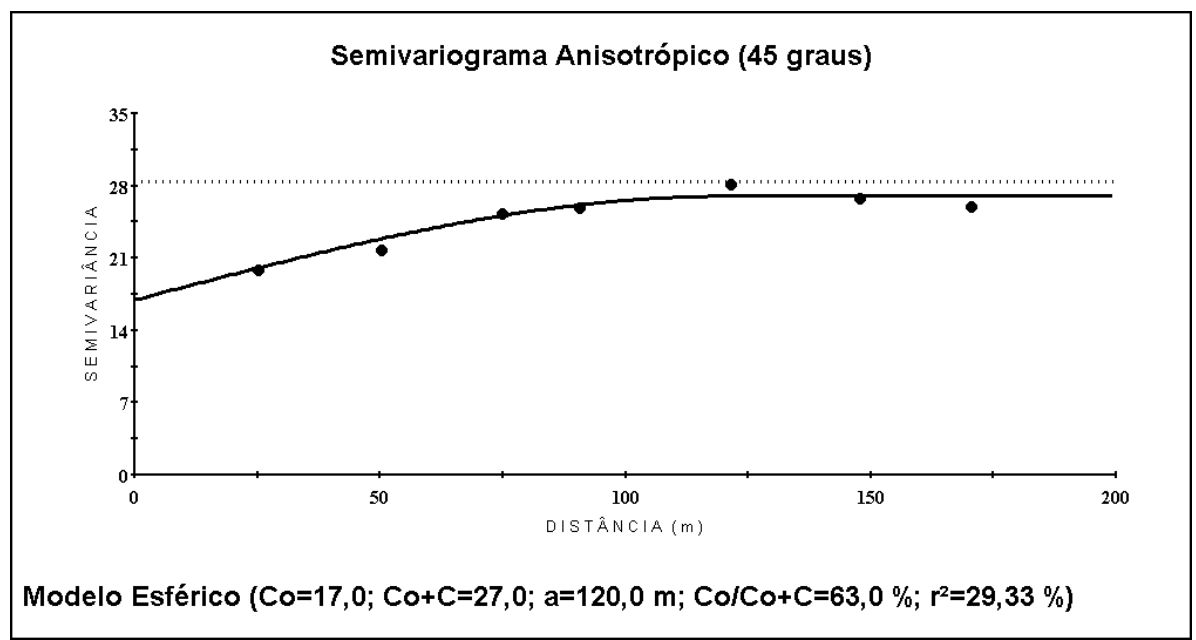

Figura 60 - Semivariograma da variável ferro $(\mathrm{Fe})$ e a representação do resultado da análise geoestatística

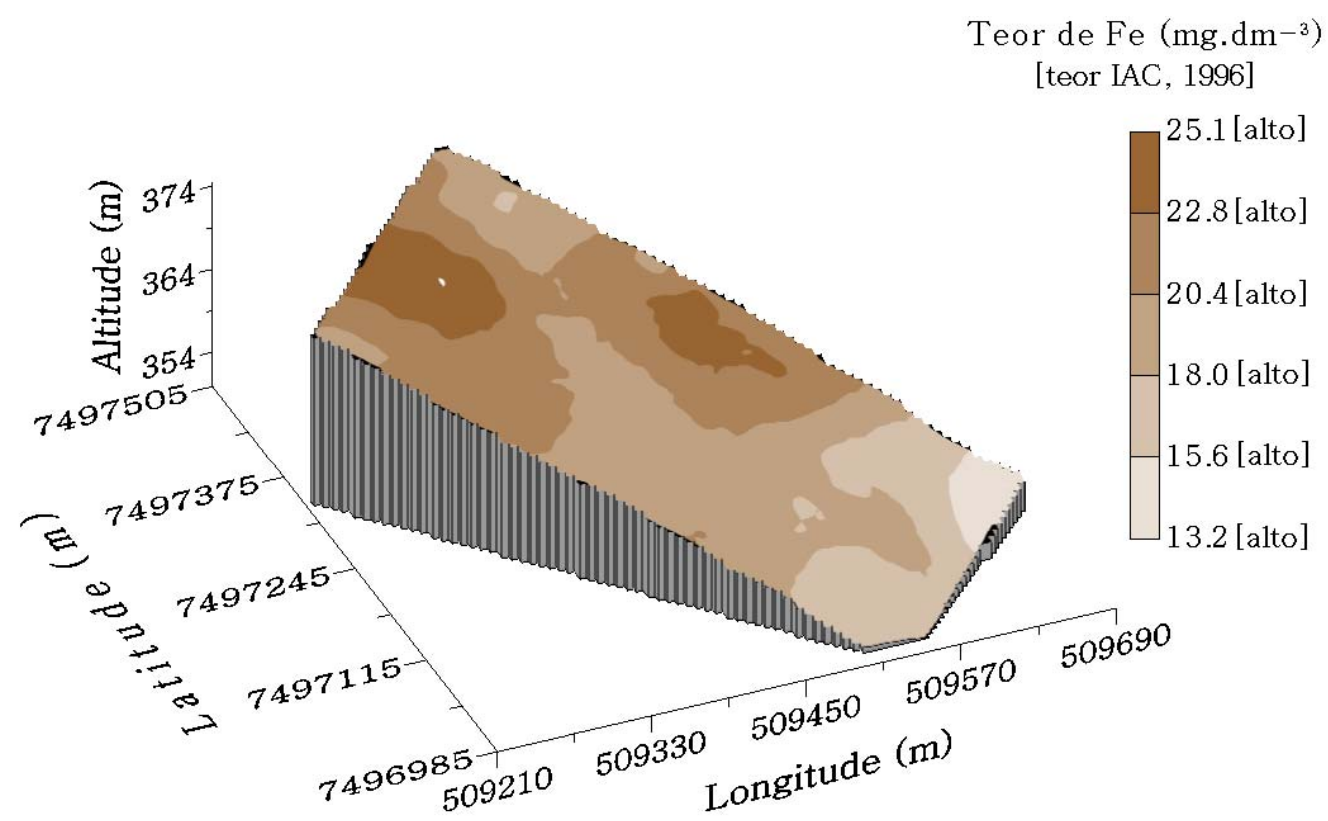

Figura 61 - Ilustração da Interpolação por krigagem da variável ferro (Fe) e a sobreposição (“overlay”) com a altitude da área experimental 


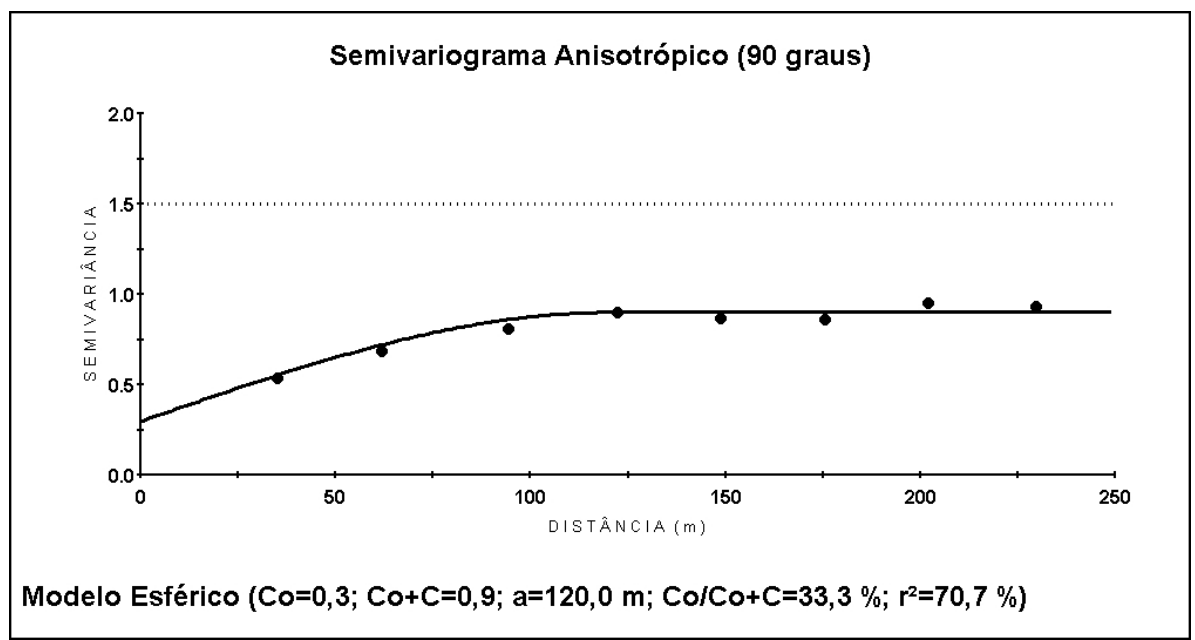

Figura 62 - Semivariograma da variável cobre $(\mathrm{Cu})$ e a representação do resultado da análise geoestatística

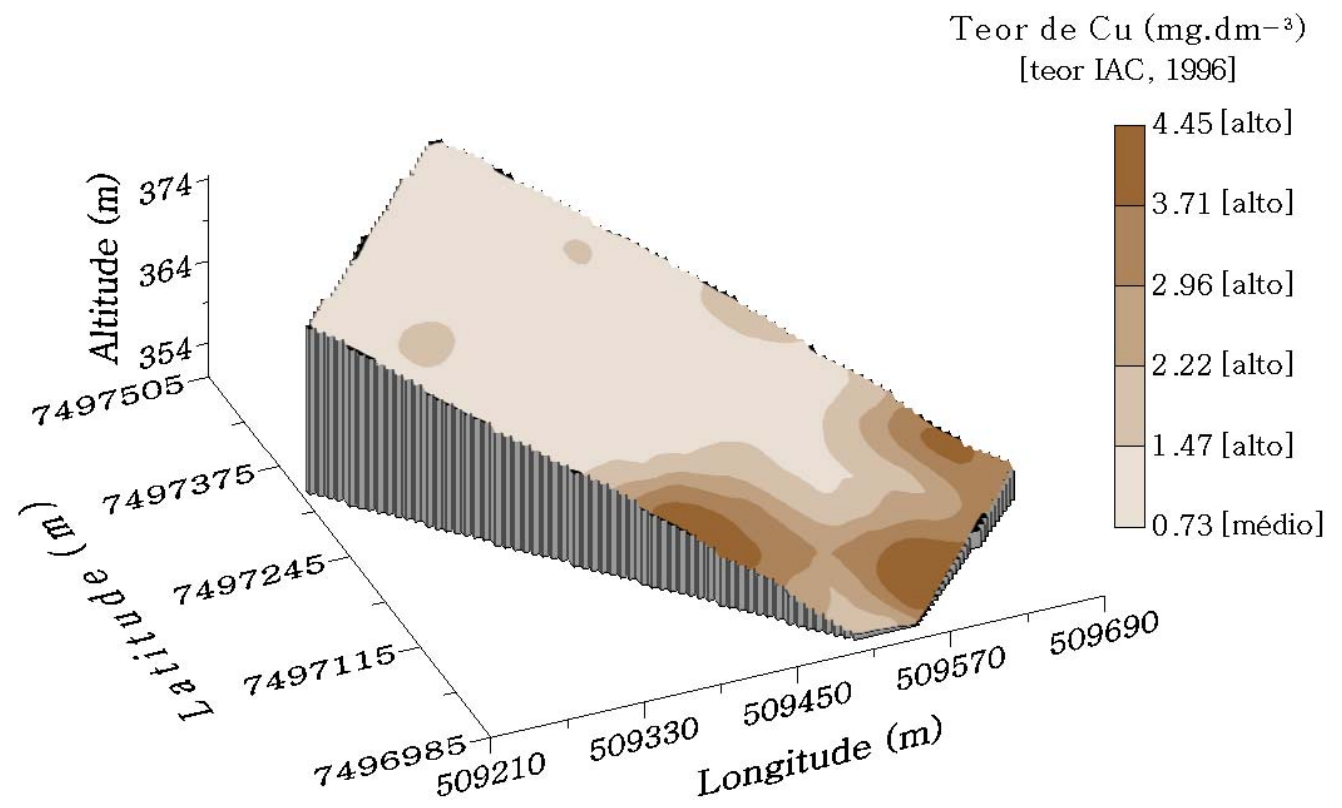

Figura 63 - Ilustração da Interpolação por krigagem da variável cobre $(\mathrm{Cu})$ e a sobreposição (“overlay”) com a altitude da área experimental 


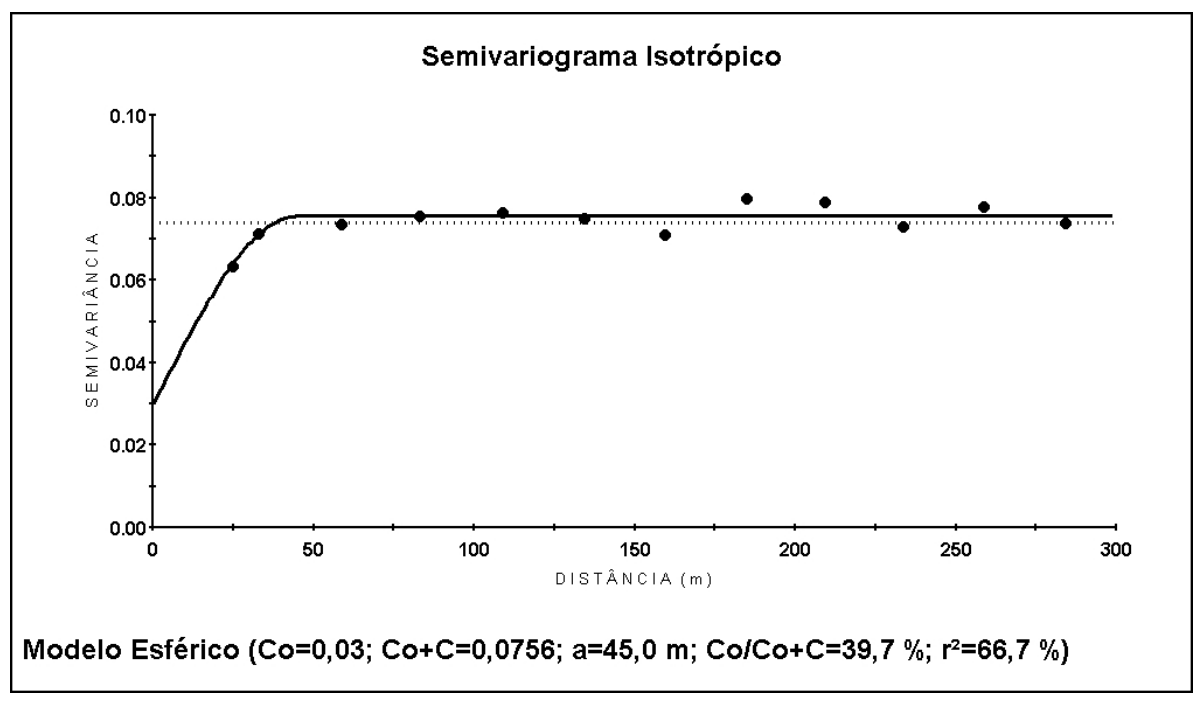

Figura 64 - Semivariograma da variável zinco $(\mathrm{Zn})$ e a representação do resultado da análise geoestatística

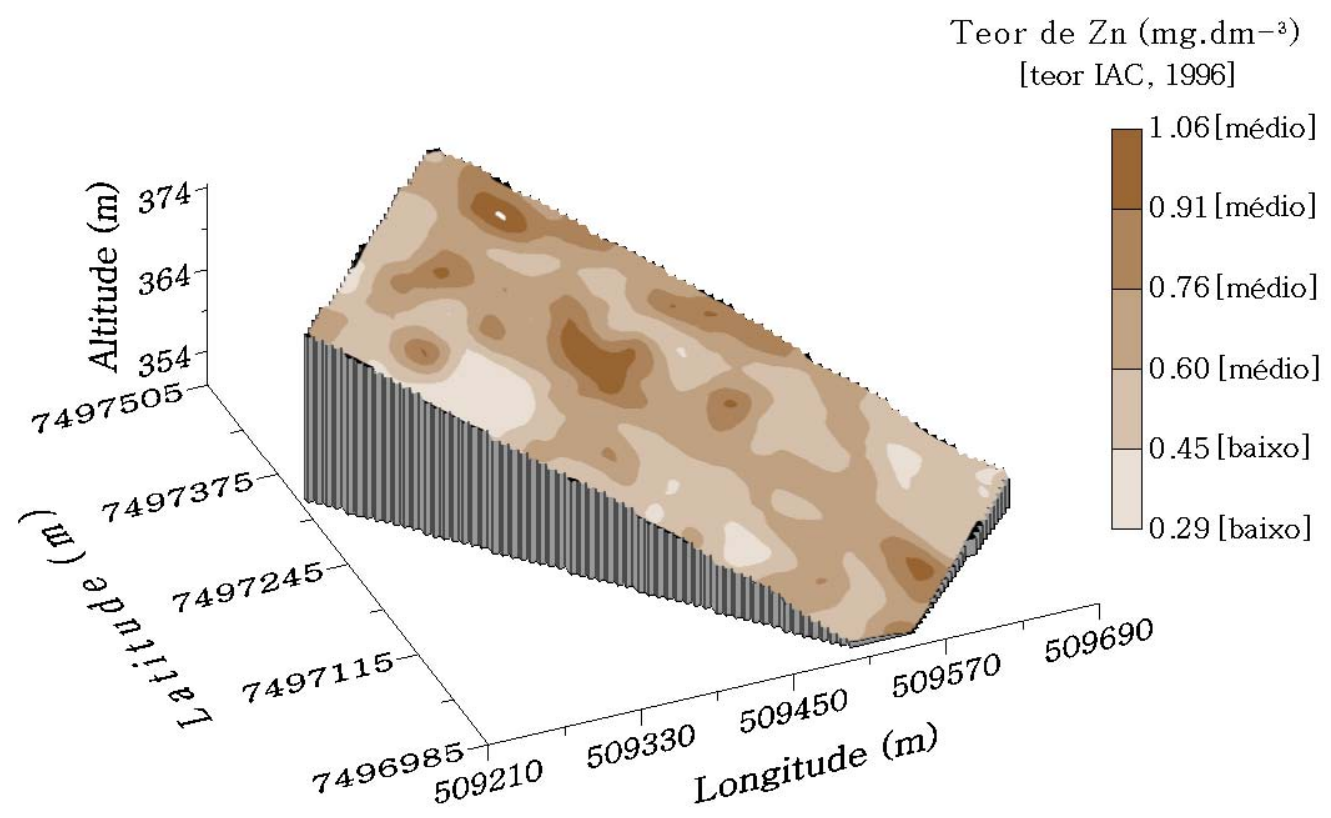

Figura 65 - Ilustração da Interpolação por krigagem da variável zinco (Zn) e a sobreposição (“overlay”) com a altitude da área experimental 


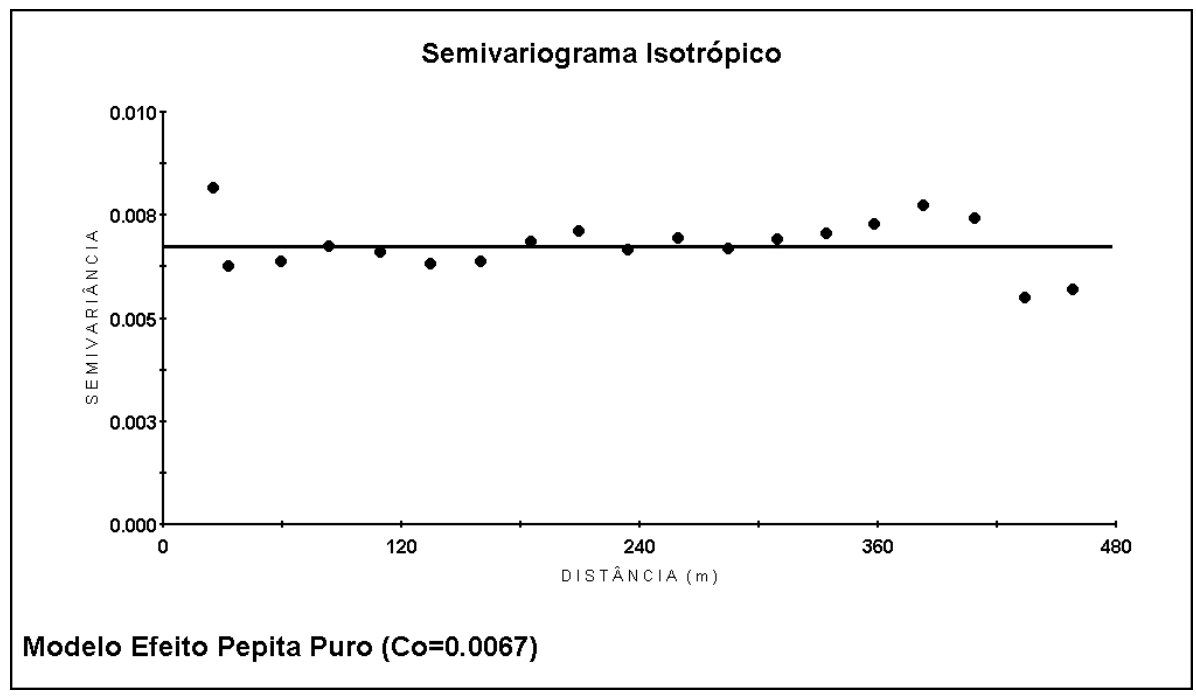

Figura 66 - Semivariograma da variável boro (B) e a representação do resultado da análise geoestatística

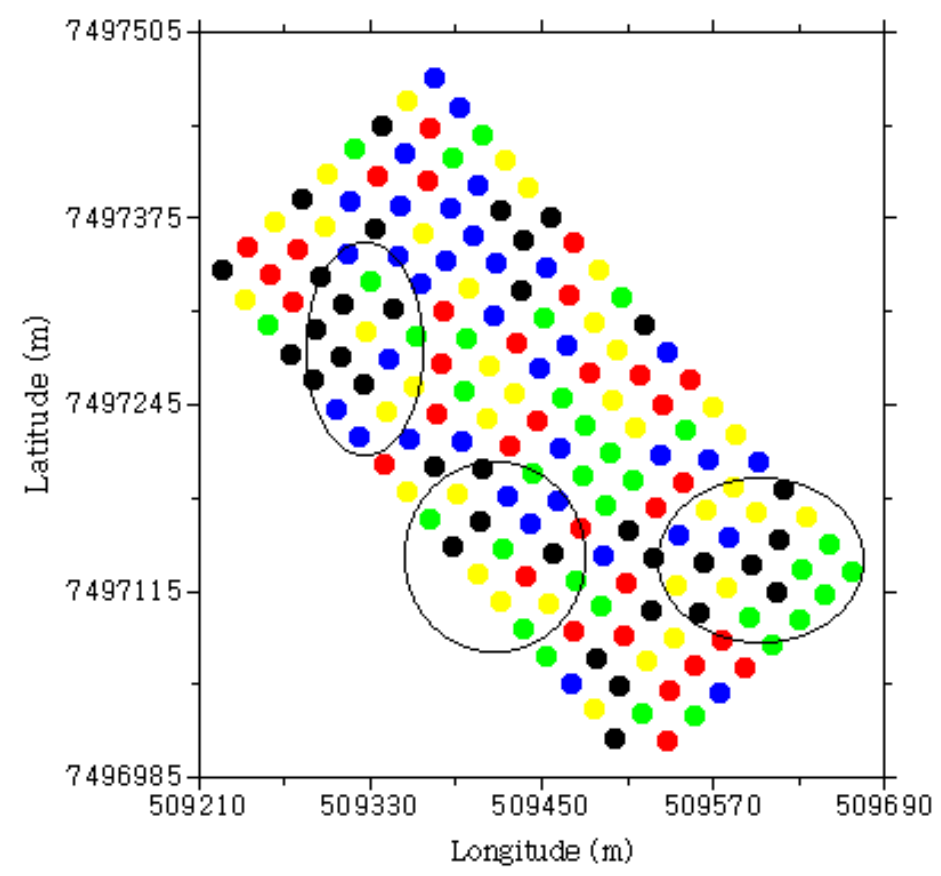

Teor de B (mg.dm-3)

- 0.31 a 0.42

0.26 a 0.31

0.20 a 0.26

0.14 a 0.20

0.12 a 0.14

Figura 67 - Ilustração do mapa de variabilidade espacial (“Classed post - Equal number”) da variável boro (B) com áreas circundadas mostrando valores extremos muito próximos, o que acabou contribuindo para causar a independência espacial 
No Quadro 1, pode-se verificar os valores limites de alguns (12) atributos estabelecidos por alguns Laboratórios de Análises Químicas.

\begin{tabular}{|lccccc|}
\hline Variáveis & Muito Baixo & Baixo & Médio & Alto & Muito Alto \\
\hline $\mathrm{pH} \mathrm{CaCl}$ & & $5,6-6,0$ & $5,1-5,5$ & $4,4-5,0$ & Até 4,3 \\
$\mathrm{Ca}\left(\mathrm{mmolc}_{\mathrm{dm}} \mathrm{dm}^{-3}\right)$ & $>6,0$ & $0-3$ & $4-7$ & $>7$ & \\
$\mathrm{Mg}\left(\mathrm{mmolc} \cdot \mathrm{dm}^{-3}\right)$ & & $0-4$ & $5-8$ & $>8$ & \\
$\mathrm{~K}\left(\mathrm{mmolc} \cdot \mathrm{dm}^{-3}\right)$ & $0,0-0,7$ & $0,8-1,5$ & $1,6-3,0$ & $3,1-6,0$ & $>6,0$ \\
$\mathrm{P}\left(\mathrm{mg} \cdot \mathrm{dm}^{-3}\right)$ & $0-6$ & $7-15$ & $16-40$ & $41-80$ & $>80$ \\
$\mathrm{~S}\left(\mathrm{mg} \cdot \mathrm{dm}^{-3}\right)$ & & $0-4$ & $5-10$ & $>10$ & \\
$\mathrm{~V}(\%)$ & $26-50$ & $51-70$ & $71-90$ & $>90$ \\
$\mathrm{Mn}\left(\mathrm{mg} \cdot \mathrm{dm}^{-3}\right)$ & $0-25$ & $0-1,2$ & $1,3-5,0$ & $>5,0$ & \\
$\mathrm{Fe}\left(\mathrm{mg} \cdot \mathrm{dm}^{-3}\right)$ & & $0-4$ & $5-12$ & $>12$ & \\
$\mathrm{Cu}\left(\mathrm{mg} \cdot \mathrm{dm}^{-3}\right)$ & & $0-0,2$ & $0,3-0,8$ & $>0,8$ & \\
$\mathrm{Zn}\left(\mathrm{mg} \cdot \mathrm{dm}^{-3}\right)$ & & $0-0,5$ & $0,6-1,2$ & $>1,2$ & \\
$\mathrm{~B}\left(\mathrm{mg} \cdot \mathrm{dm}^{-3}\right)$ & & $0-0,20$ & $0,21-0,60$ & $>0,6$ & \\
\hline
\end{tabular}

Quadro 1 - Valores limites de fertilidade química do solo para o estado de São Paulo (IAC, 1996)

A disposição da classificação dos teores dos atributos da fertilidade mapeados (Raij et al., 1996) na mesma legenda de cada mapa permitiu a visualização do nível da fertilidade do atributo para cada classe ilustrativa da variabilidade espacial. Todas as variáveis citadas no Quadro 1 estão com a classificação em sua legenda com exceção da variável boro (B) que não teve seus valores interpolados.

Comparando-se os valores do Quadro 1 com os mapas de interpolação por krigagem das variáveis, $\mathrm{Ca}, \mathrm{Mg}, \mathrm{Mn}, \mathrm{Fe}$ e $\mathrm{Cu}$, respectivamente, Figuras 41, 43, 59, 61, 63, pode-se notar que o nível de nutrientes é alto e também para o $\mathrm{pH} \mathrm{CaCl}_{2}$, Figura 33, indicando alta acidez do solo de acordo com os padrões de fertilidade do solo para o estado de São Paulo (Raij et al., 1996) e para as variáveis K, P, S, V\% e Zn, respectivamente Figuras 45, 47, 49, 57 e 65 é classificada de muito baixo a médio, os baixos valores desses atributos é indicativo de que esse solo não recebeu adubação de culturas anteriores nos últimos anos.

Pode-se observar que se as classes de teores mapeados da fertilidade do solo, fossem adequadas às divisões propostas por Raij et al. (1996), o mapa perderia a 
informação ilustrativa da variabilidade espacial do atributo mapeado, uma vez que todas as classes mapeadas seriam dispostas num mesmo nível de fertilidade (nível baixo ou alto), o que também inviabilizaria o manejo diferenciado se este conceito fosse considerado.

Nota-se que os mapas das variáveis $\mathrm{H}+\mathrm{Al}, \mathrm{M} . \mathrm{O} ., \mathrm{Ca}, \mathrm{Mg}, \mathrm{K}, \mathrm{SB}, \mathrm{CTC}, \mathrm{V} \%$, Mn e Cu (Figuras 35, 39, 41, 43, 45, 51, 55, 57, 59 e 63), sendo melhor representados pela Figura 68, possuem uma concentração de valores altos na parte mais baixa da área experimental, semelhante ao teor da variável silte (Figura 37), o que não se pôde perceber com o coeficiente de correlação de Person (Tabela 2) entre as variáveis. Diante dessas observações, resolveu-se criar a Tabela 9 com o modelo de regressão linear múltipla dos mapas interpolados para cada variável que se mostrou com uma posição de distribuição espacial de classes mapeadas semelhante e determinar o coeficiente de determinação de cada uma em relação às outras, pelo programa Idrisi32, na qual as realiza pixel a pixel. Com a interpolação dos mapas criou-se um banco de dados com “n” igual a 1.619 pontos ou pixel e cada pixel com uma dimensão de 8,28m x 8,39m para se fazer a regressão com o método passo a passo utilizado por Bakhsh (1997). 

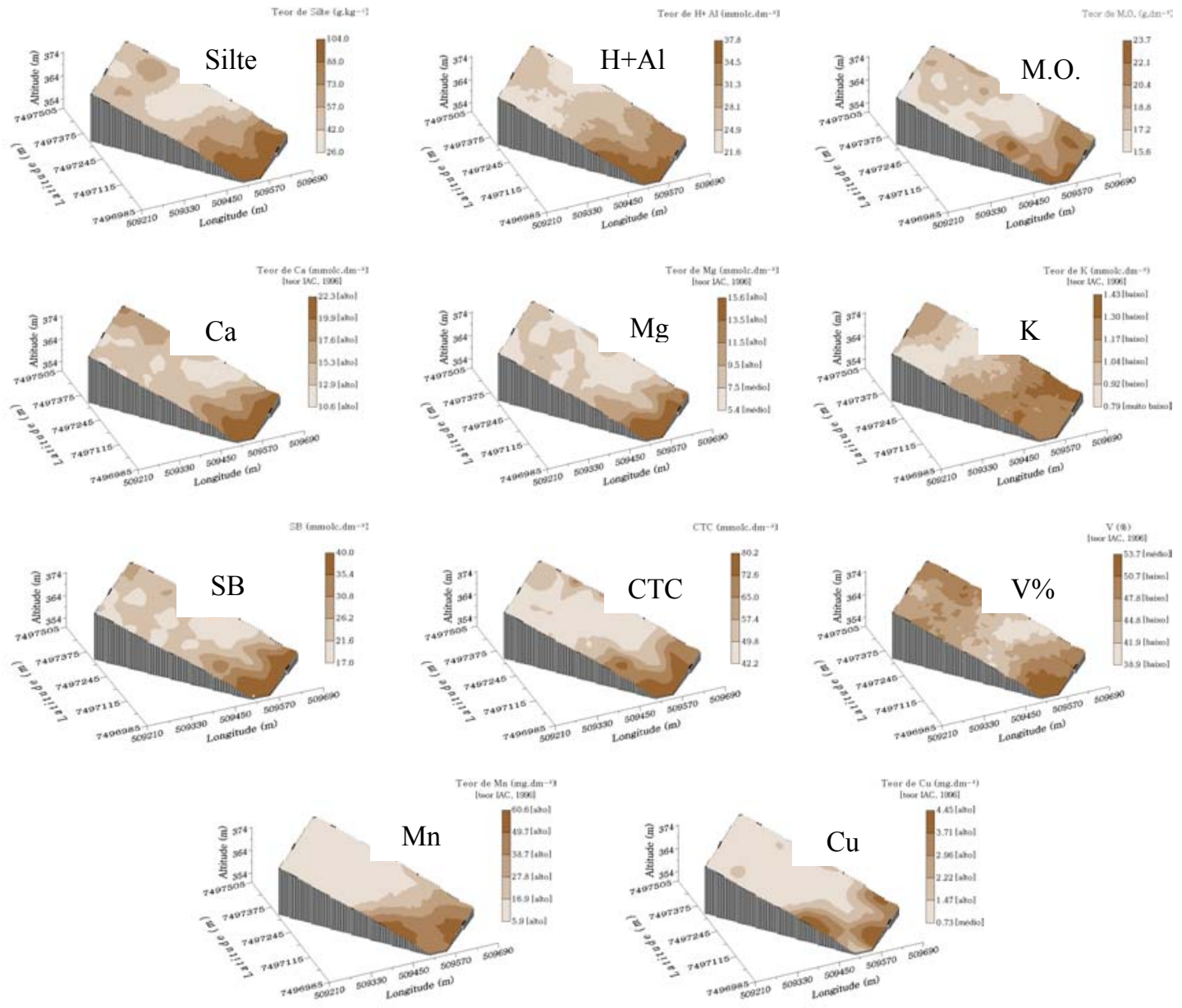

Figura 68 - Representação conjunta dos atributos do solo (silte, H+Al, M.O., Ca, Mg, K, $\mathrm{SB}, \mathrm{CTC}, \mathrm{V} \%$, Mn e $\mathrm{Cu}$ ) interpolados mostrando uma distribuição de valores altos na parte mais baixa do terreno

Tabela 9. Modelos de regressão passo a passo para as variáveis atributos do solo

\begin{tabular}{clccc}
\hline $\begin{array}{c}\text { Variáveis } \\
\text { Dependente }\end{array}$ & Modelos de Regressão (Variáveis Independente) & $\boldsymbol{r}^{\mathbf{2}}$ & $\mathbf{F}_{\text {calc. }}$ & $\mathbf{F}_{\text {tab. }}$ \\
\hline Silte $=$ & $-149,356+2,396 \mathrm{H}+\mathrm{Al}-0,389 \mathrm{M} . \mathrm{O} .-3,947 \mathrm{Ca}-$ & 87,9 & 1172,60 & 1172,58 \\
& $4,148 \mathrm{Mg}+5,846 \mathrm{~K}+3,432 \mathrm{SB}+0,037 \mathrm{CTC}+$ & & & \\
& $2,974 \mathrm{~V} \%+0,462 \mathrm{Mn}-0,132 \mathrm{Cu}$ & & \\
$\mathrm{H}+\mathrm{Al}=$ & $26,787+0,285 \mathrm{M} . \mathrm{O}+0,202 \mathrm{Ca}+1,098 \mathrm{Mg}+$ & 96,0 & 3947,30 & 3917,80 \\
& $4,563 \mathrm{~K}-0,443 \mathrm{SB}+0,054 \mathrm{CTC}-0,361 \mathrm{~V} \%+$ & & \\
& $0,116 \mathrm{Mn}-0,424 \mathrm{Cu}+0,029 \mathrm{Silte}$ & & \\
M.O. $=$ & $1,899+0,186 \mathrm{H}+\mathrm{Al}-0,160 \mathrm{Ca}-0,375 \mathrm{Mg}-$ & 89,2 & 1351,58 & 1340,31 \\
& $0,828 \mathrm{~K}+0,194 \mathrm{SB}+0,150 \mathrm{CTC}+0,112 \mathrm{~V} \%-$ & & \\
& $0,026 \mathrm{Mn}+0,271 \mathrm{Cu}-0,003 \mathrm{Silte}$ & & &
\end{tabular}


Tabela 9. Modelos de regressão passo a passo para as variáveis atributos do solo

\begin{tabular}{|c|c|c|c|c|c|}
\hline $\begin{array}{c}\text { Variáveis } \\
\text { Dependente }\end{array}$ & & Modelos de Regressão (Variáveis Independente) & $r^{2}$ & $\mathbf{F}_{\text {calc. }}$ & $\mathbf{F}_{\text {tab. }}$ \\
\hline $\mathrm{Ca}$ & $=$ & $\begin{array}{l}-5,225+0,027 \mathrm{H}+\mathrm{Al}-0,032 \mathrm{M} . \mathrm{O} .-0,604 \mathrm{Mg}+ \\
0,438 \mathrm{~K}+0,646 \mathrm{SB}-0,012 \mathrm{CTC}+0,197 \mathrm{~V} \%+ \\
0,015 \mathrm{Mn}+0,133 \mathrm{Cu}-0,006 \text { Silte }\end{array}$ & 99,0 & 16105,12 & 15331,97 \\
\hline $\mathrm{Mg}$ & $=$ & $\begin{array}{l}-8,001+0,188 \mathrm{H}+\mathrm{Al}-0,099 \mathrm{M} . \mathrm{O} .-0,784 \mathrm{Ca}- \\
0,836 \mathrm{~K}+0,710 \mathrm{SB}-0,017 \mathrm{CTC}+0,199 \mathrm{~V} \%- \\
0,006 \mathrm{Mn}+0,261 \mathrm{Cu}-0,009 \text { Silte }\end{array}$ & 98,3 & 9121,36 & 9103,86 \\
\hline K & $=$ & $\begin{array}{l}0,495+0,040 \mathrm{H}+\mathrm{Al}-0,011 \mathrm{M} . \mathrm{O} .+0,029 \mathrm{Ca}- \\
0,043 \mathrm{Mg}+0,009 \mathrm{SB}-0,002 \mathrm{CTC}-0,011 \mathrm{~V} \%- \\
0,000 \mathrm{Mn}-0,005 \mathrm{Cu}+0,001 \text { Silte }\end{array}$ & 77,2 & 547,80 & 547,39 \\
\hline SB & $=$ & $\begin{array}{l}\text { 6,493-0,113 H+Al + 0,076 M.O. + 1,249 Ca }+ \\
1,057 \mathrm{Mg}+0,264 \mathrm{~K}+0,045 \mathrm{CTC}-0,222 \mathrm{~V} \%- \\
0,009 \mathrm{Mn}-0,247 \mathrm{Cu}+0,011 \text { Silte }\end{array}$ & 99,5 & 32898,75 & 32422,06 \\
\hline CTC & $=$ & $\begin{array}{l}-9,293+0,411 \mathrm{H}+\mathrm{Al}+1,742 \mathrm{M} . \mathrm{O} .-0,685 \mathrm{Ca}- \\
0,751 \mathrm{Mg}-1,721 \mathrm{~K}+1,328 \mathrm{SB}+0,051 \mathrm{~V} \%+ \\
0,067 \mathrm{Mn}+0,692 \mathrm{Cu}+0,003 \text { Silte }\end{array}$ & 95,4 & 3337,36 & 3334,47 \\
\hline $\mathrm{V} \%$ & $=$ & $\begin{array}{l}\text { 40,498-0,547 H+Al + 0,259 M.O. + 2,249 Ca }+ \\
1,751 \mathrm{Mg}-1,976 \mathrm{~K}-1,312 \mathrm{SB}+0,010 \mathrm{CTC}- \\
0,005 \mathrm{Mn}-0,647 \mathrm{Cu}+0,055 \text { Silte }\end{array}$ & 90,6 & 1552,31 & 1552,06 \\
\hline $\mathrm{Mn}$ & $=$ & $\begin{array}{l}-55,837+2,230 \mathrm{H}+\mathrm{Al}-0,757 \mathrm{M} . \mathrm{O} .+2,163 \mathrm{Ca}- \\
0,710 \mathrm{Mg}-0,969 \mathrm{~K}-0,688 \mathrm{SB}+0,171 \mathrm{CTC}- \\
0,058 \mathrm{~V} \%+4,750 \mathrm{Cu}+0,108 \mathrm{Sil} \cdot \mathrm{te}\end{array}$ & 95,1 & 3108,93 & 3108,49 \\
\hline $\mathrm{Cu}$ & $=$ & $\begin{array}{l}-3,971-0,094 \mathrm{H}+\mathrm{Al}+0,092 \mathrm{M} . \mathrm{O} .+0,223 \mathrm{Ca}+ \\
0,337 \mathrm{Mg}-0,130 \mathrm{~K}-0,214 \mathrm{SB}+0,020 \mathrm{CTC}- \\
0,095 \mathrm{~V} \%+0,055 \mathrm{Mn}-0,000 \mathrm{Silte}\end{array}$ & 85,9 & 993,07 & 988,47 \\
\hline
\end{tabular}

Onde: $r^{2}=$ Coeficiente de determinação $(\%) ; \mathrm{F}_{\text {calc. }}=\mathrm{F}$ calculado e $\mathrm{F}_{\text {tab. }}=\mathrm{F}$ tabelado ao nível de $5 \%$ de probabilidade.

Pode-se notar na Tabela 9 que as variáveis silte, $\mathrm{H}+\mathrm{AL}, \mathrm{M} . \mathrm{O} ., \mathrm{Ca}, \mathrm{Mg}$, $\mathrm{SB}, \mathrm{CTC}, \mathrm{V} \%$, Mn e $\mathrm{Cu}$ estão com um ajustamento sempre maior que $85 \%$, o que é classificado como um ótimo ajustamento segundo Vanni, 1998 e com um F calculado sempre maior que o F tabelado, indicando que os dados obedecem ao modelo de análise de regressão linear múltipla, ou seja, que as variáveis independentes reduzem significativamente a variação da variável dependente e que apenas a variável $\mathrm{K}$ esta com um ajustamento classificado como bom (77,2\%) segundo Vanni, 1998 e com F calculado maior que o F tabelado, mostrando a existência de correlação espacial entre as variáveis. 


\section{CONCLUSÕES}

A metodologia utilizada para marcação do "grid" de amostragem mostrou-se muito demorada, podendo-se, em um próximo trabalho semelhante a este, utilizar outras técnicas mais rápidas e igualmente precisas.

Óleo (E.E.M.S.) e proteína (P.B.M.S.) não tiveram correlações com nenhuma das 21 variáveis, nem entre si, mostrando que deve procurar outras variáveis que melhor representem a variabilidade desses valores.

Não se conseguiu um ajustamento nem mesmo regular para as variáveis óleo (\%E.E.M.S.) e proteína (\%P.B.M.S.) com os parâmetros em estudo, ficando clara a necessidade de um estudo com novas variáveis para se conseguir explicar melhor a variabilidade desses teores.

Para o espaçamento de amostragem adotado, as variáveis óleo, proteína, argila e boro não apresentaram dependência espacial.

Os melhores modelos de semivariogramas para os atributos do solo foram o esférico e o gaussiano.

A interpolação dos dados por krigagem demonstrou existir possíveis correlações entre: silte, H+Al, M.O., Ca, Mg, K, SB, CTC, V\%, Mn e Cu, por terem bem definidos os teores mais altos na parte baixa do terreno, comprovada com a análise de regressão passo a passo realizada pelo Idrisi32. 


\section{REFERÊNCIAS BIBLIOGRÁFICAS}

ACKROYD, N.; LORIMER, R. Global navigation: a GPS user's guide. 2.ed. London: Lloyd's of London Press, 1994. 196p.

ALGERBO, P.A.; THYLEN, L. Coast guard beacon system. In: EUROPEAN CONFERENCE ON PRECISION AGRICULTURE '97, 1., Warwick, 1997. Proceedings. London: BIOS Scientific Publications, 1997. p.545-550.

AQUINO, L.H.; DUARTE, G.S. Curso de estatística experimental. Lavras: Escola Superior de Agricultura de Lavras, Departamento de Ciências Exatas, 1986. 204p. ASSOCIATION OF OFFICIAL AGRICULTURAL CHEMISTS. Official methods of analysis. 14.ed. Washington, 1984. 1141p.

BAKHSH, A.; COLVIN, T.S.; JAYNES, D.B. et al. Spatial distribution of soil attributes affecting crop yield. St Joseph: ASAE, 1997. 10p. (ASAE. Paper, 971032).

BALASTREIRE, L.A. Aplicação localizada de insumos - ALI: um velho conceito novo. In: CONGRESSO BRASILEIRO DE ENGENHARIA AGRÍCOLA, 23., Campinas, 1994. Anais. Campinas: SBEA, 1994. p.248.

BALASTREIRE, L.A. Estudo de caso: uma pesquisa brasileira em agricultura de Precisão. In: SILVA, F.M. Mecanização e agricultura de precisão. Poços de Caldas: Sociedade Brasileira de Engenharia Agrícola, 1998. p.203-232.

BALASTREIRE, L.A.; BAIO, F.H.R. Avaliação da acurácia de um GPS com correção por algoritmo comparado com um sistema DGPS. In: SIMPÓSIO SOBRE AGRICULTURA DE PRECISÃO, 3., Piracicaba, 2002. Piracicaba: ESALQ, Departamento de Engenharia Rural, 2002. p. 285-288. 
BALASTREIRE, L.A.; AMARAL, J.R.; LEAL, J.C.G. et al. Determinação da variabilidade espacial dos teores de óleo e proteína de grãos de soja (Glycine Max, [L.] Merrill). In: SIMPÓSIO SOBRE AGRICULTURA DE PRECISÃO, 3., Piracicaba, 2002. Piracicaba: ESALQ, Departamento de Engenharia Rural, 2002. p.66-75.

BARRETO, A.C.; NOVAIS, R.F.; BRAGA, J.M. Determinação estatística do número de amostras simples de solo por área para avaliação de sua fertilidade. Revista Ceres, v.21, n.114, p.142-147, 1974.

BERRY, J.K. Who's minding the farm? GIS World, v.11, n.2, p.47-51,1998.

BLITZKOW, D. NAVSTAR/GPS: um desafio tornado realidade. In: SIMPÓSIO BRASILEIRO DE GEOPROCESSAMENTO, 3., São Paulo, 1995. Anais. São Paulo: USP, 1995. p.429-462.

BOARETTO, A.E.; CHITOLINA, J.C.; CRUZ, A.P. Fundamentos para a amostragem de solo. In: SIMPÓSIO SOBRE INTERPRETAÇÃO DE ANÁLISE QUÍMICA DE SOLO E PLANTA PARA FINS DE ADUBAÇÃO, Botucatu, 1988. Anais. Botucatu: UNESP, 1988. p.1-46.

BOUMA, J. From soil survey to a soil data base for precision agriculture. In: EUROPEAN CONFERENCE ON PRECISION AGRICULTURE, 1., 1997. Precision agriculture - 97. p.61-69.

BOUMA, J.; FINKE, P. A. Origin and nature of soil resource variability. In: ROBERT, P.C.; RUST, R.H.; LARSON, W.E. (Ed.). Procedures of soil specific crop management: a workshop on research and developmente issues. Madison: Soil Science Society of America, 1993. p.1-7. (Special Publications).

BURGESS, T.M.; WEBSTER, R. Optimal interpolation and isarithmic mapping of soil properties. I The semi-variogram and punctual Kriging. Journal of Soil Science, v.31, n.2, p.315-331, 1980a.

BURGESS, T.M.; WEBSTER, R. Optimal interpolation and isarithmic mapping of soil properties. II Block Kriging. Journal of Soil Science, v.31, n.2, p.333-341, 1980b.

BURROUGH, P.A. Principles of geographical information systems: methods and requirements for land use planning. Oxford: Clarendon Press, 1986. 194p. 
BURROUGH, P.A.; McDONNELL, R.A. Principles of geographical information systems. New York: Oxford University Press, 1998. 333p.

BURROUGH, P.A.; VAREKAMP C.; SKIDMORE, A.K. Using public domain geoestatistical and GIS software for spatial interpolation. Photogrammetric Enginnering \& Remote Sensing, v.62, n.7, p.845-854, 1996.

CAMARGO, E.C.G. Desenvolvimento, implementação e teste de procedimentos geoestatísticos (krigeagem) no sistema de processamento de informações georreferenciais (SPRING). São José dos Campos, 1997. 105p. Dissertação (Mestrado) - Instituto Nacional de Pesquisas Espaciais.

CAMARGO, O.A de; MONIZ, A.C.; JORGE, J.A. et al. Métodos de análise química, mineralógica e física de solos do Instituto Agronômico de Campinas. Campinas: Instituto Agronômico de Campinas, 1986. 94p. (IAC. Boletim Técnico, 106).

CAMBARDELLA, C.A.; MOORMAN, T.B.; NOVAK, J.M. et al. Field-scale variability of soil properties in Central Iowa Soils. Soil Science Society of America Journal, v.58, p.1501-1511. 1994.

CARVALHO, N.M. de; NAKAGAWA J. Sementes: ciência, tecnologia e produção. 4.ed. Jaboticabal: FUNEP, 2000. 588p.

CENTRO AUSTRALIANO PARA AGRICULTURA DE PRECISÃO. Towards environmentally and economically sustainable agriculture. http://www.usyd.edu.au/su/agric/acpa/intro.htm. (10 fev. 1997).

CHITOLINA, J.C. Contribuição de alguns fatores nos resultados da análise química de terra e seus efeitos nas recomendações de adubação e calagem. Piracicaba, 1982. 200p. Tese (Doutorado) - Escola Superior de Agricultura "Luiz de Queiroz", Universidade de São Paulo.

CHItOlinA, J.C.; GLÓRIA, N.A. da; LAVORENTI, A. A representatividade de amostras de terra. Piracicaba: ESALQ, Departamento de Química, 1995. 20p.

CLINE, M.G. Principles of soil sampling. Soil science, v.58, p.275-288. 1944.

CORÁ, J.E. The potencial for site-specific management of soil and corn vield variability induced by tillage. East Lansing, 1997. 104p. Thesis (Ph.D.) - Michigan State University. 
CORÁ, J.E.; MARQUES JÚNIOR, J. Atributos do solo para agricultura de precisão. In: CONGRESSO BRASILEIRO DE ENGENHARIA AGRíCOLA, 27., Poços de Caldas, 1998. Poços de Caldas: SBEA, 1998. p.31-70.

COSTA NETO, P.L.O. Estatística. 18.ed. São Paulo: Edgard Blucher. 1977. 264p.

CRESSIE, N. Statistics for spatial data. New York: John Wiley, 1991. 900p.

DELFINER, P.; DELHOMME, J.P. Optimum interpolation by Kriging. In: DAVIS, J.C.; McCULLAGH, M.J. (Ed.). Display and analysis of spatial data. New York: John Wiley, 1975. p.96-114.

DEUTSCH, C.V.; JOURNEL, A.G. GSLIB: Geostatistical Software Library and user's guide. New York: Oxford University Press, 1992. 339p.

DUNN, R.F. Do the math. http://www.precisionag.com/math.html. (15 mar. 1998).

EASTMAN, J.R. Idrisi manual. Massachusetts: Clark University, Graduate School of Geography, 1993.

EMERSON, J.D.; STRENIO, J. Análise exploratória de dados: técnicas robustas; um guia. Lisboa: Ed. Salamandra. 1983.

ENGLUND, E.; SPARKS, A. GeoEAS (Geostatistical Environmental Assessment Software). Las Vegas: U.S. Environmental Protecy Agency, 1991. 1v. (EPA/600/488/033a).

FANHA, A.B. Caracterização de reservatórios através de técnicas estatísticas multivariadas e modelagem estocástica no campo de baixa do algodão, Bacia Potiguar. Campinas, 1994. 178p. Dissertação (Mestrado) - Instituto de Geociências, Universidade Estadual de Campinas.

FRAISSE, C.W. Agricultura de Precisão: a tecnologia de GIS/GPS chega às fazendas. Fator GIS, v.5, n.21, p.28-31, 1997.

FRAISSE, C.W. A tecnologia de GIS/GPS chega às fazendas. Fator GIS, v.21, n.1, p.28-31, 1998. 
GARCIA, A.G. Variabilidade espacial de atributos físicos do solo e resposta espectral da cultura de feijão irrigado, em imagens aéreas digitais. Piracicaba, 1997. 78p. Dissertação (Mestrado) - Escola Superior de Agricultura "Luiz de Queiroz", Universidade de São Paulo.

GOLDEN SOFTWARE. Surfer for windows: user's guide. Golden, 1995. 1v.

GONÇALVES, A.C.A.; FOLEGATTI, M.V.; VIEIRA, S.R. Padrões de amostragem e intensidade de krigagem na caracterização do armazenamento de água no solo, em área irrigada por pivô central. Revista Brasileira da Ciência do Solo, v.23, p.485495, jul./set. 1999.

GREER, J.D. The view from above. Journal of Forestry, v.91, n.8, p.10-14, 1993.

GRIGG, N.S. Water resources management: principles, regulations and cases. New York: McGraw-Hill, 1996. 540p.

GUIMARÃES, E.C. Variabilidade espacial da umidade e da densidade do solo em um latossolo roxo. Campinas, 1993. 138p. Dissertação (Mestrado) - Faculdade de Engenharia Agrícola, Universidade Estadual de Campinas.

HAMLETT, J.M.; HORTON, R.; CRESSIE, N.A.C. Resistance and exploratory techniques for use in semivariogram analyses. Soil Science Society of America Journal, v.50, p.868-875, 1986.

HEATH, O.C.S. A estatística na pesquisa científica. São Paulo: EDUSP, 1981. 95p.

HELMS, T.C.; ORF, J.H. Protein, oil and soy bean lines selected for increased protein. Crop Science, v.38, n.3, p.707-711, 1998.

HUIJBREGTS, C.J. Regionalized variables and quantitative analysis of spatial data. In: DAVIS, J.C.; McCUlLAGH, M.J. (Ed.). Display and analysis of spatial data. New York: John Wiley, 1975. p.38-53.

HURN, J. GPS: um guia para a próxima utilidade. Sunnyvale: Trimble Navigation, 1989. $76 \mathrm{p}$.

HYMOWITZ, T.; COLLINS, F.I.; PANCZNER, J.; WALKER, W.M. Relationship between the content of oil, protein and sugar in soybean seed. Agronomy Journal, v.64, n.5, p.613-616, 1972. 
INSTITUTO AGRONÔMICO DO PARANÁ, Amostragem de solo para análise química: plantio direto e convencional, culturas perenes, várzeas, pastagem e capineiras. Londrina, 1996. 28p. (IAPAR Circular, 90).

ISAAKS, E.H.; SRIVASTAVA, R.M. An introduction to applied geostatistics. New York: Oxford University Press, 1989. 561p.

JORGE, H.D. Amostragem do solo para análise química. Porto Velho: Embrapa, UEPAE de Porto Velho, 1986. 11p. (Circular Técnica, 8).

JOURNEL, A.G.; HUIJBREGTS, C.J. Mining geostatistics. London: Academic Press, 1978. 600p.

KIM, Y.C. Advanced geostatistics for highly skewed data. Arizona: The University of Arizona, Department of Mining and Geological Engineering, 1988.

KITANIDIS, P. K.; VOMVORIS, E.G. A geostatistical approach to the inverse problem in groundwater modeling (steady state) and one dimensional simulations. Water Resources Research, v.19, n.3, p.677-690, 1983.

KÖPPEN, W.M. Climatologia, con un studio de los climas de la tierra. México: Fondo de Cultura Económica, 1948. 478p.

LAJAUNIE, C. A geostatistical approach to air pollution modeling. In: JOURNEL, A.G.; MARECHAL, A. (Ed.). Geostatistics for natural resources characterization. 1984. p.877-891.

LAMOND, R.E.; WESLEY, T.L. In-season fertilization for high yield soybean production. Better Crops with Plant Food, v.85, n.2, p.67, 2001.

LAMPARELLI, R.A.C.; ROCHA, J.V.; BORGHI, E. Geoprocessamento e agricultura de precisão: fundamentos e aplicações. Guaíba: Agropecuária, 2001. 118p.

LANDIM, P.M.B. Análise estatística de dados geológicos. São Paulo: FUNEP, 1998. 226p.

LANE, N.; MONEY, A.L.; BACKER, J. et al. Press briefing May 1, 2000. http://www.whitehouse.gov/library/briefing/cgi?data-\&briefing-2. (10 jun. 2000).

LANGDALE, G.W.; SHRADER, W.D. Soil erosion effects on soil productivity of cultivated cropland. In: SCHMIDT, B.L. (Ed.). Determinants of soil loss tolerance. Madison. ASA Meeting Presentation, 1982. p.95-111. 
LANGE, A.F. On datums and geoids. GIS World, v.9, n.10, p.62, Oct. 1996.

LECHNER, W.; BAUMANN, S. Global navigations satellites systems. Computers and Electronics in Agriculture, v.25, p.67-85, 2000.

LIBARDI, P.L.; MANFRON, P.A.; MORAES, S.O. et al. Variabilidade da umidade gravimétrica de um solo hidromórfico. Revista Brasileira da Ciência do Solo, v.20, p.1-12, jan./fev. 1996.

LIBARDI, P.L.; PREVEDELlO, C.L.; PAULETTO, E.A. et al. Variabilidade espacial da umidade, textura e densidade de partículas ao longo de uma transeção. Revista Brasileira da Ciência do Solo, v.10, p.85-90, 1986.

LONG, D.S.; CARLSON, G.R.; ENGEL R.E. Grain protein mapping for precision management of dryland wheat. In: INTERNATIONAL CONFERENCE, St. Paul, 1998. Proceedings. p.787-796.

MALAVOLTA, E. ABC da análise de solos e folhas: amostragem, interpretação e sugestões de adubação. São Paulo: Agronômica Ceres, 1992, 124p.

MANTOVANI, E.C; QUEIROZ, D.M; DIAS, G.P. Máquinas e operações utilizadas na Agricultura de Precisão. In: SILVA, F.M. Mecanização e agricultura de precisão. Poços de Caldas: SBEA, 1998. p.109-157.

MATHERON, G. Principles of geoestatistics. Economic Geology, v.58, p.1246-1266, 1963.

MILLER, M.P.; SINGER, M.J.; NIELSEN, D.R. Spatial variability of wheat yield and soil properties on complex hills. Soil Science Society of America Journal, v.52, p.1133-1141, 1988.

MIRANDA, L.N. de. Amostragem de solo para análise química. Brasília: Embrapa, CPAC, 1982. 15p. (Circular Técnica, 11).

MORETTIN, P.A.; BUSSAB, W.O. Estatística básica. 4.ed. São Paulo: Ed. Atual, 1987. 321p.

MULLA, D.J. Geoestatistics, remote sensing and precision farming. In: Precision agriculture 1997: spatial and temporal variability of environmental quality. Chichester: Wiley, 1997. p.100-119. (Ciba Foundation Symposium, 210). 
MULLA, D.J.; SCHEPERS, J.S. Key processes and properties for site-specific soil and crop management. In: PIERCE, F.J.; SADLER, E.J. (Ed.). The state of site specific management for agriculture. Madison: ASA; CSSA; SSSA, 1987. p.1-18.

OLIVEIRA, J.B. Variação de características morfológicas, físicas, químicas e mineralógicas em duas áreas de oxissolo. Piracicaba, 1972. 199p. Tese (Doutorado) Escola Superior de Agricultura “Luiz de Queiroz”, Universidade de São Paulo.

OLIVER, M.A.; WEBSTER, R. Kriging: a method of interpolation for geographical information systems. International Journal of Geographical Information System, v.4, n.3, p.313-332, 1990.

OPENSHAW, S. Developments in geographical information systems. Economic and Social Research Council, v.63, p.11-14, 1988.

PAZ, A.; TABOADA, M.T.; GÓMEZ, M.J. Spatial variabilility in topsoil micronutients contents in one-hectare cropland plot. Comunications in Soil Science and Plant Analysis, v.27, n.3/4, p.479-503, 1996.

PEARSON, E.S.; HARTLEY, H.O. Biometric tables for statisticians. New York: Cambridge University Press, 1966. 264p.

PECCOL, E.; BIRD, C.A.; BREWER, T.R. Geographic information systems (GIS) and landscape mapping: a case study. In: WORLD CONGRESS AND AGENG'94 CONFERENCE ON AGRICULTURAL, 7., 1994.

PECK, T.R.; MELSTED, S.W. Field sampling for soil testing. In: WALSH, L.M.; BEACON, J.D. Soil testing and plant analysis. Madison: SSSA, 1973. p.67-75.

PRADO, H. Manual de classificação de solos do Brasil. Jaboticabal: FUNEP, 1993. $197 \mathrm{p}$.

PRESTON, D.A. Fortran IV programs for sample normality tests. Lawrence: University of Kansas, 1970. 27p. (Computer Contribution, 41)..

RAIJ, B. van; CANTARELLA, H.; QUAGGIO, J.A. et al. (Ed.). Recomendações de adubação e calagem para o Estado de São Paulo. 2.ed. Campinas: IAC, 1996. 285p. (IAC. Boletim Técnico, 100).

RAIJ, B. van; QUAGGIO, J.A.; CANTARELLA, H. et al. Análise química do solo para fins de fertilidade. Campinas: Fundação Cargill, 1987. 170p. 
RAIJ, B. van; SILVA, N.M. da; BATAGLIA, O.C. et al. Recomendações de adubação e calagem para o Estado de São Paulo. Campinas: Instituto Agronômico, 1985. 107p. (IAC. Boletim Técnico, 100).

REICHARDT, K.; VIEIRA, S.R.; LIBARDI, P.L. Variabilidade espacial de solos e experimentação de campo. Revista Brasileira da Ciência do Solo, v.10, p.1-6, 1986.

RODRIGUES, B.N.; ALMEIDA, F.S. Guia de herbicidas. 4.ed. Londrina: Os autores, 1998. 647p.

SALVIANO, A.A.C. Variabilidade de atributos de solo e de crotalaria juncea L. em solo degradado do município de Piracicaba-SP. Piracicaba, 1996. 83p. Tese (Doutorado) Escola Superior de Agricultura “Luiz de Queiroz”, Universidade de São Paulo.

SALVIANO, A.A.C.; VIEIRA, S.R.; SPAROVEK, G. Variabilidade espacial de atributos de solo e de Crotalaria juncea L. em área severamente erodidas. Revista Brasileira da Ciência do Solo, v.22, p.115-122, 1998.

SARAIVA, O.F. Amostragem de solo para avaliação de sua fertilidade: curso de pecuária leiteira. Coronel Pacheco: Embrapa, CNPGL, 1989. 8p. (Embrapa CNPGL. Documentos, 38).

SEBER, G.A.F. Linear regression analysis. New York: John Wiley, 1977. 475p.

SCHMIDT, M.J. Understanding and using statistics basic concepts. Lexington: D.C. Heath and Company, 1975. cap.6, p.131-157: Correlation: measuring relations.

SHAPIRO, S.S.; WILK, M.B. An analysis of variance test for normality (complete samples). Biometrika, v.52, p.591-611, 1965.

SILVA, A.B. Sistemas de informações geo-referenciadas: conceitos e fundamentos. Campinas: UNICAMP, 1999. 236p.

SOKAL, R.R.; ROHLF, F.J. Biometry. San Francisco: Freeman, 1969.

SOUZA, D.M.G.; MIRANDA, L.N.; LOBATO, E. et al. Métodos para determinar as necessidades de calagem em solos dos cerrados. Revista Brasileira da Ciência do Solo, v.13, p.193-198, 1989. 
SOUZA, L.S. Variabilidade espacial do solo em sistemas de manejo. Porto Alegre, 1992. 162p. Tese (Doutorado) - Faculdade de Agronomia, Universidade Federal do Rio Grande do Sul.

STURARO, J.R. Mapeamento geoestatístico de propriedades geológico-geotécnicas obtidas de sondagens de simples reconhecimento. São Carlos, 1993. 146p. Tese (Doutorado) - Escola de Engenharia de São Carlos, Universidade de São Paulo.

TOMÉ JÚNIOR, J.B. Manual para interpretação de análise de solo. Guaíba: Agropecuária, 1997. 247p.

TRANGMAR, B.B.; YOST, R.S.; UEHARA, U. Application of geostatistics to spatial studies of soil properties. Advances in Agronomy. v.38, p.45-94, 1985.

TRANGMAR, B.B.; YOST, R.S.; WADE, M.K. et al. Spatial variation of soil properties and rice yield on recently cleared land. Soil Science Society of America Journal, v.51, p.668-674, 1987.

VANNI, S.M. Modelos de regressão: estatística aplicada. São Paulo: Legmar Informática \& Editora, 1998. 177p.

VIEIRA, S.R. Uso da geoestatística em estudos de variabilidade espacial. In: CURSO DE ATUAliZAÇÃO EM CONSERVAÇÃO DE SOLO, Campinas, 1995. Apostila. Campinas: IAC, 1995. 61p.

VIEIRA, S.R. Geoestatística aplicada a agricultura de precisão. In: BORÉM, A.; GIÚDICE, M.P. del.; QUEIROZ, D.M. de. et al. (Ed.). Agricultura de precisão. Viçosa: UFV, 2000. cap.5, p.93-108.

VIEIRA, S.R.; LOMBARDI, D.R.; BURROWS, I. Mapeamento das precipitações máximas prováveis para o Estado de São Paulo. Revista Brasileira da Ciência do Solo, v.1, p.93-98, 1991.

VIEIRA, S.R.; NIELSEN, D.R.; BIGGAR, J.W. Spatial variability of field-measured infiltration rate. Soil Science Society of America Journal, v.45, p.1040-1048, 1981.

VIEIRA, S.R.; DE MARIA, I.C.; CASTRO, O.M. et al. Utilização de análise de Fourier no estudo do efeito residual da adubação em uva na crotalária. Revista Brasileira da Ciência do Solo, v.11, p.7-10, 1987. 
VIEIRA, S.R.; HATFIELD, J.L.; NIELSEN, D.R. et al. Geostatistical theory and application to variabilitty of some agronomical properties. Hilgardia, v.51, n.3, p.175. 1983.

VIEIRA, S.R.; TILLOTSON, P.M.; BIGGAR, J.W. et al. Scaling of semivariograms and the kriging estimation of field-measured properties. Revista Brasileira da Ciência do Solo, v.21, p.525-533, 1997.

WINKLER, V.J.; FRITZ, C.N.; GRAUSGRUBER. H. et al. Spatial field variations in soy bean (Glycine max [L.] Merr.) performance trials affect agronomic characters and seed composition. European Journal of Agronomy, v.12, n.1, p.13-22, 2000.

YANAI, J.; LEE, C.K.; KAHO, T. et al. Geostatistical analysis of soil chemical properties and rice yield in a paddy field and application to the analysis of yielddetermining factors. Soil Science and Plant Nutrition, v.47, n.2, p.291-301, 2001. 